LIRPARY

OF THE

UNIVERSITY OF ILLINOIS 



\section{THE INFLUENCE OF TEMPERATURE AND CONCENTRATION ON THE TOXICITY OF SALTS TO FISH}

BY

EDWIN BOOTH POWERS

A. B. Trinity University, 1906.

M. S. University of Chicago, 1913.

THESIS

Submitted in Partial Fulfillment of the Requirements for the

Degree of

DOCTOR OF PHILOSOPHY

IN ZOOLOGY

IN

THE GRADUATE SCHOOL

OF THE

UNIVERSITY OF ILLINOIS 



\section{UNIVERSITY OF ILLINOIS}

THE GRADUATE SCHOOL

I HEREBY RECOMMEND THAT THE THESIS PREPARED UNDER MY SUPERVISION BY_Edwin Rooth Powers.

\section{ENTITLED TIE INFLUENCE OF TRMPRATURE AND CONCTNTRATION}

\section{ON THE TOXICITY OF SALTS TO FISII.}

BE ACCEPTED AS FULFILLING THIS PART OF THE REQUIREMENTS FOR THE DEGREE OF_DOCTOR OF PHILOSOPIY IN ZOOUUGY.

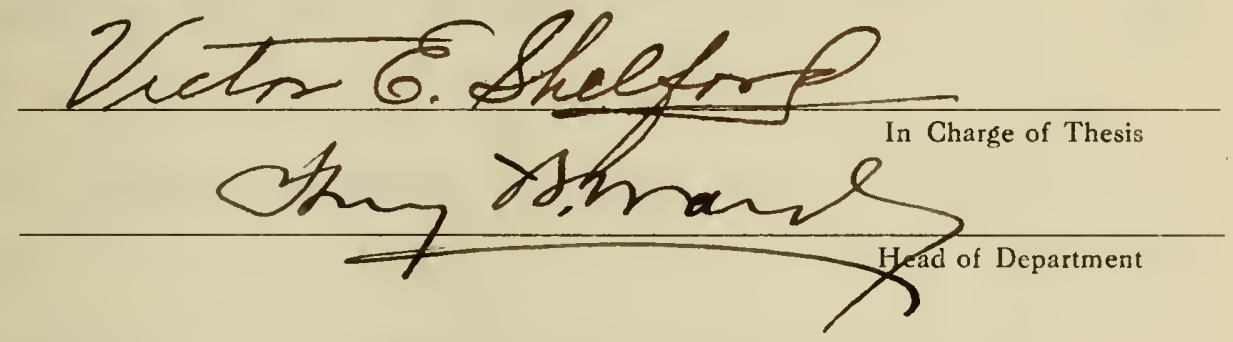

Recommendation concurred in*

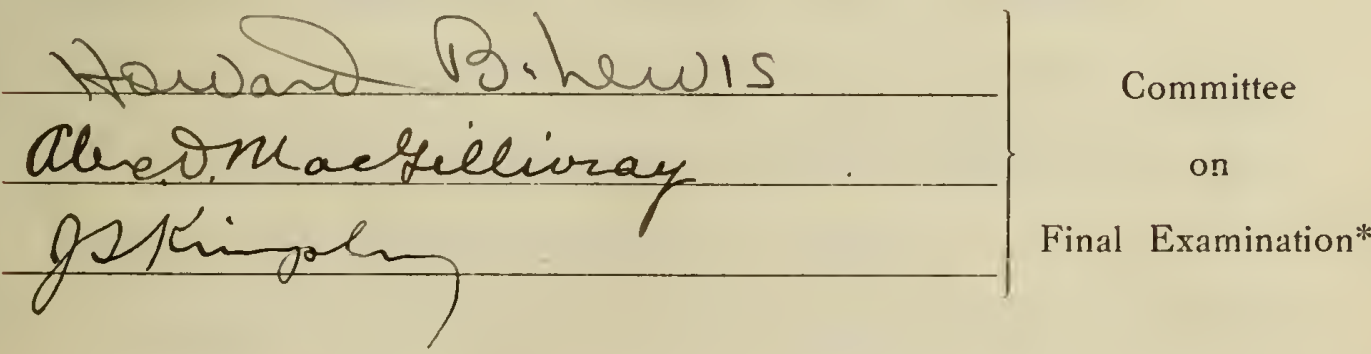



TABLE OF CONTLNTS

I Introduction $\ldots \ldots \ldots+\ldots \ldots$

II Methods and Material _ $\ldots \ldots \ldots+\ldots$

III Experiuental Data $\ldots \ldots \ldots \ldots$

IV Toxicity and the Measurenient of Toxicity -

$V$ The Effect of Temperature on the Toxicity of Deletericus Substancos to Fish $\ldots+\ldots+\ldots$

a. The Effect of Tcmperature on the Toxicity of Lithium chloride to Goldfish _ . . . . 12

b. The Effect of Temperature on the Toxicity of Sodium Chloride, Magnesium Chloride, Colcium

Chloride, and Barium ChIoride to Fish _ . - 15

c. The Effect of Temperature on the Toxicily of Amonium ChIoride to Fish. _ $\ldots \ldots+\ldots$

d. The Relation of the Erfect of Temperature on the Toxicity of Salts to Fish and van't Hoff's

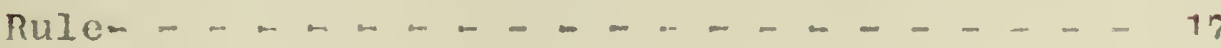

VI A Comparison of the Temperature Toxicily Curve to the Temperature Mctabolism and the Temperature Standard Metabolism Curves of Otler Workers- - - 24

VII A Method of Measuring Relative Resistances of Fish to Deletcrious Substances and the Camparative Pesistance of Certain species of Fish $-\ldots+\ldots$ VII A Comparison of the neistive Toxicilies of Certain of the Environmental salts and their Flectrical 

IX Antagonism and its Possible ttility in Natural Polluted.

Pagc iraters - - - - - - - - - - - - - - 35

$\mathrm{X}$ General Discussion - $\ldots \ldots \ldots+\ldots \ldots$

XI Sumary of Conclusions - $\ldots+\ldots+\ldots$

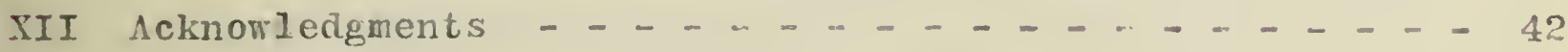

XIII Billiogruphy - - - - - - - - - - - - - - - 43

XIV Tables - - - - - - - - - - - - $-\ldots 1$

$\mathrm{XV}$ Figures $-\ldots-\ldots-\ldots-\ldots-\ldots$ XVI Vita $-\ldots-\ldots-\ldots-\ldots, \ldots-\ldots$ 
Digitized by the Internet Archive in 2014 


\section{INTRODUCTION}

In previous work on the toxicities of ceratin substances to goldfish, the writer found that their physiological activities with few exceptions follow a general. law. The following investigation was undertaken to determine the effect of temperm ature upon this general law and to correlate this effect with the physiology of the organism. Methods for the study of the deleterious errect of environmental faclors are also suggested.

This work was carried on in the Zoological Laboralnuy of the University of Illinois under the direction of Professor Victor E. Shelford whom the writer wishes to thank for his many courtesies and helpful suggestions throughout the course nf the investigation.

\section{METHODS AND MATERIAL}

All experiments wore carried on at a temperature varying not more than a maximum of 0.2 to 0.3 of a degree centigrade. This almost uniform temperature ras made possible by the use of a Johnson thermosta i. The constant temperature apparatus consisted of an 1lbcrene stone aquarium $183 \mathrm{~cm}$. by $44.5 \mathrm{~cm}$. hy $34.5 \mathrm{~cm}$. deep outside measurcments, in which the water was 15 cm. deep into which ressels containing the solutions and fish were set. The temperature of the bath was regulated by the Johnson hot water thermostat placed at the conter. It controlled the flows of hot and cold water which entered the tank at the end opposite the outlet. The temperature of the bath was 

recoried by a Tycos recording thermometor (see Figure 1.); it was kept uniform throughout by agitating the water with small widely dispersed bubbles of air. When the flow of water was large (2 Iiters per min.) there was a variation of from 0.8 to 0.9 of a degree centigrade with three or more ascillations per ten minutes. With a very small inflow of water thesc oscillations were fewer and less in range and disappeared almost cntirely and the temperature at the center of the tank becane practically uniform (See Figure $1 \mathrm{~A}$ to $\mathrm{B}$ and $\mathrm{C}$ to $\mathrm{D}$ and for uniform tomperature see $E$ to F.). Tho difference in the temperature of the water at the two ends of the tank was very sligit as was shown by readings taken from time to time.

The fish used in the experiments were kept in ruming water at a temperature of from 18 to $20 \mathrm{C}$. The goldfish were bought of a local dealer and the wild fish were obtained from small streams near by. The mortality of the wild fish was very slight following the second day after they were brought into the Iaboratory. These fish were not used in the experiments until after the mortality of the stock had ceased and were not used after having been kept in the laboratory two or three reeks. In the experiments the fish rere tested in $1500 \mathrm{cc}$. of a solut. tioncontained in a two quart Mason jar which was kept closed with a rubber stopper. The experimental jars were kept in the constant temperature tank and the surviral time of each fish recol'ded.

Distilled water was used in all experiments. This was prepared by condensing steam from a hot water tank of reboiled water. The condenser tube was made of Jena glass tubing. The water as collected from the condenser was strongly acid due to 

the presence of an excess of carbon dioxide. After aerating with carbon dioxide free air for twenty four hours the water ras found by analysis to contain:-

Physical examination.

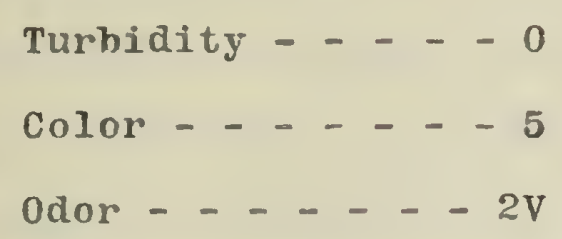

Residue on evaporation.-

Total solids - - 32 to 42 parts per milion.

Alkalinity as calcium carbonate.

Methyl orange - - 0 to 0 parts per million.

Chlorides.

As sodiun chloride- 0 to 0 parts per million.

Ammonia nitrogen _ $-\ldots$ - 4 to $\%$ parts per miliion.

Albuminoid ammonia - -0.06 to 0.102 parts per million.

This water was not rapidly fatal to fish. Two goldfish (Carassius carassius L.) Iived ninety-five and ninety-nine days and six blunt-nosed minnors (Pdmephales notatus Raf.) liver eleven, twelve, thirteen, fifteen, thirty, and thirty-two days respectfully in the distilled water. Two other bluntresed minnows jumped out of the water, one after seventeen days and the other after thirty-ihree days. The water was changed every seven days. This special water was used since it luad been found that goldfish would live only from three hundred and fifty-two to five hundred and ninety-seven minutes in ordinary distilled water (Powers 1018). 

It has been shown in previous work vith goldfish that, when an individual is killed in a toxic substance, including acids, salts, alcohols, pyridine, caffeine, and phenol, the survival time of the goldfish is not directly proportional to the concentration of the substance used, but there is a uniform deviation from this relation which is common to all substances thus far tested with the exception of the chlorides of some of the heavier metals. Experiments were run with goldfish with lithium chloride and the blunt-nosed minnow and the straw-colorm cd minnow (Notropis blennius Gir.) with the chlorictes of ammoniun, sodium, magnesium, calcium, and barium to determine the effect of temperature upon the toxicities of these salts. From these experiments it was hoped $\imath$ o determine the effect of temperature upon the deleterious results of any toxic substance which might appear in the habitat of the fish either as a natural environmental factor or as a contamination.

Experiments were run with the goldfish to determine the relatire toxic actirities of lithium chloride at $4^{\circ}, 11.8^{0}, 15.3^{\circ}$ $20^{\circ}, 24.9^{\circ}, 29.8^{\circ}$, and $34.8^{\circ} \mathrm{C}$. The results of these experiments are given in Table I. In all tables the velocity of fatality which represents the rapidity with which the fish were kilied 1s the reciprocal of the surviral time. One hundred over the survival time is used instead of one over the survival time to avoid the use of fractions. The relative conductance ras determined with a Hashburn conductivity cell modifled especially for this work and a wheatstone bridge. A telephone receirer 

with a fundamental vibration of 1000 per second was used instead of a galvanometer. The alternating current was generated by a small Leeds and Northrup high frequency generator driven hy two storage batterics and regulated to produce 1000 alternations per second. Table II gives the ratio of increase in toxicity of the lithium chloride at concentrations from $0.046 \mathrm{~N}$. to $0.488 \mathrm{~N}$. for an increase of approximately ten degrees centigrade as measured by the actual survival time of the fish in any one concentration at the two temperatures. Tables III to VI give the surrival time and the relocity of fatality of the blunt-núsed minnow in different concentrations of sodiurn chloride, magnesium chloride, calcium chloride, and barium chloride at $12.8^{\circ}, 17.8^{\circ}, 22.8^{\circ}, 27.8^{\circ}$, and $32.8^{\circ} \mathrm{C}$. The relative conductance is given in column five of the tables for each of the salts at the different temperatures. Table VII gives the ratio of increase in toxicity of the different concentrations of each of the four salts tested.for an approxinate rise of ten degrecs centigrade. Table VIII is a summary of the relative conductance of sodium chloriae, magnesium chloride, calcium chloride, and barium chloride for comparison. Tables Ix and XIT give the surrival time and the velocity of fatality of the bluntnosed minnow and the straw-colored minnow in different concentrations of ammonium chloride. Tables XVIII and XIX show the antagonism of calcium chloride to sodium chloride and vice versa. All figures are graphic renresentations of data given the tables. $V$ In all cases the circles $(\cdot)$ and the plus signs $(t)$ represent actual experimental data or calculations made from actual cx- 

nerimental data.

\section{TOXICITY AND TIE MEASURENENT OF TONICITY}

Toxicjty has been variously derined by different workers. A common definition is tlat any agent which, when introduced into the animal organism, is capable of producing a morbid, noxous, or deadly effect upon it, is said to be toxic. For the purpose of this paper toxicity will be taken to mean the effect of any agent which occurs in the habitat of the fish either as a natural environmental factor or as a pollution, the presence of which causes the death of the fish or interfears adversely in any way with its reproduction, development, or growth. Up to the present hut very little work las been done in determining in a quantitative way the toxicity of naturally occuring and pollution substances. Shelford (1917) has determined the toxicities of a number of the coal tars and the coal tar wastes to certain species of fish by using the one hour surviral time as a criterion. Wells has made a quantitative study of a number of species of fish to carion dioxide, lack of oxygen (1913), salts (1915a), and carbon monoxide (1918).

On a previous occasion experiments were performed to determine the efficiency of the goldfish as a test animal in physiological assay work (Powers 1918). In this work it was found that the toxic activity of a substance hares a very definite relation to its concentration. It was found that as the concentration of a substance was increased, beginning with a very dilute solution, a concentration was found that would just kill the rish. This concentration was designated as the threshold of toxicity concentration. Is the concentration was incrcased 

from this point the relocity of fatality, which is the reciprow cal of the survival time, increased at first very slowly. This was followed by a more rapid increase and in turn, at higher concentrations, by a less rapid increase. There is evidence that at still higher concentralions there was again a more rapid increase in velocity of fatality. In other wolds the ratin of increase in toxicity with a given increase in concentration of a solution as measured by the survival time of the fish decreases as the concentration is increased. This decrease in the ratio of increase in toxicity for my given increase in the concentration of the substance tested is more than sufficient to allow for a constant ratio of increase in toxicitr for a given per cent of increase in concentration of the toxic substance. Thus a sigmoid curre is formed when the relocity of ratality is plottcd as ordinate and the concentration of the substance tested is plottca as abscissa. See curre,CABG, Figure 2. This curve is taken as a representatire of the typical form of curve given by all substances tested both in tiris and subsequent work with the exceptions of cupric chloride, cadmium chloride, and ferric chloriac. The deviation of the velocity of fatality curves of these three salts from the normal, was explained in a nrevious rotk (porers 1918). From a study of the curve CABG, FIgure 2, it is seen at very low concentrations $(0.0055$ Y. to $0.027 \%$.$) of the ammonium chloride, i.e., c to 1$ of the curve, the velocity of ralality curve rises very slowly with increase in concentration of the ammonium chloride. This is scen more plainly by an inspection of Tables IX and rIII. Colums threc of these tables show a fall of survival time and columns 

four the increase in the velocity of fatality with increase in concentration of the ammonium chloride. The slant of the velncity of fatality curve $C A B G$, Figure 2 , shors the rapidity of the increase of the velocity of fatality with the increase in concentration of the ammonium chloride. At first the upward curvature of the relocity of fatality curve is very small as compared to the increment in concentration of the ammonium chloride. As the concentration increases there is a more rapid upward currature which finally approaches a straight line. From this portion, i.e., the portion A to B, the uprard curvature becomes less and the relocity of fatality curve becomes concare downward. When finally at very high concentrations there is again a second phase at which the uprard curvature is increased. This last point is shown in the velccity of fatality curve of the straw-colored minnow killed in ammonium chloride at $19.8^{\circ} \mathrm{C}$. (Fir.3) and TableXIII, since experiments were run over a much wider range of concentrations than in the other series of experiments. The velocity of fatality curve, Figure 3 , is a graphic representation of the data of Table XIV. From this figure it is seen that the velocity of ratality curve approximates a straight line at $0.015 \mathrm{~N}$. to $0.03 \mathrm{~N}$. This is followed by a concave downward curvature from $0.03 \mathrm{~N}$. to about $0.05 \mathrm{~N}$. which is final] followed by a concave upward curvature from about $0.05 \mathrm{~N}$, to $0.6 \mathrm{~N}$. This last point has not been proven for all substances tested but there is evidence that it holds good for all substances that follow this same general law as these two curves are compare to the curves of all toxic substances tested with fish 

with the excention of the chlorides of certain of the heavier metals and conforms very strikingly with the equation, $\frac{1}{t}=$ $Y=\frac{M K_{2}+K_{1} X}{\left.\log _{e}\left(\frac{M}{M-Z}+\frac{K 2 M z}{K_{1}(M-2}\right) \cdot \frac{1}{X}\right)}$, which was formulated from the theory of toxicity and when plotted gives a similar curve.

It is interesting on connection with this theory of toxicity that Hewitt (1907) and others have suggested that anaesthesia is due to the lowering of the oxygen consumption. The cause of this lowering of the oxygen consumption has been variously explained by different workers. Burge (1917) has shown that the catalase of the blood of the dog and cat is lowered as the oxyconsumption gen ${ }_{\wedge}$ is lowered. Burge, Neill, and Ashman have also shown (1918) that the catalase is both destroyed in the blood and that"its formation is inhibited by certain anaesthetics including chlnroform, ether, and magnesium sulphate. The above equation was an attempt at an expression of the rate at which this combined action or similar combined actions of other protoplasmic poisons takes place. The expression is the result of the combination of two equations which represent the two actions which are taking place in the body of the animal. 1. the equation $\frac{d z}{d t}=K_{1} z(M-z)$ was taken to ropresent the speed at which the rate of metabolism is reduced by the inhibition of the formation of some essential metabolic product. $M=$ rate of metabolism or the rate at wich any essential metabolic product is formed. $z=$ the amount of reduction of the rate of metabolism or the amount of the reduction of the rate of formation of any essential metabolic product. $\mathrm{K}_{1}=$ a constant which represents the efficiency of the 

reduced rate of metabolism in inhibitivg metabolic processes or the efficiency of the reduced rate of the formation of any essential metabolic product in further slowing the rate of production of the essential metabolic product by slowing the rate of metabolic processes. Rahn (1916) has suggested that the enzymes of the cell are formed and destroyed probably at the same rate thus keeping the total amount of enzyme in the cell constant. This of course would be true only when the metabolic processes are uniform over a period of time. This is probably true of other essential metabolic products. Thus $M$ would then represent the total amount of any essential metabolic product under normal and unfform conditions. For example with an animal killed with an anaesthetic such as chloroform, ether, or magnesium sulphate M would represent the total amount of catalase in the blood of an animal under normal conditions. $z$ would represent the amount of catalase reduced by lowering the rate of production of catalase by the tissues of the animal which is brouglit about by the slowing down of the metabolic processes, i.e., it is autolytic. 2. The equation $\frac{d z}{d t}=\mathbb{K}_{1} X(M I-z)$ was taken to represent the speed of inhibiting the rate of metabolism or the rate of the destruclion of the essential metabolic product present in the body of the organism. $x=$ the protoplasmic poison. $K_{1}=$ the efficiency of the protoplasmic poison in reducing the rate of metabolism or in destroying the essential metabolic product. With an animal anaesthetized with chloroform, ether, or magnesium the equation would represent the rate of destruction of the catalase already present in the blood of the animal. When these two equations 

which represent the two actions which are taking place simultaneously are combined and integrated it gives the Expression which was taken as representing the rate of fatality of protoplismic.

In all the relocity of fatality curves studied there is a portion ( 1 to B, Figure 2.) which approaches a straiglit linc, and in a criterion for lhe measure of toxicity can be considered as a straitht line. AB when extended as a straight line cuts the $\mathbf{x}$-axis at the point $P$. The concentration of ammonim chloride represcnted on the scalc of the graph by the point p has been designated as the theoretical threshold of toxicity concentration. And the line PABF has been desigrated as the theoretical velocity of fatality curve. This the slope of the theorctical velocity of fatality curve or the angle $\theta$ (Figure 2.) can be taken to represent the rapidity with which the rate of velocity of ratality increases with the increase in the concentration of the toxic substance. The theoretical threshold of toxicity concentration and the rate of increase in velocity of fatality are the reciprocal of each other, i.e., as the theoretical toxicity concentration increases the toxic activity of the substance can be said to decrease. And when the rate of increase of velocity of fatality increascs the toxlc activity can be said to increase. An expression, $T($ toxicity $)=\sqrt{\frac{\tan \theta}{a}}$, which takes botls these factprs into consideration has been formulated (Powers 1918) to exnross the relative toxicities of substances. Perhans a better and more simple explession for the relatire toxicity is the equation of the theoretical velocity of fatality curve itself which is the equation of a straight line. That is, $\frac{y}{x-a}=K . \quad y=$ the 

velocity of fatality. $x$ = the concentration of the solution testad. $a=$ the theoretical threshold of toxicity concentration. And $\mathbf{K}=$ a constant which can be taken to represent the relative toxicity of the substance. This equation which is more convenient than the above expression represents the same thing. The theoretical basis for the validity of the use of the equation ril! be discussed later.

The equation can be utilized to determine the relative toxicities of tro substances or it can be user in the deternination of the relative resistances of two different species of fish to injurious substances. When corrections are made for differences of temperature at which experiments are run. It is the absence of some such criterion or basis for comparison which has lead to confusion in the resuits of the determinations of the relative resistance of fish. Wells (1918) has detemined the seasonal variation in the resistance of the rock bass (Ambloplites rupestris Raf.) to Iack of oxygen apparently without taking lemperature into consideration.

THE IFTECT OF TAMPERAMURE ON THE TOXICITY OF DFIETER IOUS SUBSTANCES TO FISH

a. The Fffect of Temperature on the Toxicity of Lithilum Chlorides to Goldrish

- A series of experinents were run to detemine the effect of temperature toxic activity of lithium chloride to a one to two gram goldfish. The toxicity of the lithiun chloride was testeu at ${ }^{\circ}, 11.8^{\circ}, 15.3^{\circ}, 20^{\circ}, 24.9^{\circ}, 29.8^{\circ}$, and $31.8^{\circ} \mathrm{C}$. As is seen fron Table I the toxicity of the lithium chloride increases 

Vith a rise nf temperature. From Table IT it is seen that when the actual survival time of the goldfish or the relncity of falality is taken as a criterion for toxic activity that the ratin of increasc of toxicily for each approximate rise of ten dicgrecs contigradc gradualiy increases fron the lowest tomperature tn the highest tcmperature tested. This is mhat would be expected from the effect of temperature on biological reactions. The relation of the terperature quotient or van't Hore's rule ril? be discussed later. vhild (1913) has showr that planaria with a higler ratc or metabolism are less resistant than those with a lower rate of melaholism to toxic substances sufoicicntly strong to kill them before acclimation has had time to take place, i.e., the higher the rate of metabolism the greatcr the velocity of fatality. This is not only true in the casc of Planaria but it has been found generally true of fish. The younger (smaller) fish of a species hare been found in general to have less resism tance to toxic substances than the older (Iarger) individuals (We11s 1.913, Shelford 1917, and Powers 1918). The effect of the rolume of the fish on its resistance to toxic substances is not known. This has never been satisfactorily rorked out.

There is an increase in the velocity or fatality or the fish in toxic suhstances at higher temperatures due to the increascd rate of metabolism at the higher tomperatures. But in addition to this there should be an increase in the velncity of fatality of the fish due to the increased activity of the toxic substance itself at the higher icnperatures. Snyder (1908, 1911) has collected and sumrarized data shoring the afrect of temper- 

ature on the rate of increasc of biological reactions such as the nerve conduction of the sciatic of the frog, respiration of larvae of the dragon-riy, coagulation, etc. Loeh and Firald (1913) on the development of Fundulus embryos, Laurens (1914) on the development of Amblystoma cmbryos, Voodruff and Baitsell. (1911) on the rate of reproduction of Paramaecium, Irogh (1914, 1914a) on the rate of development of eggs and larvae of fish and frogs and the eggs and pupae of insects, Osterhout (1917) nn biological rcactions in gencral, Locb an Northrop (1917) on the influence of temperature on the length of duration of the larval, pupal, and adult stages and the total duration of life of the fruit-fly, Drosophila, and other investigators have worked along the same lines. When the data of these workers are examined It is found that the relative effect of temperature decreases from the lower temperatures to the higher temperatures. In all vital phenomena a temperature will be reached where the rate of normal metabolic reactions will be retarded instcal of increased and finally will be stopped altogether. As has been pointed out the ratio of increase of toxicity of the lithium chlnride to the gold“ish for a rise of ten degrees centigradc increascs from the lower to the higher temperatures. This is thc opposite to that of blological reactions in general. Tlis however is what would be expected. That is, the velocity of fatality increases with rise in the initlal rate of metabolism of the individual fish. Ind the relative effect of temperature in producing an increasc in the ratc of metabolism is lessened with a rise in temperature. And the effect of temperature on the chemical activity of a suh- 
stance is more nearly constant, there being only a slight retardation in the effect of the temperature at the higher temperatures. Since the toxic value of a substance is dependent both on the rate of metabolism of the fish and the activity of the substance itself it would expected that the effect of temperature on the toxicity of a deleterious substance would be the resultant of the effect on the rate of metabolism and the chemical activity of the substance itself. This is what has actually been found in the case of the effect of temperature on the velocity of ratality of goldfish when killed with lithium chloride. That is, the ratio of increase in velocity of fatality should always decrease less rapidly than the ratio of the relative effect of temperature on the rate of metabolism. And in some cases at least there should even be a rise in the ratio of the increase of the velocity of fatality. In no case would there ever be a decrease in the actual velocity of fatality at the higher temperatures as is actually the case with certain otlier biological reactions. This has been shown by Loeh and Northrop (1917) for the duration of life of the fruit-fiy and by Groves (1917) for the duration of life for seed. The same was found true by Lilie (1917) for the activation of the starfish eggs with butyrIc acid.

b. The Affect of Temperature on the Toxicity of Sodium ChInride, Magnesium Chloride, Calcium Ohloride, and Barium Chloride to Fish. Experiments were run to determine the effect of temperature on the toxicity of certain of the environmantal salts. The salts chosen for this purpose were sodium chloride, magnesium 

chloride, calcium chloride, and barium chloride. Experiments were run with very low concentrations $(0.025 \mathrm{~N}$.$) to very high$ concentrations $(0.333 \mathrm{~N}$ ) of these salts with the blunt-nosed minnow with temperatures at $12.8^{\circ}, 17.8^{\circ}, 22.8^{\circ}, 27.8^{\circ}$, and $32.8^{\circ} \mathrm{C}$. Tables III to VI give the effect of rise of temperature on the resistance of the flsh to these salts. Table VII shows the ratio of increase in toxicity with ten degrees increase in temperature of each of the four salts to the blunt-nosed minnow when the actual survival time or the velocity of fatality of the fish is taken as a criterion. When $0.227 \mathrm{~N}$. Calcium chloride with a ratio of 9.67 for $12.8^{\circ}$ to $22.8^{\circ} \mathrm{C} ., 0.025 \mathrm{~N}$. magnesium chloride with a ratio of 9.56 and $0.05 \mathrm{~N}$. magnesium chloride with a ratio of 17.75 for $17.8^{\circ}$ to $27.8^{\circ} \mathrm{C}$, and $0.1 \mathrm{~N}$. magnesium chloride with a ratio of 93.6 for $12.8^{\circ}$ to $22.8^{\circ} \mathrm{C}$. all of which are much larger than the ratios of the same column, are dropped from the averages it is seen that the ratio of increase in toxicity of each salt increases from the lower to the higher temperatures.

c. The Effect of Temperature on the Toxicity of Ammonium Chloride to Fish.

Experiments were run to show the effect of temperature on the resistance of fish to ammonium chloride. The results of these experiments are shown in Tables IX to XIII. The velocity of fatality was increased with rise in temperature with the same relative ratio as was the velocity of fatality of the goldfish with lithium chloride. The results of these experiments will be further discusser in connection with the van't Hoff rule and determination of the relative threshold of toxicity concentrations 

of deleterious substances.

d. The Relation of the Effect of Temperature on the Toxicity of Salts to Fish and van't Hoff's Rule.

Work that has been done on the influence of temperature on the reaction vejocity of metabolic processes (Hill, Moore, yacleod, Pembrey, and Beddard 1908) has shown two distinct effects, one upon the central nervous system causing variations in the functional activity of the organs, these in turn influence the metabolic processes andithe other on the tissucs themselves influencing the rate of metabolic processes. In warm bloode? animals low temperature stimulates the nerves which results in an increased metabolism and a rise in temperature results in a decrease in the rate of metabolisw. In cold blooded animals the action of the nerres themselves like the other organs of the animal is under the influence of temperature. Thus the metabolic processes are almost invariably increased with a rise of tempcrature and decreased with a lowering of temperature. An exception to this rule has been found however in the case of the honeyhee clusters in winter (Ph111ps and Denuth 1914). It has been round with cold blonded animals that the ratio of increase in rate of metaholism for each rise of ten degrecs centigrade as measured by oxygen consumption and carbon dioxide evolved and blological reactions in general approximates very closely two to three within certain temperature limits. This has been taken as proof that chemical dynamics hold within the animal organism. This view is held with greater confidence since it is known that the rule of $\operatorname{van}^{\prime} t$ Hoff is an empirical expression of the influence 

of temperature upon chemical processes. There is generally a slight decrease in the $Q_{10}$ of purely chemical processes with rise in temperature. Arrhenius formula $\frac{V_{1}}{V_{2}}=e^{\frac{7}{2} \frac{T_{1}-2}{T_{1} T_{2}}}$ has been taken as expressing more nearly the truth where $V_{1}$ is the velocity of the process at the absolute temperature $T_{1}$ and $q$ is the molecular heat of reaction. This formula has been very succossfully applied to a number of reactions of a chemico-nhysical nature, I.e., haemolytic actions of alkalies, acids, bacterial poisons, and snake venoms, the reakening at high temperatures of a number of antibodies, and the combination of haemoglobin with oxygen (cited by Krogh 1914c). The van't Hoff rule has been applied to many physiological processes, $1 . e .$, thrse processes which take place only in the living organism or organs. Most workers have considered temperatures of very narrow range and have used these results in calculating the $Q_{10}$ over a range of temperatures where this quotient does not hold. One has only to stop and think to see that the $Q_{10}$ will vary from a point where it approaches infinity on the one hand to a point where it drops to zero on the other hand at least in those animals which are able to be frozen or go into hibernation at very low temperatures. The $Q_{10}$ approaches just as near infinity when the hibernating animal passes out of the state of hibernation as the metabolic processes had approached zero during the hibernation of the animal. While on the other hand the $Q_{10}$ is reduced to zero when a temperm acure is reached at which all metabolic processes cease. Most workers have arbitrarily chosen the range of temperature that shows the $Q_{10}$ of the proper magnitude - between 2 and 3 - as 


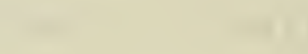


that which most reliance is to be placed. This generally approximates the mean of the temperature range for normal metabolic activity. 0thers seeing the variation of the $Q_{10}$ have attempted to explain its cause. Snyder (1911) has said, "in fact, the writer knows of no case where this variation does not occur". Blackman (1905) says, "as regards the rate of metabolic chemical change in the organism at high temperatures, this law clearly does not express the whole truth. If it did we should expect, with increasing temperature, all vital processes to proceed with ever-increasing velocity till the fatal temperature was reached at which some essential proteid coagulated or some other connexion was dislocated, and the whole metabolic machinery came surdenly to a standst111". The falling off of the $Q_{10}$ at higher temperatures is explained by Blackman as being due to a tine factor and he points out the fact that Sachs has shown that the higher the temperature the more quickly the fatal effect ensues and that a short exposure at high temperatures will not kill. while long exposures at lower temperatures will prove fatal. He concludes from Natthaei's 11904) experiments on carbon assimilatton that: 1. At high temperatures $\left(30^{\circ} \mathrm{C}\right.$. and above for cherryIaurels) the initial rate of assimilation cannot be maintained, but falls off regularly. 2. The higher the temperature the more rapid the rate of falling off. 3. The falling off at any given temperature is fastest at first and subsequently becomes less rapid. Blackman has calculated the theoretical initial value of assimilation Pron'the rate of falling off of the assimilation at any given temperature. Thus by extrapolation he has formulat- 

ed a curve at higher teinperatures which conforms to a van't Hoff curve. Pluter (1914) in his experiments on the skin respiration of the frog has attempted to show that the deviation of his curve from that of a van't Hoff curve was due to the superposition of exponentials. Snyder $(1908,1911)$ explains the variation as being due to the low difussion velocities, low temperature cocfricient of viscosity, the low temperature coefficients of dielectric capacities, and the migration velocities of lons. Osterhout (1917) suggests that when substances are formed and are at once broken down, as is the case with many metabolic processes the reactions which form the substances may differ from that which destroys it. This he claims would cause a variation in the $Q_{10}$. The direction or the variation would thus depend upon which of the two reactions had the larger coefficient:

It is not the purpose of this paper to produce evidence that any given physiological activity is or is not a chemical process rather than physical, but rather to detemine if there is any uniformity in biological reactions and if possible to determine in what way these processes are controlled by external factors. There secms to be a great uniformity in the trencl of the $Q_{10}$ wherever determinations have been made over any very great range of temperatures. In such diverse hiological reactions as the gastric hunger movements of certain of the lower animals (Patterson 1917), the regeneration and the duration of life of the Tubularia crocea (Moore 1910), the radial growth rate on solid medium of the fungus Pythiacystes atrophthora (Fawcett 1917), and many other biological reactions (Snyder 1908, 1911), the ran't Hoff coeficient - 2 to 3 - holds good for only a very 

narrow range of temperatures. When the literature on the cfrect of cnzyme action is examined the same thing is found to be true. Rahn (1916) who has collccted data on this point discusses this material in the light of Tramman's theory and subjects it to an exhaustive mathematical examination. Hc shows that in all cases that the temperature cocfficient is large at the lower temperatures and gradually decreases until at very high temperatures it drops to zero. Rahn suggests an explanation nf this variation of the temperature coefricient in that he bejieves that at least in such as the alcoholic fermentation that destruction of the enzyme (zymasc) occurs within the cell but at normal temperatures the enzyme is reproduced as rapidly as it is destroyed so that the amount of the enzyme remains the same. He also beleives that at higher temperatures Tamman's principle comes into play. He postulates a thermolabile agent in the cell and applies the same principle to growth and reproduction.

Green (1870), Earli (1878), Dannevig్g(1894), Edwards (1902), Reibisch (1902), Williamson (1010), Sanderson and Pealrs (1913), and Johansen and Krogh (1914) have done work leading up to the conception of thcrmal constant for biological reactions. Harrey (1911) showed that the rate of conduction of nerve impulse of the nerve-ring of the sub-umbrella of the medusa Cassinpea increased in a linear ratio as the temperature is raised. Mayer (1914) who repeated Harvey's experiments on Cassinpea xannchans affirmed Harvey's results, i.e., the increase in conduction of nerve impulses is arithmatically proportional to the incrcase in temperature. While finally Krogh $(1914,1914 a)$ and Sanderson 

and Peairs (1913) called attention to the close aproximation of thermal constants of development to an equilateral hyperbola when temperature is. plotted as abscissa and length of time required to pass any particular stage is plotted as ordinate. These workers hold that the effect of temperature on development does not follow $\operatorname{van}^{\prime} \mathrm{H}$ Hof's rule. Loeb and Northrop (1917) round the same high $Q_{10}$ for Drosophila larval and pupal stages at low temperatures with a gradual decrease up to the temperature at which development would no longer take place. But with the duration of IIfe of the imago stage their results were different. There was no tendency for the $Q_{10}$ to decrease at the higher temperatures but instead it increased. This fact was wed by Loeb and Yorthrop to strengthen tieir argumant that it was the falling off of the $Q_{10}$ in the larval and pupal stages that was responsiiie for the straight line limits of the velocity of development curve and states, "that the straight line cliaracter of the curve does not militate against the assumption that we are dealing in all these curves (curves for the rate of development of larvae and pupae and the duration of life of the imago and thc total duration of life of the (ruit-fly) with a temperature coefficient of the order of that of a chemical reaction". This secmingly unsimilarity of the two sets of curves will be discussed a little later. 



\section{A COMPARISON OF THE TEMPERATURE TOXICITY CURVE}

TO THE TEIPERATURE METABOIISM AND THE TEIPERATURL STANDARD METABOLISM CURVES OF OTHER WORKEMS

Krogh (1914c) in his work on the effect of temperature on what he calls standard metaboliem* has shown that $Q_{10}$ is not a constant but gradually decreases from the lower temperatures to the higher temperatures.

Leitch (1916) In attempting to show Blackman's method of extrapolation in calculating the effect of temperature on the growth rate of Pisum sativum untenable has compared his rate of growti curve to Krogh's standard metabolism curve and claims that the two are in agreement as well as a curve drawn from Kuijper's data on the effect of temperature on the respiration of Posum. Leitch claims that the $Q_{10}$ does not follow the van't Hoff rule. Others hare attempted to show the applicability of the van't Hoff rulc by approaching it from other points of view. As has already been mentioned Loeb and Northrop (1916) studied the effect of temperature on the duration of 1 ife of the fruit-fly. They determined both the duration of Iffe of the imago stage and the entire dur-

* Krogh defines standard metabolism as the metabolism obtained when no assimialtion of food is taking place, when morements are prevented, and muscular tone either abolished or brought down to a minimum. He states that when external conditions are unaltered that the metabolism is approximately constant at least over short periods of time. 

ation of 1ife. Lillie (1917) has studied the effect of temperature on the time required to activate starfish eggs by treatment with butyric acid. Groves (1917) determined the duration of the life of stored seed. These workers found no tendency for the $Q_{10}$ to decrease at the higher temperatures. Thus there is no portion of their reciprocal curves which approach a straight fine. This is additional proof that there is no portion of the reciprocal curres, i.e., the curves of the rate of development of any definite stage of the animal organism at different temperatures and of the velocity of fatality of fish in different concentrations of a toxic substance, which is actually a straight Iine but approaches a straight line where the curvature is changed from a concave upward direction to a concave downward direction due to the gradual decrease of the $Q_{10}$ with rise of temperature (Powcrs 1918). The extent of the region in which tilc reciprocal curves approach a straight line is dependent on the rapidity with which the $Q_{10}$ decreases in value with rise of temperature. When there is no decrease of the $Q_{10}$ as the temperature is raised or the decrease is not sufficiently ranid (Irogh, Q10 for metabolism of Tenebrio molitor $1914 \mathrm{~b}$ and the $\eta_{10}$ for standard metabolism 1914c) the reciprocal curve continues to be concare upwara. (In the metabolism reciprocal curves there is probably a rapid deerease in the $0_{10}$, $i . e .$, the upper temperature limits of metabols.sm, which will cause the reciprocal curve to change to a concave downiard direction. But at higher temperatures the metabolism becomes very irregular, Leitch 1916). When the survival time of the gold fish is taken as a criterion the efrect of temperature 
on the toxicity of the lithium chloride resembles that of the effect of temperature on standard metablism of goldfish as found by Krogh (1914c). Krogh found that the relative effect of temperaturc on standrad metabolism of a toad, a frog, a goldfish, and a puppy were approximately the same. Table II shows the Q10 for the toxicity of lithium chloride to goldfish when the actual survival time is taken as a criterion. This is not calculated but taken from actual experimental data of experiments which were run at approximately ten degree intervals. Table XIV shors the $Q_{10}$ when $K$ of the equation of the straight line of the theoretical velocity of fatality is taken as a measure of relative toxicity of the lithium chloride at different temperatures. The theoretical velocity of fatality curves of the goldfish when killed in lithium chloride solutions at $4^{\circ}, 11.8^{\circ}, 15.3^{\circ}, 20^{\circ}, 24.9^{\circ}$, $29.8^{\circ}$, and $34.8^{\circ} \mathrm{C}$. are shom in Figures 4 to 10 . These curves are irawn from data given in Table $I$. Figure 11 is the superimposition of the theoretical velocity of ratality curves for the temperatures tested. When the relative toxicities of the Iithium chloride at the different temperatures, Figure 11, is plotted a curve shown in Figure 12 is given. Figure 13 shows Krogh's temperature standard metabolism curve of certain vetebrates including a goldrish. Figure 14 is a graphic representation of the $Q_{10}$ when calculated on the basis of the temperature toxicity curve, Figure 12. See Table XIV. The more or less sharp upward trend of the $Q_{10}$ curve at the higher temperatures, Figure 14, is duc to an additional factor which has entered. That is, the higher temperatures is nearing the upper Iimits of temperature indurance of the goldfish. A few of the goldfish 

died in tap rater at $34.8 \mathrm{C}$. and all fish tested died when the tent perature was raised to 36 to $37 \mathrm{C}$.

When the temperature toxicity curve of the lithium chloride to golefish is compared to Krogh's temperature standard metabolism curve of vertcbrates, Figure 13, it is found that the two do not coincide but that the temperature toxicity curve approximates the square root of the temperature standard metabolism curve. (See curves, Figures 12 and 13). Table XV gives the ratio of the square root of Krogh's temperature standard metabolism curve and the temperature toxicity curre. This ratio shows a slight rise of the tcmperature toxicity curve above that of a square root of standara metabolism temperature curve both at the higher and lower temperatures. Loeb and Northrop's (1917) data (Table XVI) for the reciprocal of the total duration of Iife and the duration of life of the imago of the fruit-fly conforms fairly well with Krogh's (1914b) temperature metabolism curve for the pupa of Tenebrio molitor when relative values of the reciprocals of the dmration of life of the imago of the fruit-fiy are comnared to the metabolism of the pupae of the meal-worm at the same temperature. There is a slight variation at the higher temperatures. This is shown graphically in Figure 15. The curve was drawn from data taken from Krogh (19140). The plus signs ( $(t)$ represent the duration of life of the imago and the crosses (X) represent the total duration of life of the fruitfly. Lillie's data, on the other hand, for the activation of starfish eggs with butyric acid conforms less cxactly with Krogh's temperature metabolism curve. Table XVII, taken from Lillie (1917), gives the mein optimum time of exposure of star- 
fish egrs to $0.006 \mathrm{~N}$. butyric acid to activate them at different temperatures. Figure 16 shows the superimposition of the velocity actiration (the reciprocal of the time required to actiwate the starfish eggs with the butyric acid at different temperatures) of the starfish eggs,as calculated from Lillie's data, on Krogh's temperature metabolism curve. The crosses (X) represent group $A$ and the plus signs $(t)$ represent group $B$. This graph shows that the relocity of activation is higher at the lower and higher temperatures than the relative rate of metabolism of the pupa of the meal-irorm. Sollmann, Nendenhall, and Stingel (1915) found that the effect of temperature on the time required for systolic standstill or excised frog's heart injected with ouabain corresponded very nearly to the square of the heart rate quotient. These rorkers suggested as an explanation in the basis of Weizsaecker's observations that the activity of ouahin is proportion $\bar{a}$, independently, to two factors, viz., the heart rate and the temperature. That is, when the temperature and the activity of the heart both varied the activity of the ouabain rould increase by the temperature factor multiplied by the rate factor. And they suppose that the temperature affects the rate of the heart and the ouabain response about equally, and thus the temperature rould increase the activity by the square of the temperature quotient. The agreement of Loeb and Northrop's data to the temperature metabolism curve of Tenebrio molitor pupae is what one would expect provided that the relative effect of temperature on the metabolism of all invertebrates is the same. This last point has not been demonstrated. Howerer, Krogh has 

suggested its nossinility. Many insects in the imago stage do not take food. Thus you would expect at least that the duration of life in the imago stage to be very closely associated with the rate of motabolism. This point is rurther cmphasized by the fact that Krogh (1914a) found that the amount of carbon dioxide given off by the pupa of the meal-worm during the pupal stage is constant at all temperatures in which development was normal. Again the relation of time required to activate the starish egg with butyric acid (Ijliie 1917) at different temperatures and the temperature metabolism curre agrees with expectation. That is, according to hypothesis suggested by Lillie (1915, 1916) the activation process consists essentially in the production of a definite reaction product ảcsignated by Lillie as t?: activating substance. Lillie has shown that the rate at which the butyric acid takes part in the process of activation is dirccty proportional to its concentration and suggests that the interaction has the character of a monomolecular reaction. This being true the tomperature should effect the activating and the metabolic processes alike. Thus the relative increase in the amount of activating substance would be proportional to the relative increase in the rate of metabolism. By an inppection of the graph, Figure 16, it is seen that the relocity of activation is highor than the rate of metabolism of the pupa of the mealworm at both the low and high temperatures. This might be explained as Lillie has pointed out that tcmeratures below $8^{\circ} \mathrm{C}$. and aboee $28^{\circ} \mathrm{C}$. there is a marked activating effect on the eggs. This possibility will account for the higher rate of activation at these temperatunes. The fact that the effect of temperature 

on the toxicity of lithium chloride to the goldfish follows a curve which is the square root of the curve of the efrect of temperature on standard metabolism of the goldrish might be explained on the ground that the lithium chloride attacks some intermediary substance of metabolism. Burge, Neill, and Ashman (1918) have shown that chloroform, ether, magnesium sulphate, and certain other substances attack the catalase of the blond of the cat, dog, and rabbit when gircn thesc substances. Thus in this case one is dealing with the effect of a substance the ralue cf which is equal to the substance intreduced. While in the case of the actirating substance that is formed in the cgg of the starfish is determined by the rate at which the butyric acid acts on the reacting substance in the cell. Thus the efrect of the lithium chloride would have to be considered as a reacing substance and not as a product of a reaction. Thus from the lar of dynamo fes when the two reacting substances are effectcd at the same rate the effect on the reaction product would be couivalent to the square of the effect on the reacting substances in a dimolecular reaction or the effect on the rate or activity of the reacting substances would be the square root of the cfrect on the rate of production of the reaction product.

Experiments were also run witii the blunt-nosed minnow to determine, cf:nct of tmcperature on the toxic activily of ammonium chloride to this fish. The results of these experiments are shorn in $T a b l e s ~ I X, X$, ynd $x I$. Figures 17 , 18, and 19 are graphic reprosentations of these experiments. When the relatirc toxicities of the ammonium chloride at $14.2^{\circ}, 19.8^{\circ}$, and 
24. $0^{\circ} \mathrm{C}$. are superimposed on the tempertaure toxjcity curre of lithium chloride to the goldfish it is found that thicre is more or less agreement between these two sets of experiments. See Figure 20.

Although therc is a more or less of an agreement of the Krogh temperature standard metabolisn curve and the terperature toxicity curves of lithium chloride and ammonium chloride the explanation of the effect of temperature in increasing the activIty of a protoplasmic poison is no doubt not so simple. Other factors such as muscular activily, muscular tension, digestion, and other plysiological processes must be taken into consideration. This explanation has teen suggested only as a working hypothesis.

\section{A METHOD OF MEASURING RELATIVE RESISTANCES OF} FISH TO DELLTLIOUS SUBSTANCES AND THE CORPARATIVE RESISTANCE OF CERTAIN SPECIES OF FISH

In earlier work (Powers 1018), as has alreacy bccn stated, the relative toxicities of substances of certain posisons to goldfisk have been determined by the cxpression $\mathrm{T}=\sqrt{\frac{\tan \theta}{a}}$. In this work it has been frund more convenicnt to use the constant of the equation of the theoretical rejocity of fatality curve in detrmining the relative toxic activity of a substancc at difrerent temperatures. This cquation is the equation of a straight line since the tbooretical velocity of fatality is a straight line. The validity of this method can be shorn by a consideration of Figure 21. The curre CABG represents the relocity of fatality of the blunt-nosed minnow when killed in different con- 

centrations of ammonium chloride at $19.8^{\circ} \mathrm{C}$. when one block obscissa represents $0.008 N$. ammoniun chloride and the curve $\mathrm{C}^{\prime} \mathrm{A}^{\prime} \mathrm{B}^{\prime} \mathrm{G}^{\prime}$ represents the same data when one block crus ls $0.016 \mathrm{~N}$. anmonium chloride. In both clirves four blocks crdinate represents one unit of relocity of fatality. This is equivalent to haring two substances one of which has just twice the toxic activity as the otlier and in which bot? follow the same law. Thus any noint on the relocity of fatality curve $C^{\prime} A^{\prime} B^{\prime} G^{\prime}$ is just one half the distance from the Y-axis as the point on the velocity of fatality curve CABG on the same paraliel to the X-axis. Since this is true for any point on the velncity of fatality curre $C^{\top} A^{\prime} B^{\prime} C^{\prime}$ it is true for all points and is true for the portion $A^{\prime} B^{\prime}$ and $A B$ of the two curves. That is, the portions $A^{\prime} B^{\prime}$ and $A B$ or the curres bear the same relatbon to each other as the entire curves $C: A+B^{\prime} G^{\prime}$ and $C A B G$ bear to each otler. Thus what is true of the curres $C^{\prime} A^{\prime} \mathrm{B}^{\prime} \mathrm{G}^{\prime}$ ard $\mathrm{A} A \mathrm{BG}$ is also true of the curves $P^{\prime} \mathbb{A}^{\prime} \mathrm{B}^{\circ} \mathrm{F}^{\prime}$ and PABF. Thus the theoretical velocity of fatality curves can be taken as a representaljon of the true velocity of fatality curves. Since this is true the constant, $\mathbb{K}$, of the equation of the theorctical velocity of fatality curve is taken as the most natural criterion for the relative toxicity of any substance cr the rolative toxicities of the same substance at difoerent temperatures. The constant, $Y$, of the equation of the straight Iine can also be taken to represent the actual threshold of toxicity concentration $\mathrm{C}^{\prime}$ and $\mathrm{C}$ since they are parellel points on the two curves. It is also seen from the graphs that the true relative toxicilies cannot be determined by conparing the relative time requirca to 

kill the fish in the two substances but that ielalive loxicity can be determined more or less exactly by comparing the concentrations of the tro substances which kill the fish curing any fixed time. Figure 22 shows the same vclocity of fatality curve CABG as shown in Figure 21 and a hypothetical relocity of fatality curve $\mathrm{CA} \mathrm{P}^{\prime} \mathrm{F}{ }^{\prime}$ in which the cffect of the deletericus substance is increased by two due not to the toxic actirity of the substance but aue to the increased susceptihility of the fish to the toxic action of t?c substance as a result of the lighcr rate of metabnlism of the fish. That is, at any one concentration of tile delEtcrious substance the velocity of fatality of the fish with the higher rate of metabolism is twice as great as the one with the lower rate of metabolism. Thus, theorctically a fish of the same species would have the same threshold of toxicity concentratinn proviacd the difference of susceptibility was due only to the difference in the ratc of metabolism. This theoretical curve cloes not hold in its entirety at least for !'lanaria as Child (1915 and citations) has shown that at high concentraticns of certain toxic substances that the [lanaria with the highest rate of metablism die rirst vile at very low concentrations of the toxic substance the order of time until dcath is reversed, those with the lowest rate of metaholism dying first. otler factors such as size of the individual and the rate of absorption of the deleterious substance probably plays a part. This hypothetical curve call be taken only as illustrating the tendency of the direction of the velocity of ratality curve, when the velocity of fatality is cue to susceptibility of the fish and sliows that the equation of the straight line can be taken only as a close ap- 

proximation of relative toxic values and is more nearly the truth than any other criterion thus ral suggested as a measure of relative toxic activities. This hypothetical curve also explains why all theoretical velocity of fatality curves of toxic substances do not intersect at some one point on the Y-axis. That is, therc are tro factors to be taken into consideration in the detemination of relative toxicities. One is the difference in susceptibility of the fish to the toxic substances and the second is the difference in the toxic activities of the substances themsclves. There are certain evidences that the velocity of fatality curves of lithium chloride to goldfish at diffcrent temperatutes do not all mect at the same point, $S$, (Figures 4 to 10 and Figure 11) but this ras taken as an approximation of the truth and as a method which can be htilized in obtaining a better understanding of the relation of fish to deleterious substances.

When the equation of the straiglt line is used as a criterion for the measurement of the susceptibility of a fish to anmonium chloride the resistance of the fish which is the reciprncal of the susceptibility is found to be as follows:-

Notrópis blennius Gir. $\quad(1.5$ to $2.0 \mathrm{~g}$.$) has a resistance of 1.0$ Pimephales notatus Paf. (Approximately $2 \mathrm{~g})$.$" " " 1.5$ Carassius carassius L. (3.0 to $4.9 \mathrm{~g}$.$) " " " 3.0$ These calculations are marie for the size of the fish monm tioned above only. The order of the species maj not be the same at differcnt stages of the life history of the rish. 

A CONPARISON OF TIE REIATIVF TOXICITIES OF CERTAIN OF THE ENVIRONMETAL SALTS ANE THEIR EIECTRICAL CONDUCTANCE

Much work has been done to determine the exact cause of the toxicity of the elenents or the mechanism of their actions. Some of the earlier viers held were that the toxicity of the elements of isomerous groups werc associated with the atomic weights of the clements (Blake 1883, 1887) or their toxicity was associatec with their positirn in the periodic system (Botkin 1885). In resent years the toxicily of the elements have been attributed to the free electric charge or the atom itself while in the atomic state or that toxicity is due to the solubility of the substance. Nathews (1904) has suggcster solution tension of the element as a function of its physiological activity. When experiments rere run with the chlorides of sodium, magnesiun, calcium, and barium to determine the effect of the temperature on the toxicity of these salts the electrical conductance of each of the salts was cletermined at each of the temperatures to ascertain the relation of the toxicity and the electrical conductance of the salts if there be any.

When the relative toxicities of sodium chloride, Calcium chloride, magnesium chloride, and bariuw chloridc are approximated at $17.8^{\circ} \mathrm{C}$. by using the theoretical velocity or fatality as a criterion for the measurement of relative toxicity it is found that they arrange themselves in the order named with the least toxic first and the most toxic last. This can only be an approximation since there were only a few experiments made in the 

straight line limits of the velncity of fatality curve which seems to anproximate 0.25 . N. at least for the first three chlorIdes named. But when the velocities of fatalities of each of the concentrations at the different tcmperatures tested are averaged for each salt and the averages taken as a criterion for relative toxicity the arrangements of the salts in order of their relative toxicities is somewhat different. They arrange themselves as follows: - Hagnesium chloride, calcium chloride, sodium chloride, and barium chloride with the least toxic first and the most toxic last. This is due to the higl velocjties of ratality of the fish in sodium chloride at $22.8^{\circ}$ and $27.8^{\circ} \mathrm{C}$. Thesc two sets of experiments seem to be erratic as compared to other tomperatures at which the sodium chloridc was tested and also when the straight line critcrion is applied to the data at these high tomperatures. See Table III and compare to Tables IV, V, and VI. Horever neither of these orders given for the relative toxicities of the salts corresponds to the crder of electric conductance of the solutions of the salts tested. Compare Tables ITI, IV, V, and VI with Table VIII.

ANTAGONISN AND ITS POSSIBLE UTILITY IN NATURAL POLLUTED VIATE!S

A few experinents were run with calcium chloride and sodium cllloride to ascertain if there are any relations betwcen the antagonism curve and the toxicity curves of lhese two salts. A $0.297 \mathrm{~N}$. calcium chloride solution to which varying amounts of sodium chloride were added was tested. In these experimcnts, 

Table XVIII, that the antagonism of the sodium did not at any concentration tested amount to more than the additive cffect of the sodium chloride added. That is, from the pure calcium chlor Ide solution there is more or less of a decrease in the survival time of the fish. But by comparing Table xili with experiments in which the fish were killed at $22.8^{\circ} \mathrm{C}$, Table $\mathrm{V}$, it will be seen that the actual antagonistic efeect of the sodium chloride was increased up to the highost concentration of the sodium chloride used. That is, the falling off of the surviral time of the fish was less rapid in the mixture of the calcium chloride ${ }_{n}$ actual concentration of salts than an equivalcnt concentration of pure calcium chloride or sodium chloride, Table III. This actual antagonism continued to increase up to the highest concentration of the sodium chloride used,

In the experiments with a $0.297 \mathrm{~N}$. soditun chloride solutinn to which varying amounts of calcium chloride was added there was a greater antagonistic cffect than the additive effect of the calctum chloride added. The antagonistic effect increased over that of the additire effect of the calcium chloride added until the calcium chloride added amounted to approximately $10 \%$ of the total salts in solution. From this point on the surviral time of the fish fell continuously up to the lighest concentrations of the calcium chloride used, Table XIX.

These experinents show that therc is no relation between the antagonism and the toxicity curves. They also show that the antagonistic cffect of calcium chloride and sodium chloride is most erfective when the calciun chloride and the sodium chloride 

are present in the ratio of normal:ties of about one to ten. These results agree fairly well with those of osterhout (1014) who found the most effective ratio of equal toxic solutions of these two chlorides to be one of calcium cliloride to trenty of sodiur chloride. These experiments show in addition to the fact that a definite ratio must cxist between twn antagonizing salts to be most cffective that if this ratio is not approximated the addition of an antagonistic salt to a toxic solution may be detrimental instead of beneficial. Thus in all treatmonts of natural waters which have become polluted the ratin for the most antagonictic effect of the substance added must be determined for the treatment to be most effective.

\section{GENERAL DISCUSSTON}

The fact is well known that bodies of water become uninhabitable for some of the most valuable food fish both through natural causes and contamination. Work has been donc that indicate that the conditions (Shelford 1911, 1911a) and the reactions of the water (Shelford $1911 \mathrm{~b}$ and We11\$1915, 1.915a) have more to do in aetermining the habitability of a body of water tlan other factors such as the availability of food. Shelford (1911a) has shown thit fish do not always occur where its natural food is most abundant. It has been shown hy reaction experiments (Shelford and Allee 1913 and Wells 1915, 1915a) that the fish generally aroid injurious substances which they naturally encounter in nature. But (Shelford 1917) the avoidance of injurious substances which do not generally occur under natural conditinns is not so marked. In fact the rish may react positively to such 


$$
\text { . }
$$


substances.

Liebig's law of minimum, as is generally stated, "the yield of any crop always depends on the nutritire constituent which is present in minimum amount" (Hooker 1917), can be applied to the habitability of a body of water for fish. But as Livingston (1917) has stated, "this principle is still. quite incomplete logically and its statement will assuridly become more complex as our seience adrances". Hooker (1917) has called attention to the fact that Blackman has shown that the assimilation of carbon is rery complex and depends on at least six factors; 1. Temperature, 2. Light intensity, 3. Carbon dioxide supply, 4. Vater supply, 5. Chlorophyl1, and 6. Enzymes. With fish the deleterinus effect of a substance may depend on the stage of the life history of the fish, whether it be the developing egg, a young and rapidly growing fry, or an older or an adult fish. And while in any of the free moving stages of the life history of the fish the effect of the deleterious substance might be determined by the physiolngical state of the fish which will cause it to become morc sensitive or less sensitive and thus react more energetically or less energetically to any environmental factor. While at all stages of the life history of the fish a deleterious substance may become injurious more rapidly under one set of conditions than under another set of conditions. Or a substance may not be injurious under one set of conditions while under other conditions it would be injurious. One of the environmental factors which determine the rapidity with which a substance becomes fatal is temperature. Temperature has been shown by the chemist and 

physicist to Increasc the rate of chemical and physical phenomena up to the point where the substances are brosken down or destroyed at the giren temperature. The same is true of biological reactions witl certain qualifications, 1.e., at higher tcmperatures these reactions become irregular and in fact are retarded in rate.

The purpose of the experincnts discussed in the preceeding pages was to show the relation of the temperature factor on the effect of deleterious substances on the fish in natural bodics of water. The question is raised is the effect of deleterious substances on the fish due only to the physiological state of the fish or are there other factors to be taken into consideration. And if there is a change in the physiological state of the fish is this change of such a nature that it makes the fish more resistant when the deleterirus substance is most active or does the resistance of the fish fall with the rise in the actirity of the injurious substance or substances. Wells (1916) has drawn a curve from data of experiments to show the seasonal resistance of the rock bass (Ambloplites rupestris Paf.) to lack of oxygen. His curve shows that the rock bass is least resistant to lack of oxygen in nugust. Its resistance rises very slowly during Septcmber and octeber and reaches its maximum during $\Lambda$ pril and May after which it falls rapialy to its lowest ebb at the last of JuIy and in August. No temperature data is given. So it is not known just what part temperature played in these experiments. Experiments al ready discussed slow that there is a marked fall of resistance of a fish to a deleterinus substance with rise In temperature. Thus the resistance of a fish as efrected by 
.

.

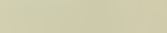

-

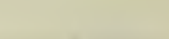

$+2$

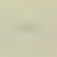

$+$ 
temperature is lesst during the sumer months and rises during the fall reaching 1 ts highest point during the winter months and falling again during the spring. Not only would there be a seasonal rhythm but there would be a daily rhythm. Thus the liabitability of bodies of water would depend on the length of the warn season. The longer the duration of the warm season the more fatal would be the effect. Or if there is a difference in the resistance of the different stages of the life history of the fish or the physiological state of the fish due to seasonal rhythm the habitability of the body of water would then depend on the temperature of the water at the period that the fish is least resistant, or the stage at which it is most sensitive and reacts most vigorously to invironmental or pullution factors.

In resent years the fish culturist has become intercsted in making bodies of water which have been made uninhabitable by pollution again favorable for fish habitation. This is not only a question of making the polluted waters habitable but the questinn arises as to the effect of other environmental factors. A substance which is not present in amount. sufficicntly great to be fatal to the fish might be made to become so erch by the addition of an antagonistjc substance or substances provided that the pronortions of the suhstances do not approximate a certain definite ratio. Experiments have been performed which show that calcium chloride $(0.297 \mathrm{~N}$.$) is made more rapidly fatal by the addition$ of small amounts of sodum chloride although the amount of sodium chloride added alone would not be fatal. With $0.297 \mathrm{~N}$. sodium chloride the addition of calcium chloride in small amounts decreasthe rapidity of fatality of the sodium chloride until a certain 
maximum effect is reached, i.e., when the proportion of the tro salts is approximately $10 \%$ calcium chloride and $90 \%$ sodium chloride. This agrees fairly rell with Osterhout's (1914) results on the antagonistic effect of these two salts on the grwoth in plants. This is especially imortant in the proposed treatment of polluted streams. In othercrords if the correct proportion of antagonizing substance is not added the effect might be detrimental rather than beneficial.

All these facts have important bearing on the prowlem dealing with the rish in relation to its environment. It is hoped that not only similar work will be undertaken not only with the different stages of the life history of the fish and that the most sensitive stage will be determiner.

\section{SUMAARY OF CONCIUSIONS}

1. The toxicities of the chlorides of lithium, a'monium, sodium, calcium, magnesium, and barium to fish are increased with rise of temperature.

2. The effect of temperature on the toxicities of the chlorides of lithium and ammonium do not follow van't Hoff's rule in its entirety.

3. The relatire toxicities of lithium chloride at differcnt temperatures to the golarish follow very closely the square root of relative standard metabolism of the goldfish as given by Krogh.

4. A close approximation of the relative deleterious effect of obnoxious substances to fish can be determined by comparing the constants of the equations of the theoretical velocity of fatality curres of the fish when killed in these substances. 

ance of the fish to these deleterious substances can be determined by the same method since the resistance of the fish is the reciprom cal of the deleterious effect of the substance on the fish.

5. The relative toxicities of sodium chloride, magnesium chlnxide, calciun chloride, and barium chloride to the blunt-nosed minnow (Pimcphales notatus Raf.) arc not the same as the relatire conductance of these salts.

6. The relative resistance of Carassius carassius L., Pimenhales notatus Rar., and Retropis blennius Gir., to ammonium chloride decreases in the order mamed.

\section{ACIKNOWLDGEMENS.}

The author wishes to thank Professor Jakoh Kunz and Doctor J. G. Dietrichson for assistance and many kelpful sugerestions in the determination of the conductance of the salt solutinns. The author also wishes to thank Professors C. T. Tininn and J. M. Snodgrass and Mr. C. F. Miller for the loan of apparatus. 



\section{BIBLIOGR:PHY}

Apstein, C.

1911. Die Verbreitung der pelagischen Fischeier und Tarven in der Beltsee und den angrenzenden Meeresteilen. Wiss. ircersunters., N. F., Keil, 13:225-281.

Bacrort, J. and Hill, A. V.

1910. The Nature of Oxyhaemoglobin, with a note on its Molccular Weight. Jour. Physiol., 39:411-428.

Blackman, F. F.

1905. Cptima and Limiting Factors. Ann. Bot., 19:281-205. Blake, J .

1883. On the Connection Between Physiological Action and Chemical Constitution. Jour. Physiol., 5:35-44.

1887. Relation of the Chemical Consilution of Inorganic Compounds to their Physiological Action. Chem. News, $55: 110-111$

Burge, W. E.

1917. The Effect of Ether Anaesthesia, the Emotions and Stimulation of the Splanchnics on the Catalase content of tlie Blood. Amer. Jour. Physio1., 41:290-297.

1917a. Why Chloroform is a More Powerful and Dangcrous Inesthetic than Ether. Science, n.s., 46:618-620. Burge, W. E., Neill, A. J., and Ashman, R.

1918. The Mechanism of the Action of Anacsthetics. Amer. Jour. Physiol., 45:388-395.

1918a. The Mode of $\Lambda$ ction of Food in Increasing Cxidation. Amer. Jour. Physio1., 45:500-506. 

Child, C. M.

1913. Studies on the Dynamics of Morphogenesis and Inheritancein Dannerig, H.

Experimental Reproduction. Jour. Fxp.Znol., 11:155-2nG.

1891. The Influence of Temperature on the Development of the Eggs of Fishes. 13th Ann. Rept. of the Fisheries Board for Scotland, pp. 147-153.

Earll, R. E.

1878. A Report on the History and Present Conditions of the Shore Cod Fisheries. U. S. Fish. Com. Rept., Pt. IV: $685-731$.

Edwards, C. L.

1902. The Physiological Zero and the Index of Development for the Egg of the Domestic Fowl, Gallus domesticus. Amer. Jour. Physiol., 6:351-397.

Faycett, H. S.

1917. Preliminary Note on the Relation of Temperature to the Growth of Certain Parasitic Fungi in Cultures. Inhns Hopkins Univ. Cir., 293:193-191.

Green, S .

1870. Trout Culture, Rochester.

Groves, J. F.

1917. Temperature and Life duration of Seeds. Bot. Gaz., $63: 169-189$

Harvey, E. N.

1911. The Effect of Different Temperatures on the Medusa Cassiopea, with special reference to the Rate of Conduction of the Nerve Impulse. Papers Tortugas Lab. Carnegie Inst. Washington, no. 132, 3:29-39

Hewitt, F. W.

1907. Inaesthetics and their Administration, New York. 

Hill, L., Noore, B., MacLeod, J.J. R., Pembrey, M. S., and Beddard, A. P.

1908. Recent Advances in Physiology and Bio-Chemistry, London. Hooker, II. D.

1917. Isiehig's Law of the Minimum in relation to General Biological Problems. Science, n.s., 46:197-204,

Johansen, $\Lambda . C$. and Krogh, A.

1914. The Influence of Temperature and Certain other Factors on the Rate of Development of Fishes. Conseil Tnternat. p. I'cxpl. de la mer. Pub. de Circunstance, no. 68.

Krogh, A.

1914. On the Influence of the Temperature on the Rate of Fmbryonic Development. Zeit. allgem. Physiol., 16:163177.

1914a. On the Rate of Development and $\mathrm{CO}_{2}$ Production of Chrysalides of Tenebrio molitor at different Temperatures. Zeit. allgem. Physiol., 16:178-190.

1914b. Ein Mikrorespiralionsapparat und einige damit auşefuhrte Versuche Uber die Temperatur-sionfwechsclkurve von Insektenpuppen. Biochem. Zeit., 62:266-279.

1914c. The quantitative Relation between Temperature and Standard Netabolism in Animals. Internat. Zeit. Plys.chem. Biol, 1:191-508.

Laurens, II.

1914. The Influence of 'lemperature on the Rate nf the lleart Bcet in Amb1yotoma Embryos. Amer. Jour. Pliysicl., 25: $199-210$. 

Leitch, I.

1916. Some Experiments on the Influence of Temperature on the Rate of Growth in Pisum sativun. Ann. Bot., 30: $25-46$

Lillie, R. S.

1915. On the Conditions of Activation of Unfertilized Starfish Eggs under the Influence of High Temperatures and Fatty Acid Solutions. Biol. Bull., 28:260-303.

1916. Mass Action in the Activation of Unfertilized Starfish Eggs by Butyric Acid. Jour. Biol. Chem., 24:233-247.

1917. Temperature-Coefficients in the Activation of starfish Eggs by Butyric Acid. Biol. Bull,, 32:131-158.

Livingston, B. E.

1917. A Quarter Century of Growth in Plant Physiology. Plant Vorld, 20:1-15.

Loeb, J. and Ewald, H. F.

1913. Die Frequenz der Herzthtigkeit als eindeutige Funktion der Temperatur. Biochem. Ze1t., 58:177-185.

Loeb, J. and Northrop, J.H.

1917. On the Influence of Food and Temperature upon the Duration of Life. Jour. Biol. Chem., 32:103-126.

Mathews, A. P.

1904. The Relation between Solution Tension, Atomic Volume, and the Physiological Action of the rlements. Amer. Jour. Physiol., 10:290-323.

Nat thaei, G. I. C.

1904. Fxperimental Researches on Vegetable Assimilation and 

Respiration. III. On the effect of Temperature on Carbon-ninxide Assimilation. Phil. Trans. Noy. Soc. London, 197B:47-105.

Mayer, A. G.

1914. The Effects of Temperature upon Tropical Marine AnimaIs. Papers Tortugas Lab. Carnegie Inst. Washington, no. 183, $6: 1-24$

Moore, A. R.

1910. The Temperature Coefficient for the Process of Regenerm ation in Tubularia crocea. Arch. Entwickl. Organ., $29: 146-149$.

Osterhout, $\mathbb{H}^{r}, \mathrm{~J} . \mathrm{V}$.

1914. Quantitatire Criteria of Antagonism. Bot. Gaz., 58:178186.

1917. Some Aspects of the Temperature Coefficient of Iife Processes. Jour. B101. Chem., 32:23-27.

Patterson, T. L.

1917. The Influence of Temperature on the Gastric Hunger Contractions of some of the Lower Animals. Amer. Jour. Physiol., 42:602.

Philitps, E. F. and Detmuth, G. S.

1914. The Temperature of the Honeybee cluster in finter. Bull. U. S. Dept. Agr., no. 93:1-16.

Powers, E. B.

1918. The Goldrish (Carassius carassius L.) as a Test Animal in the study of Toxicity. Tll. Biol. Mon., vol. TV, no. 2 . 

Pthter, A.

1914. Temperaturkoefizienten. Zeit. allgem. Physiol., 16: $574-627$.

Rahn, 0 .

1916. Der Einfluss der Temperatur und der Gifte auf Enzymwirkung, Grung und Wachstum. Blochem. Zeit., 72:351377.

Reibisch, J.

1902. Ueber den Einfluss der Tomperatur auf die Entwicklung von Fisch-Fiern. Wiss. Meersunters., N. F., Kiel, 6: $215-231$.

Sanderson, E. D. and Peairs, L. M.

1913. The Relation of Temperature to Insect Life. Tech. Bull. N. H. Co11. Agr. Exp. Sta., 7:1-125.

Shelford, V. E.

1911. Fcological Succession. It Stream Fishes and the Nethod of Physiographic Analysis. Biol. Bull., 21:?-35.

1911a. Ecological Succession. II. Pond Fishes. Biol. Bull., $21: 127-151$

1911b. Ecological Succession. III. 1 Peconnaissance of its Causes in Ponds with Particular Reference to Fish. Biol. Bul1., 22:1-38.

Shelford, V. E. and $\Lambda 1$ lee, W. C.

1913. The Reactions of Fishes to Gradients of Dissolred Atmospheric Gases. Jour. Exp. Zool., 14:207-266. 

Sollmann, T., Nendenhall, H. L., and Stingel, J. L.

1915. The Influence of Temperature and Concentratins cn the Ruantilative Reactinn of the Heart to Ouabain. Jour. Pharm. Fxp. Ther., 6:533-560.

Snyder, C, n.

1008. A Comparative Stucy of the Temperature Cocfoicicnts of the Velocities of Various Physiological Actions. Amer. Jour. Physiol. 22: 309-334.

1911. On the Neaning of Variation in the Nagnitude of Temperature coefficients of Physiolngical Processes. Mmer. Jour. Physiol, 28:167-175.

Warien, $\Gamma$.

1900. On the Reaction of Japlinia magna (Straus) to cortain Changes in its Farironment. Cuart. Jour. Micr. Sci., $13: 130-224$.

I.el1s, M. M.

1913. The Pesistance of Fishes to Different Concentratinns and Combinations of nxygen and Carbon Dioxide. Biol. Buil., 25:223-347.

1915. Reactions and Resistance of Fishes in Their Nalural Enviromment to Acidity, Alkalinity and Neutrality. Biol. Bull., 20:221-257.

1915a. The Reacticns and Resistance or Fishes in Their Natural Enviroment to Salts. Jour. Exp. Zool., 1?:213-283. 1916. Starvation and Resistance or Fishes to Tack of Oxygen and to KCN. Biol. Bul1., 31:441-452. 

Williamson, C.

1910. Experiments to show the Influence of Cold in Retarding the Development of Eggs of the Herroing (clupea hagengus L.), Plaice (Pleuronectes platessa...) and Haddock (Gadus oeglefinus '.). Fisheries Board of scotland, 27 th Rept. for 1908.

Woodruff, L. L. and Baitsel1, G. A.

1911. The Temperature Coefficient of the Rate of neproduction of Paramaccium aureiia. Amer. Jour. Physiol., 2n:147155. 

TABLE T .

The survival time and the velocity of fatality of goldfish in lithium: chloride. Column 5 gives relative conductance.

\begin{tabular}{|c|c|c|c|c|}
\hline $\begin{array}{l}\text { Normal } \\
\text { LICl }\end{array}$ & $\begin{array}{l}\text { Weight } \\
\text { of fish }\end{array}$ & $\begin{array}{c}\text { Survival } \\
\text { time of }\end{array}$ & $\begin{array}{c}\text { Velocity of } \\
\text { fatality }\end{array}$ & $\begin{array}{l}\text { Relative } \\
\text { conductance }\end{array}$ \\
\hline $4^{\circ} \mathrm{C}$ & $\begin{array}{l}\text { In } \\
\text { grams }\end{array}$ & $\begin{array}{l}\text { fish in } \\
\text { minutes }\end{array}$ & $100 / t$ & \\
\hline 0.058 & $\begin{array}{l}1.6 \\
2.0\end{array}$ & $\begin{array}{l}1411 \\
1260\end{array}$ & $\begin{array}{l}0.07 \\
0.08\end{array}$ & 1.27 \\
\hline 0.116 & 1.5 & 685 & $0: 46$ & 2.43 \\
\hline " & 1.6 & 685 & 0.146 & 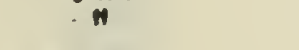 \\
\hline 0.232 & 1.0 & 112 & 0.89 & 4.61 \\
\hline n & 1.7 & 125 & 0.80 & 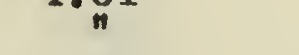 \\
\hline 0.302 & 1.2 & 106 & 0.94 & 5.79 \\
\hline & 2.2 & 112 & 0.90 & \\
\hline 0.372 & 1.2 & 72 & 1.37 & 7.04 \\
\hline & 1.2 & 72 & 1.37 & \\
\hline 0.488 & $1: 2$ & 48 & 2.08 & 8.84 \\
\hline
\end{tabular}

$11.8^{\circ} \mathrm{C}$.

\begin{tabular}{|c|c|c|c|c|}
\hline 0.058 & $1: 8$ & 526 & 0.19 & 1.67 \\
\hline & 1.8 & 800 & 0.12 & \\
\hline 0.116 & 2.8 & 359 & 0.28 & 3.15 \\
\hline & 2.8 & 369 & 0.27 & \\
\hline 0.232 & 1.7 & 131 & 0.76 & 6.00 \\
\hline & 1.7 & 131 & 0.76 & \\
\hline 0.302 & 1.2 & 82 & 1.22 & 7.60 \\
\hline " & 1.9 & 74 & $1: 35$ & \\
\hline 0.372 & $1: 9$ & 64 & $1: 59$ & 9.36 \\
\hline & 2.1 & 69 & 1.45 & \\
\hline 0.488 & 1.6 & 42 & 2.38 & 11.66 \\
\hline & 19 & 15 & & \\
\hline
\end{tabular}

$15.3^{\circ} \mathrm{C}$.

$\begin{array}{ccccc}0.058 & 1.5 & 524 & 0.19 & 1.88 \\ 0.116 & 1.5 & 702 & 0.14 & n \\ 0.7 & 1.7 & 457 & 0.22 & 3.53 \\ 0.232 & 2.3 & 413 & 0.24 & n \\ n & 1.2 & 61 & 1.64 & 6.64 \\ 0.302 & 2.2 & 87 & 1.15 & \\ n n & 1.0 & 58 & 1.72 & 8.42 \\ 0.372 & 1.0 & 58 & 1.72 & n \\ n & 1.1 & 49 & 2.41 & 10.37 \\ & 1.2 & 34 & 2.94 & \end{array}$



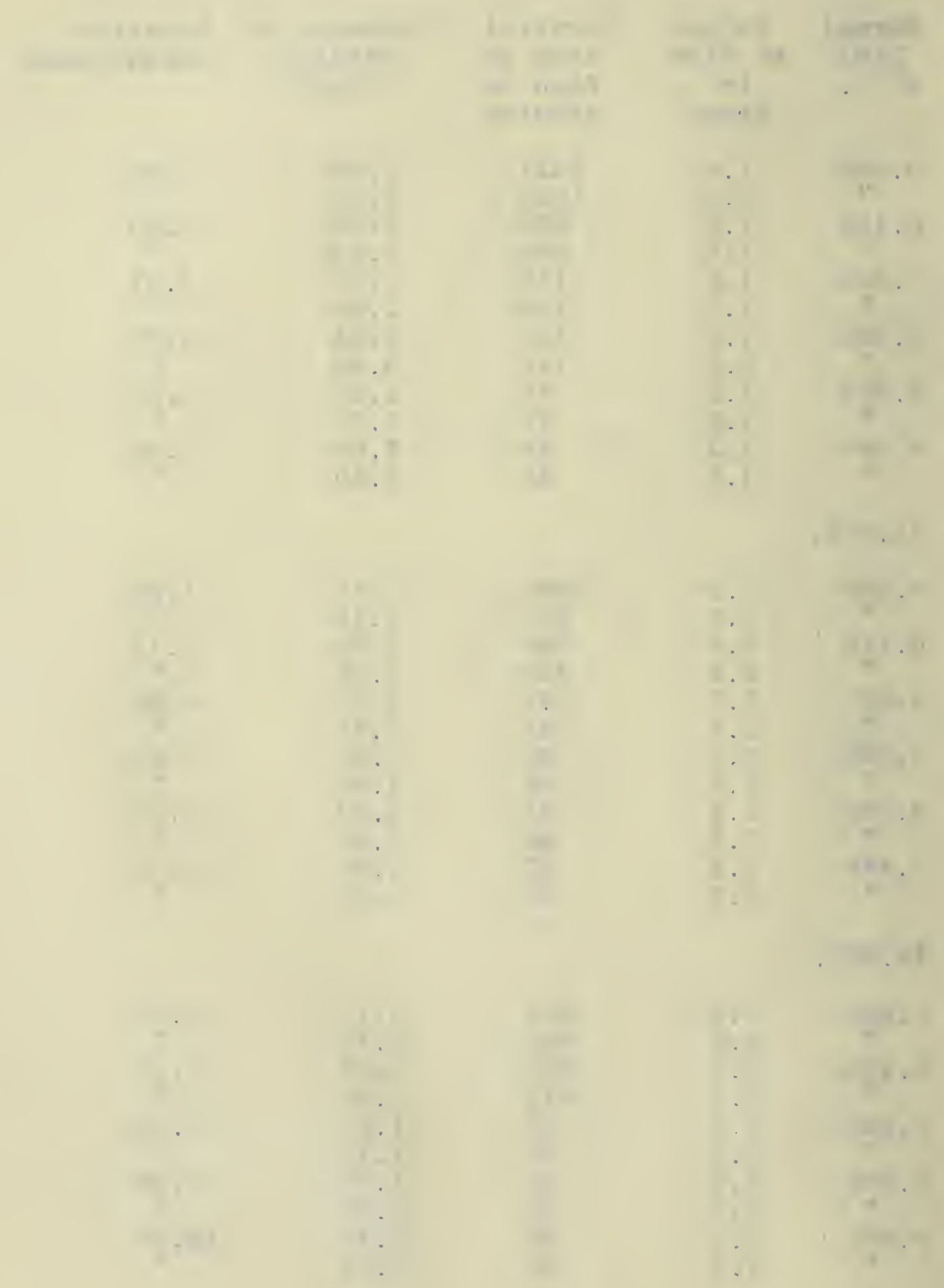
TABLE I Continued.

Normal Weight Survival Velocity of Relative

$\begin{array}{cccc}\text { LiCl of fish time of catality conductance } \\ 20^{\circ} \mathrm{C} . & \text { in } & \text { fish in } & \end{array}$ grams minutes

\begin{tabular}{|c|c|c|c|c|}
\hline 0.046 & $1: 0$ & 544 & $0: 18$ & 1.68 \\
\hline 0.058 & $\begin{array}{l}1: 4 \\
1.5\end{array}$ & $\begin{array}{l}410 \\
803\end{array}$ & $\begin{array}{l}0.24 \\
0.12\end{array}$ & 2. 20 \\
\hline 0.093 & $\begin{array}{l}1.1 \\
2: 7\end{array}$ & $\begin{array}{l}152 \\
213\end{array}$ & $\begin{array}{l}0.66 \\
0.47\end{array}$ & 3.18 \\
\hline 0.116 & 1.3 & $\begin{array}{l}192 \\
255\end{array}$ & $\begin{array}{l}0: 52 \\
0: 39\end{array}$ & 3. 99 \\
\hline 0.151 & $\begin{array}{l}1: 2 \\
1: 2\end{array}$ & $\begin{array}{l}75 \\
80\end{array}$ & $\begin{array}{l}1: 34 \\
1: 25\end{array}$ & 5.09 \\
\hline 0.232 & $\begin{array}{l}0.9 \\
1.4\end{array}$ & $\begin{array}{l}57 \\
81\end{array}$ & $\begin{array}{l}1.76 \\
1.23\end{array}$ & 7.44 \\
\hline 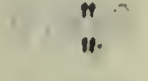 & $\begin{array}{l}1.0 \\
1.0\end{array}$ & $\begin{array}{l}35 \\
36\end{array}$ & $\begin{array}{l}2.86 \\
2.78\end{array}$ & 7.45 \\
\hline 0.267 & $\begin{array}{l}1: 4 \\
1: 4\end{array}$ & $\begin{array}{l}34 \\
35\end{array}$ & $\begin{array}{l}2.94 \\
2.86\end{array}$ & 8.45 \\
\hline 0.302 & $\begin{array}{l}1.2 \\
1.4\end{array}$ & $\begin{array}{l}46 \\
46\end{array}$ & $\begin{array}{l}2.17 \\
2.17\end{array}$ & 9.44 \\
\hline 0.418 & $\begin{array}{l}1: 2 \\
1: 4\end{array}$ & $\begin{array}{l}30 \\
31\end{array}$ & $\begin{array}{l}3.33 \\
3.52\end{array}$ & 12.53 \\
\hline $\begin{array}{l}0.488 \\
? .4\end{array}$ & $\begin{array}{l}1 ; 6 \\
1.6\end{array}$ & $\begin{array}{l}35 \\
35\end{array}$ & $\begin{array}{l}2.81 \\
2.81\end{array}$ & 14.37 \\
\hline
\end{tabular}

$21.9^{\circ} \mathrm{C}$

$\begin{array}{ccccc}0.058 & 1.8 & 322 & 0.31 & 2.31 \\ 0.116 & 2.3 & 466 & 0.21 & \\ 0.232 & 1.3 & 152 & 0.66 & 4.43 \\ 0.302 & 1.3 & 157 & 0.64 & 8.40 \\ 0.372 & 1.3 & 237 & 2.73 & 10.54 \\ 0 & 1.5 & 38 & 2.62 & \\ 0 & 2.3 & 27 & 3.72 & 13.30 \\ & 2.1 & 36 & 2.79 & \end{array}$

$29.8^{\circ} \mathrm{C}$

\begin{tabular}{|c|c|c|c|c|}
\hline 0.046 & 0.9 & 224 & 0.45 & 2.09 \\
\hline 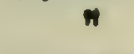 & 1.4 & 244 & 0.41 & \\
\hline 0.058 & $\begin{array}{l}1.3 \\
1.5\end{array}$ & $\begin{array}{l}224 \\
263\end{array}$ & $\begin{array}{l}0: 45 \\
0: 38\end{array}$ & 2.53 \\
\hline 0.093 & $\begin{array}{l}1: 1 \\
1.6\end{array}$ & $\begin{array}{l}98 \\
98\end{array}$ & $\begin{array}{l}1: 02 \\
1: 02\end{array}$ & 3.94 \\
\hline 0.116 & $\begin{array}{l}1.1 \\
1.6\end{array}$ & $\begin{array}{l}110 \\
124\end{array}$ & $\begin{array}{l}0.91 \\
0.81\end{array}$ & $4 \cdot 91$ \\
\hline 0.151 & $\begin{array}{l}1.1 \\
1.4\end{array}$ & $\begin{array}{l}44 \\
49\end{array}$ & $\begin{array}{l}2: 27 \\
2: 02\end{array}$ & $2 ?$ \\
\hline 0.232 & $\begin{array}{l}1: 1 \\
2.0\end{array}$ & $\begin{array}{l}25 \\
36\end{array}$ & $\begin{array}{l}4.00 \\
2.78\end{array}$ & .32 \\
\hline
\end{tabular}



TABLE I, Continued.

Normal Weight Surrival velocity of Relative

LiCl of fish time of

$29.8^{\circ} \mathrm{C}$ in $\mathrm{flsh}$ in fatality conductance grams minutes

\begin{tabular}{|c|c|c|c|c|}
\hline p, 267 & 1.2 & 19 & 5.26 & 10.30 \\
\hline 0.302 & $\begin{array}{l}1.4 \\
1.6\end{array}$ & $\begin{array}{l}16 \\
22\end{array}$ & $\begin{array}{l}6.25 \\
4.55\end{array}$ & 11.66 \\
\hline & 2.0 & 36 & 2.78 & \\
\hline 0.337 & 1.1 & 14 & 7.14 & 12.70 \\
\hline & 1.6 & 17 & 5.88 & \\
\hline 0.372 & 1.3 & 17 & 5.88 & 13.71 \\
\hline 0.488 & $\begin{array}{l}2.3 \\
1.3\end{array}$ & $\begin{array}{l}18 \\
10 .\end{array}$ & $\begin{array}{r}5.56 \\
10.00\end{array}$ & 17.70 \\
\hline $34.8^{\circ} \mathrm{C}$ & & & & \\
\hline 0.046 & 1.4 & 17 & 5.88 & \\
\hline & 1.7 & 50 & 2.00 & \\
\hline 0.058 & $\begin{array}{l}1.3 \\
1.3\end{array}$ & 32 & $\begin{array}{l}3.63 \\
2.42\end{array}$ & 2.79 \\
\hline 0.116 & 1.2 & 37 & 2.73 & 1 \\
\hline & 1.4 & 61 & 1.64 & \\
\hline 0.232 & 1.1 & 10 & 10.00 & 10.45 \\
\hline & 1.3 & 15 & 6.67 & \\
\hline 0.302 & 1.0 & 8 & 12.50 & 12.80 \\
\hline & 1.9 & 8 & 12.50 & \\
\hline 0.372 & 1.3 & 7 & 14.28 & 14.71 \\
\hline & 1.7 & 8 & 12.50 & \\
\hline
\end{tabular}



TABLE II.

The ratio of increase in toxicity of Ilthim chloride to the goldfish, Carassius carassius L., with an increase of 10 degrees centigrade, approximately.

Normal $4.0^{\circ}$ to $4.0^{\circ}$ to $11.8^{\circ}$ to $15.1^{\circ}$ to $20.0^{\circ}$ to $25.3^{\circ}$ to $11.8^{\circ} \mathrm{C} .15 .1^{\circ} \mathrm{C} .20 .0^{\circ} \mathrm{C} .25 .3^{\circ} \mathrm{C}, 29.8^{\circ} \mathrm{C}, 34.8^{\circ} \mathrm{C}$.

\begin{tabular}{|c|c|c|c|c|c|c|}
\hline 0.046 & ---- & --- & $m-m$ & $m$ & 2.32 & 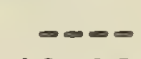 \\
\hline 0.058 & 1.97 & 2.15 & 1.09 & 1.56 & 3.53 & 10.08 \\
\hline 0.093 & --- & $\ldots$ & $\cdots$ & amanom & 1.87 & $-\cdots$ \\
\hline 0.116 & 1.73 & 1.58 & 1.60 & 2.85 & 1.91 & 3.15 \\
\hline 0.151 & $-\cdots$ & $\therefore-$ & $\cdots$ & $-\cdots-$ & 1.67 & \\
\hline 0.232 & 0.91 & 1.60 & 3.69 & 1.98 & 1.16 & 3.00 \\
\hline 0.267 & $\cdots$ & $\therefore-$ & $\cdots$ & $m-$ & 1.97 & -- \\
\hline 0.302 & 1.35 & 1.88 & 3.39 & 1.86 & 1.59 & 3.94 \\
\hline 0.337 & $-\cdots$ & $m$ & $\cdots$ & $\cdots-\infty$ & 1.97 & $=-\infty$ \\
\hline c.372 & 1.08 & 1.05 & $\cdots$ & 1.73 & $-\cdots$ & 3.20 \\
\hline 0.488 & 1.04 & $=--$ & 1.24 & $m-$ & 3.50 & --1 \\
\hline ges & & & $\overline{2.20}$ & 00 & Tा5 & 9.01 \\
\hline
\end{tabular}




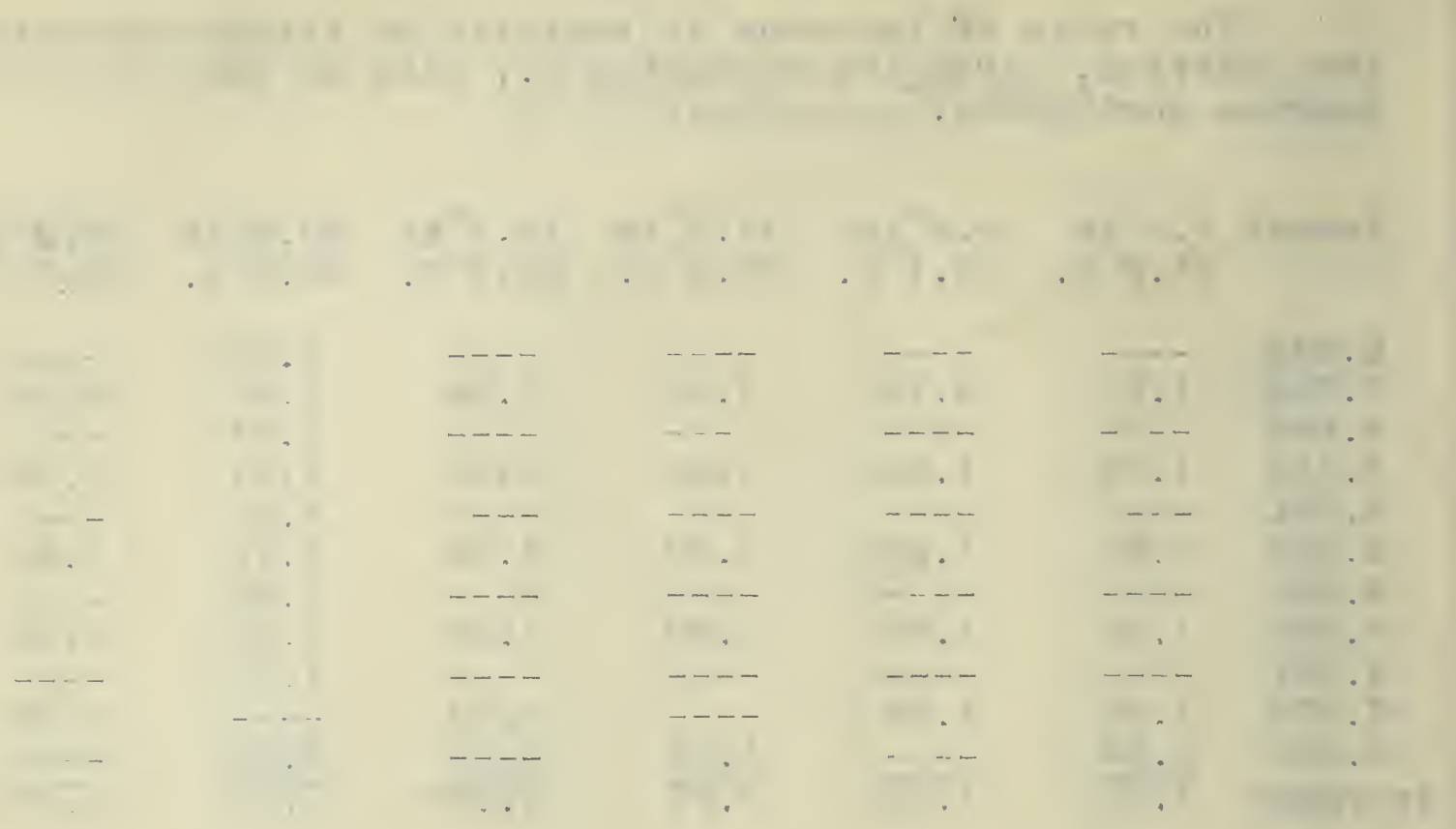


The surviral time and the velocity pf fatality of the blunt-rosed minnor, Plmephales notatus Raf,; chloride. Colum 5 gives relative conductance.

Normal Weight Surviral velocity of Relative $\begin{array}{cccc}\text { NaCl of fish time of fatality conductance } \\ 12.8^{\circ} \mathrm{C} \text {. In } & \text { fish in } & \end{array}$ $12.8^{\circ} \mathrm{C} . \underset{\text { grams }}{\text { In }}$ minutes

\begin{tabular}{|c|c|c|c|c|}
\hline 0.025 & $---*$ & $\begin{array}{l}21600 * \pm \\
21600 * \pm\end{array}$ & $\begin{array}{l}0.005 \\
0.005\end{array}$ & 1.0 \\
\hline 0.05 & $\begin{array}{l}2.2 \\
3.0\end{array}$ & $\begin{array}{l}480 \\
578\end{array}$ & $\begin{array}{l}0.20 \\
0.13\end{array}$ & 10 \\
\hline 0.10 & $\begin{array}{l}2.1 \\
3.3\end{array}$ & $\begin{array}{r}1529 \\
710\end{array}$ & $\begin{array}{l}0.06 \\
0.14\end{array}$ & 0 \\
\hline 0.227 & $\begin{array}{l}1.4 \\
1.9\end{array}$ & $\begin{array}{l}310 \\
236\end{array}$ & $\begin{array}{l}0.33 \\
0.42\end{array}$ & \\
\hline 0.25 & $\begin{array}{l}1.8 \\
2.5\end{array}$ & $\begin{array}{l}116 \\
118\end{array}$ & $\begin{array}{l}0.86 \\
0.85\end{array}$ & \\
\hline 0.275 & 1.6 & $\begin{array}{l}131 \\
131\end{array}$ & $\begin{array}{l}0.77 \\
0.77\end{array}$ & \\
\hline 0.302 & 2.4 & 111 & 0.90 & 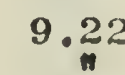 \\
\hline 0.333 & $\begin{array}{l}1.2 \\
1.9\end{array}$ & $\begin{array}{r}69 \\
91\end{array}$ & $\begin{array}{l}1.00 \\
1.45 \\
1.10\end{array}$ & 10. \\
\hline
\end{tabular}

$17.8^{\circ} \mathrm{C}$

\begin{tabular}{|c|c|c|c|c|}
\hline 0.025 & 2.6 & 7920 & 0.01 & 0.93 \\
\hline 0.05 & $\begin{array}{l}2: 0 \\
3: 3\end{array}$ & $\begin{array}{l}5902 \\
1742\end{array}$ & $\begin{array}{l}0.02 \\
0.66\end{array}$ & 1.95 \\
\hline 0.10 & 1.6 & 4236 & 0.02 & 3.75 \\
\hline 0.227 & & & $\begin{array}{l}0: 005 \\
0.43\end{array}$ & 7.95 \\
\hline 0.25 & $\begin{array}{l}1.7 \\
1.5 \\
1.6\end{array}$ & $\begin{array}{l}299 \\
121 \\
216\end{array}$ & $\begin{array}{l}0.33 \\
0.83 \\
0.46\end{array}$ & 8.72 \\
\hline$\underset{n}{0.275}$ & $\begin{array}{l}1.5 \\
1.6\end{array}$ & $\begin{array}{r}108 \\
87\end{array}$ & $\begin{array}{l}0.93 \\
1.16\end{array}$ & 9.51 \\
\hline 0.302 & $\begin{array}{l}1.7 \\
1.7\end{array}$ & $\begin{array}{l}61 \\
61\end{array}$ & $\begin{array}{l}1.64 \\
1.64\end{array}$ & $10 \cdot 3^{37}$ \\
\hline n & 1.7 & 53 & 1.88 & \\
\hline$n$ & 0.9 & 40 & 2.50 & \\
\hline 0.333 & 1.4 & $\begin{array}{l}65 \\
50\end{array}$ & 1.54 & 11.37 \\
\hline
\end{tabular}

$22.8^{\circ} \mathrm{C}$ 。
0.025
$1: 8$
$8520 \pm$
0.01
0.02
1.15 three days the temperature was raised to $18^{\circ}$ to $20^{\circ} \mathrm{C}$. 


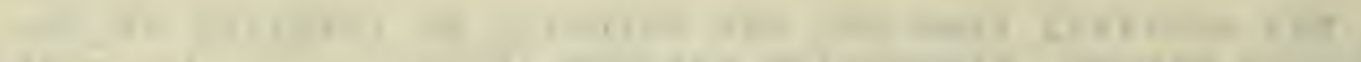

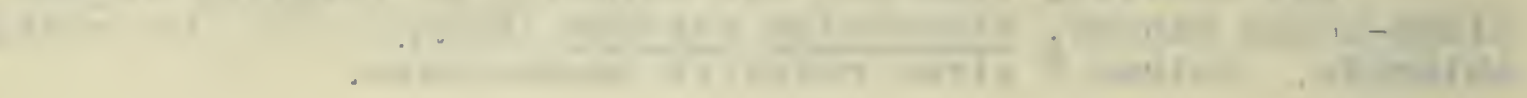

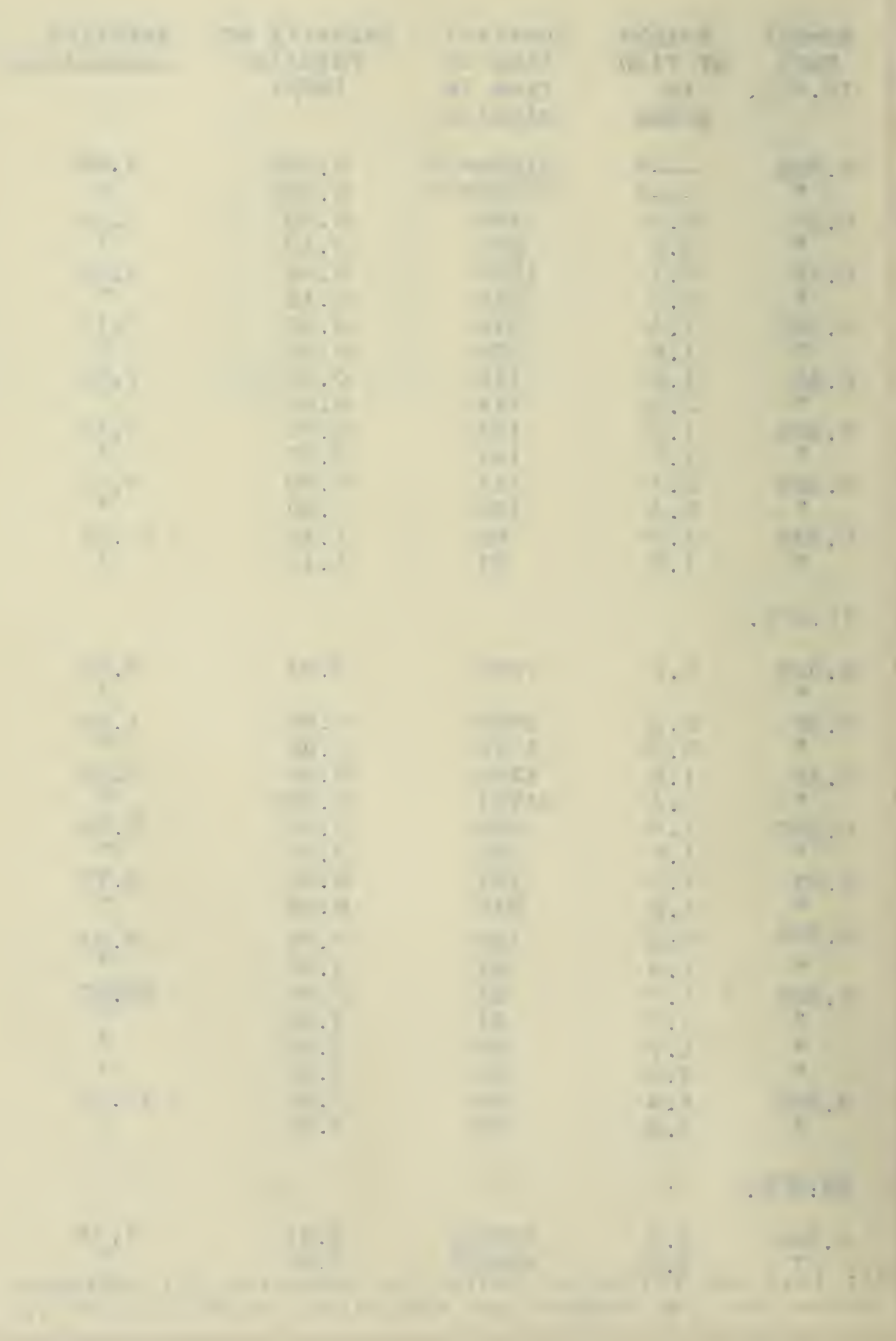




\section{TABLE III Continued.}

\begin{tabular}{|c|c|c|c|c|}
\hline Normal & Weight & Survival & Velocity of & Relat \\
\hline $\mathrm{NaCl}$ & of $\mathrm{flsh}$ & time of & fatality & condu \\
\hline $22.8^{\circ} \mathrm{C}$. & in & fish in & $100 / t$ & \\
\hline & Erams & minutes & & \\
\hline 0,05 & $1: 6$ & $14400 \pm$ & $0: 002$ & 2.18 \\
\hline 0.10 & 2.4 & $\begin{array}{r}3120 \\
575\end{array}$ & 0.03 & 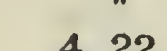 \\
\hline & 2.3 & $7920 \pm$ & $0: 01$ & \\
\hline 0.227 & 2.2 & 69 & 1.45 & 8.95 \\
\hline & $2: 4$ & 106 & 0.94 & \\
\hline 0.25 & 1.4 & 73 & 1.37 & 9.71 \\
\hline & $1: 9$ & 73 & 1.37 & \\
\hline 0.275 & 1.8 & 26 & 3.85 & 10.56 \\
\hline & 1.8 & 36 & 2.77 & \\
\hline 0.302 & $1: 8$ & 23 & 4.35 & 11.51 \\
\hline 0.333 & $1: 8$ & 23 & 4.35 & \\
\hline 0.333 & $\begin{array}{l}1.8 \\
2.2\end{array}$ & $\begin{array}{l}24 \\
19\end{array}$ & $\begin{array}{l}4.17 \\
5.27\end{array}$ & \\
\hline & & & & \\
\hline
\end{tabular}

$27.8^{\circ} \mathrm{C}$

\begin{tabular}{|c|c|c|c|c|}
\hline 0.025 & $\begin{array}{l}1.8 \\
2.3\end{array}$ & $\begin{array}{c}1400 \neq \\
480 t\end{array}$ & $\begin{array}{l}0.07 \\
0.21\end{array}$ & 1.23 \\
\hline 0.05 & $1: 7$ & $\begin{array}{r}1400 \pm \\
480 \pm\end{array}$ & $\begin{array}{l}0.07 \\
0.21\end{array}$ & 2.42 \\
\hline 0.10 & $\begin{array}{l}1.5 \\
1.8\end{array}$ & $\begin{array}{l}166 \\
123\end{array}$ & $\begin{array}{l}0.60 \\
0.81\end{array}$ & 4.63 \\
\hline $0.227:$ & $\begin{array}{l}1: 9 \\
1: 9\end{array}$ & $\begin{array}{l}50 \\
53\end{array}$ & $\begin{array}{l}2.00 \\
1: 89\end{array}$ & 9.76 \\
\hline 0.25 & $\begin{array}{l}1: 6 \\
2: 6\end{array}$ & $\begin{array}{l}40 \\
34\end{array}$ & $\begin{array}{l}2.50 \\
2.94\end{array}$ & 10.65 \\
\hline 0.275 & $1: 7$ & $\begin{array}{l}34 \\
34\end{array}$ & $\begin{array}{l}2.94 \\
2.94\end{array}$ & 11.60 \\
\hline 0.302 & $\begin{array}{l}1.5 \\
1.8\end{array}$ & $\begin{array}{l}14 \\
18\end{array}$ & $\begin{array}{l}7.15 \\
5.55\end{array}$ & 12.70 \\
\hline 0.333 & $\begin{array}{l}2.0 \\
2.5\end{array}$ & $\begin{array}{l}10 \\
17\end{array}$ & $\begin{array}{r}10: 00 \\
5.89\end{array}$ & 13.94 \\
\hline
\end{tabular}

$32.8^{\circ} \mathrm{C}$

\begin{tabular}{|c|c|c|c|c|}
\hline 0.025 & 2.0 & 64 & 1.56 & 1.37 \\
\hline$n$ & 2.4 & 64 & 1.53 & $n$ \\
\hline " & 1.6 & 129 & 0.77 & $n$ \\
\hline$n$ & 1.7 & 54 & $1: 85$ & $n$ \\
\hline 0.05 & $-\infty$ & 44 & 2.27 & 2.62 \\
\hline$n$ & $--\dot{\theta}$ & 44 & 2.27 & 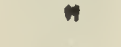 \\
\hline$\omega$ & 1.8 & 129 & 0.77 & $n$ \\
\hline * & 2.4 & 102 & 0.98 & $n$ \\
\hline 0.10 & 2.0 & $\begin{array}{r}54 \\
\end{array}$ & 1.85 & 5.03 \\
\hline
\end{tabular}


-

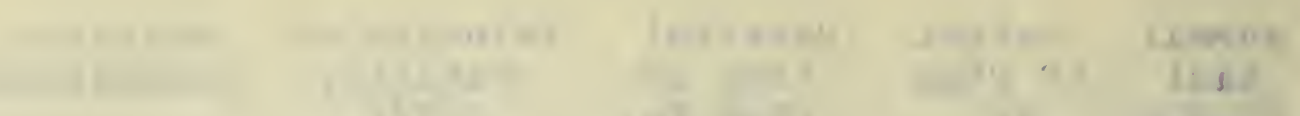

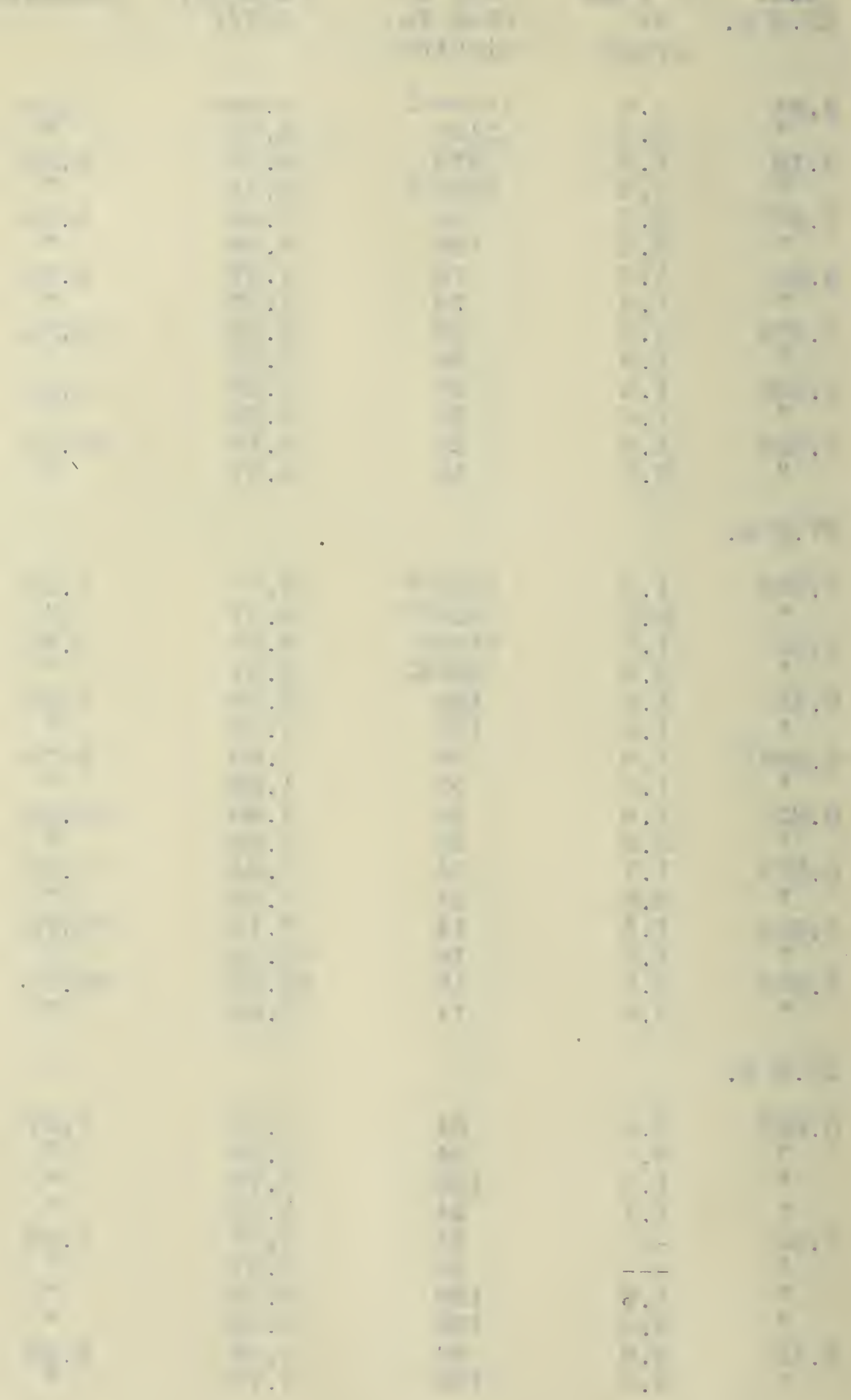


The survival time and the velocity of ratality of the blunt-nosed minnow, Pimeplales notatus (Rafinesque), in magnesIum chloride. Column 5 gives relative conductance.

\begin{tabular}{|c|c|c|c|}
\hline $\begin{array}{l}\text { Normal } \\
\text { MgC12 } \\
12.8^{\circ} \mathrm{C}\end{array}$ & $\begin{array}{l}\text { Weight } \\
\text { of fish } \\
\text { in } \\
\text { grams }\end{array}$ & $\begin{array}{l}\text { Survival } \\
\text { time of } \\
\text { fish in } \\
\text { minutes }\end{array}$ & $\begin{array}{c}\text { Velocity of } \\
\text { fatality } \\
100 / t\end{array}$ \\
\hline 0.025 & $\begin{array}{l}1.6 \\
2: 5\end{array}$ & $\begin{array}{r}840 * \\
7860 *\end{array}$ & $\begin{array}{l}0.12 \\
0.01\end{array}$ \\
\hline 0.05 & $\begin{array}{l}2.9 \\
3.5\end{array}$ & $\begin{array}{l}7814 * \% \\
3389 * \%\end{array}$ & $\begin{array}{l}0.01 \\
0.03\end{array}$ \\
\hline 0.10 & $\begin{array}{l}2.1 \\
2.3\end{array}$ & $\begin{array}{r}6180 * \\
23640 *\end{array}$ & $\begin{array}{l}0.02 \\
0.004\end{array}$ \\
\hline 0.227 & $\begin{array}{l}1.7 \\
1.9\end{array}$ & $\begin{array}{l}86 \\
78\end{array}$ & $\begin{array}{l}1.16 \\
1.28\end{array}$ \\
\hline 0.25 & $\begin{array}{l}2.0 \\
3.5\end{array}$ & $\begin{array}{l}105 \\
112\end{array}$ & $\begin{array}{l}0.95 \\
0.89\end{array}$ \\
\hline $\begin{array}{l}0.275 \\
0.302\end{array}$ & $\begin{array}{l}1.6 \\
1.6 \\
1.9\end{array}$ & $\begin{array}{l}115 \\
72 \\
53\end{array}$ & $\begin{array}{l}0.87 \\
1.39 \\
1.89\end{array}$ \\
\hline 0.333 & $\begin{array}{l}1.5 \\
1.7\end{array}$ & $\begin{array}{r}69 \\
100\end{array}$ & $\begin{array}{l}1.43 \\
1.00\end{array}$ \\
\hline
\end{tabular}

$17.8^{\circ} \mathrm{C}$

\begin{tabular}{|c|c|c|c|c|}
\hline 0.025 & $\begin{array}{l}2.1 \\
2.5\end{array}$ & $\begin{array}{l}16560 * * \\
27360 *\end{array}$ & $\begin{array}{l}0.006 \\
0.003\end{array}$ & $\begin{array}{l}0.98 \\
0: 98\end{array}$ \\
\hline 0.05 & 2.4 & $28800 * *$ & 0,063 & 1:8ิ \\
\hline & 2.5 & $28800 * *$ & 0.003 & \\
\hline 0.10 & 1.8 & 4236 & 0.02 & 3.4 \\
\hline & 3.5 & 15000 & $0: 006$ & \\
\hline 0.227 & $\begin{array}{l}1.5 \\
1.9\end{array}$ & $\begin{array}{r}173 \\
99\end{array}$ & $\begin{array}{l}0.58 \\
1.01\end{array}$ & 7 \\
\hline 0.25 & 1.6 & 114 & 0.88 & 7.8 \\
\hline & 1.7 & 78 & 1.28 & \\
\hline 0.275 & 0.6 & 56 & $1: 79$ & 8.1 \\
\hline 0.302 & 0.6 & 57 & 1.75 & 9.2 \\
\hline & 3.7 & 65 & 1.54 & \\
\hline 0.333 & 0.9 & 40 & 2.50 & 10.12 \\
\hline & 1.7 & 53 & $1: 89$ & \\
\hline
\end{tabular}

$22.8^{\circ} \mathrm{C}$

$\begin{array}{ccclc}0.025 & 1.8 & 4800 \pm & 0.02 & 1.05 \\ 0.05 & 2.0 & 6200 \pm & 0.016 & \\ 0.10 & 2.5 & 3120 \pm & 0.03 & 2.08 \\ 0.10 & 2.6 & 3120 \pm & 0.03 & \\ & 2.7 & 160 \pm & 0.62 & 3.84\end{array}$




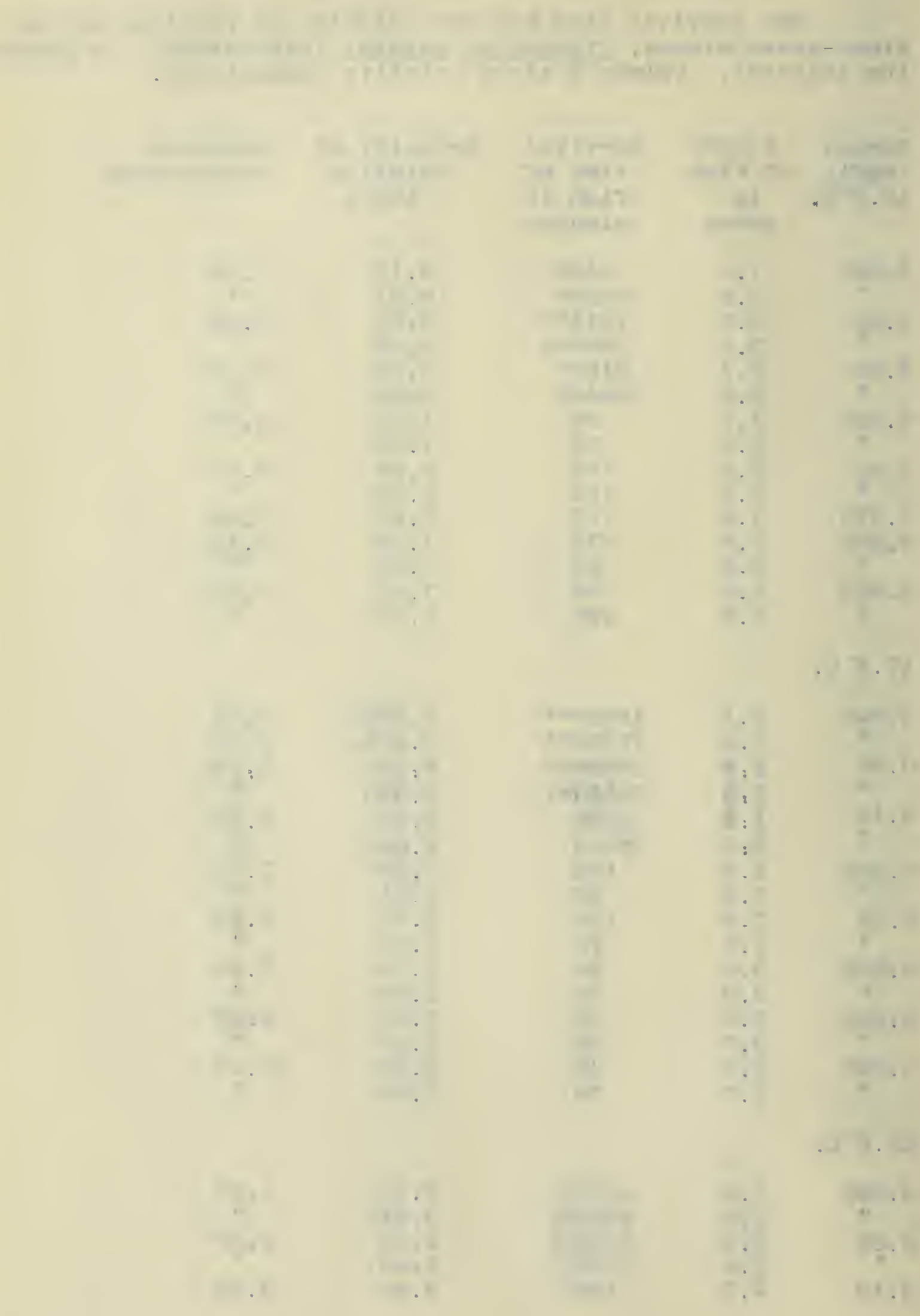


TABLE IV Continued.

Normal Weight Surviral Velocity of Relative

$\mathrm{MgCl}_{2}$ of fish time of $22.8^{\circ} \mathrm{C}$. In Iish in grams minutes

fotality $100 / t$

$\begin{array}{rr}101 & 0.99 \\ 89 & 1.12 \\ 73 & 1.37 \\ 73 & 1.37 \\ 43 & 2.33 \\ 51 & 1.96 \\ 35 & 2.86 \\ 35 & 2.86 \\ 32 & 3.12 \\ 44 & 2.25\end{array}$

$27.8^{\circ} \mathrm{C}$

0.025

$2: 1$

0.05

1.3

0.10

0.227

0.25

0.275

0.302

0.3 .33

1.4

1.9

1.7

1.9

1.8

1.8

1:6

$1: 8$

$1: 7$

1.8

44

1709

2880

2763

$480 \neq$

516

120

52

70

16

40

34

18

23

27

12

25

$32.8^{\circ} \mathrm{C}$

$\begin{array}{rr}0.05 \% & 1.9 \\ & 1.8 \\ & 3.4 \\ 0.025 & 3.5 \\ m & 2.0 \\ m & 3.3 \\ 0.10 & 3.4 \\ & 3.5 \\ & 2.0 \\ & 2.0\end{array}$

166

40

52

106

66

110

51

6

108
$0: 60$

$2: 50$

1. 91

0.94

3.30

0.90

1.96

16.66

2.70

0.93
0.06

0.035

1. 17

$0: 035$

0.21

0.198

0.83

1:92

1.43

6.25

2.50

2.94

5.66

$4: 35$

3.70

$8: 38$

4.00

2. 23

4. 22

$8 \cdot 74$

9.48

10. 27

$12.7 ?$

$12: 12$

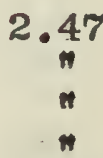

1. 29

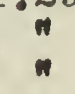

$-\cdots$ 

TABLE V .

The surrival time and the velocity of fatality of the blunt-nosed minnow, Plmephales notatus Raf;; ;n calcium chloride. Column 5 gives relative conductance.

Normal Weight Surviral Velocity of Relative

$\mathrm{CaCl}_{2}$ of fish time of catality condictance
$12.8^{\circ} \mathrm{C}$. in

grams

minutes

\begin{tabular}{|c|c|c|c|c|}
\hline 0.025 & $\begin{array}{l}2.5 \\
3.1\end{array}$ & $\begin{array}{l}15600 * \pm \\
15600 * \pm\end{array}$ & $\begin{array}{l}0.006 \\
0.006\end{array}$ & 0.899 \\
\hline 0.05 & 2.6 & $10560 *$ & 0.009 & $1 \cdot 64$ \\
\hline 0.10 & $\begin{array}{l}3.7 \\
---\end{array}$ & $\begin{array}{l}4311 \\
7120=\end{array}$ & $\begin{array}{l}0.02 \\
0.01\end{array}$ & 3.00 \\
\hline 0.227 & $\begin{array}{l}1.6 \\
3: 0\end{array}$ & $\begin{array}{r}351 \\
1071\end{array}$ & $\begin{array}{l}0.28 \\
0.09\end{array}$ & 6.51 \\
\hline 0.25 & 1.9 & 118 & 0.86 & 7.05 \\
\hline 0.275 & 2.0 & $\begin{array}{l}90 \\
75\end{array}$ & $\begin{array}{l}1.11 \\
1: 34\end{array}$ & \\
\hline 0.302 & 1.0 & 66 & 1.52 & 8.51 \\
\hline 0.333 & $\begin{array}{l}3.5 \\
1.6 \\
1.9\end{array}$ & $\begin{array}{l}87 \\
86 \\
58\end{array}$ & $\begin{array}{l}1.15 \\
1.16 \\
1.72\end{array}$ & 9.22 \\
\hline
\end{tabular}

$17.8^{\circ} \mathrm{C}$

\begin{tabular}{|c|c|c|c|c|}
\hline 0.025 & $\begin{array}{l}2: 3 \\
3: 3\end{array}$ & $\begin{array}{l}6660 * * t \\
6900 * \text { t }\end{array}$ & $\begin{array}{l}0.015 \\
0.014\end{array}$ & 0.98 \\
\hline 0.05 & $\begin{array}{l}2.5 \\
2.6\end{array}$ & $\begin{array}{l}9360 * \% \\
5040 * *\end{array}$ & $\begin{array}{l}0.011 \\
0.02\end{array}$ & 1.84 \\
\hline 0.10 & $\begin{array}{l}1: 7 \\
2.5\end{array}$ & $\begin{array}{l}4490 \\
4430\end{array}$ & $\begin{array}{l}0.02 \\
0.02\end{array}$ & 3.53 \\
\hline 0.227 & $\begin{array}{l}1.5 \\
2.0\end{array}$ & $\begin{array}{l}158 \\
293\end{array}$ & $\begin{array}{l}0.63 \\
0.34\end{array}$ & 7. .34 \\
\hline 0.25 & $\begin{array}{l}1.5 \\
1.9\end{array}$ & $\begin{array}{l}202 \\
117\end{array}$ & $\begin{array}{l}0.49 \\
0.85\end{array}$ & 8.01 \\
\hline 0.275 & $\begin{array}{l}1.3 \\
1.7\end{array}$ & $\begin{array}{l}56 \\
65\end{array}$ & $\begin{array}{l}1: 79 \\
1: 54\end{array}$ & 8.53 \\
\hline 0.302 & $\begin{array}{l}1.3 \\
1.5\end{array}$ & $\begin{array}{l}61 \\
53\end{array}$ & $\begin{array}{l}1.64 \\
1.89\end{array}$ & 9.48 \\
\hline 0.333 & $\begin{array}{l}1.2 \\
1.5\end{array}$ & $\begin{array}{l}40 \\
32\end{array}$ & $\begin{array}{l}2.50 \\
3.13\end{array}$ & 10.50 \\
\hline
\end{tabular}

$22.8^{\circ} \mathrm{C}$

\begin{tabular}{|c|c|c|c|c|}
\hline 0.025 & 2.3 & 2580 & 0.04 & 1.14 \\
\hline & 2.6 & $7920 \pm$ & 0.01 & \\
\hline 0.05 & $\begin{array}{l}2.2 \\
2.3\end{array}$ & $\begin{array}{l}5760 \pm \\
1600 \pm\end{array}$ & $\begin{array}{l}0.027 \\
0.06\end{array}$ & $=-\infty$ \\
\hline 0.10 & 2.1 & $1140 \pm$ & 0.08 & 3.83 \\
\hline & 2.3 & 5915 & 0.016 & 8 \\
\hline 227 & 1.8 & 83 & $\begin{array}{r}1.37 \\
1.37\end{array}$ & 7 \\
\hline
\end{tabular}


and

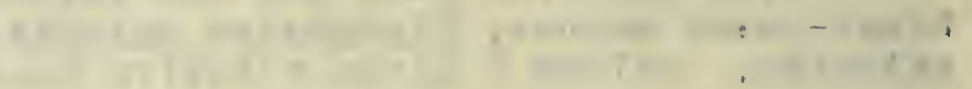

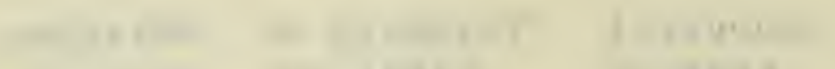
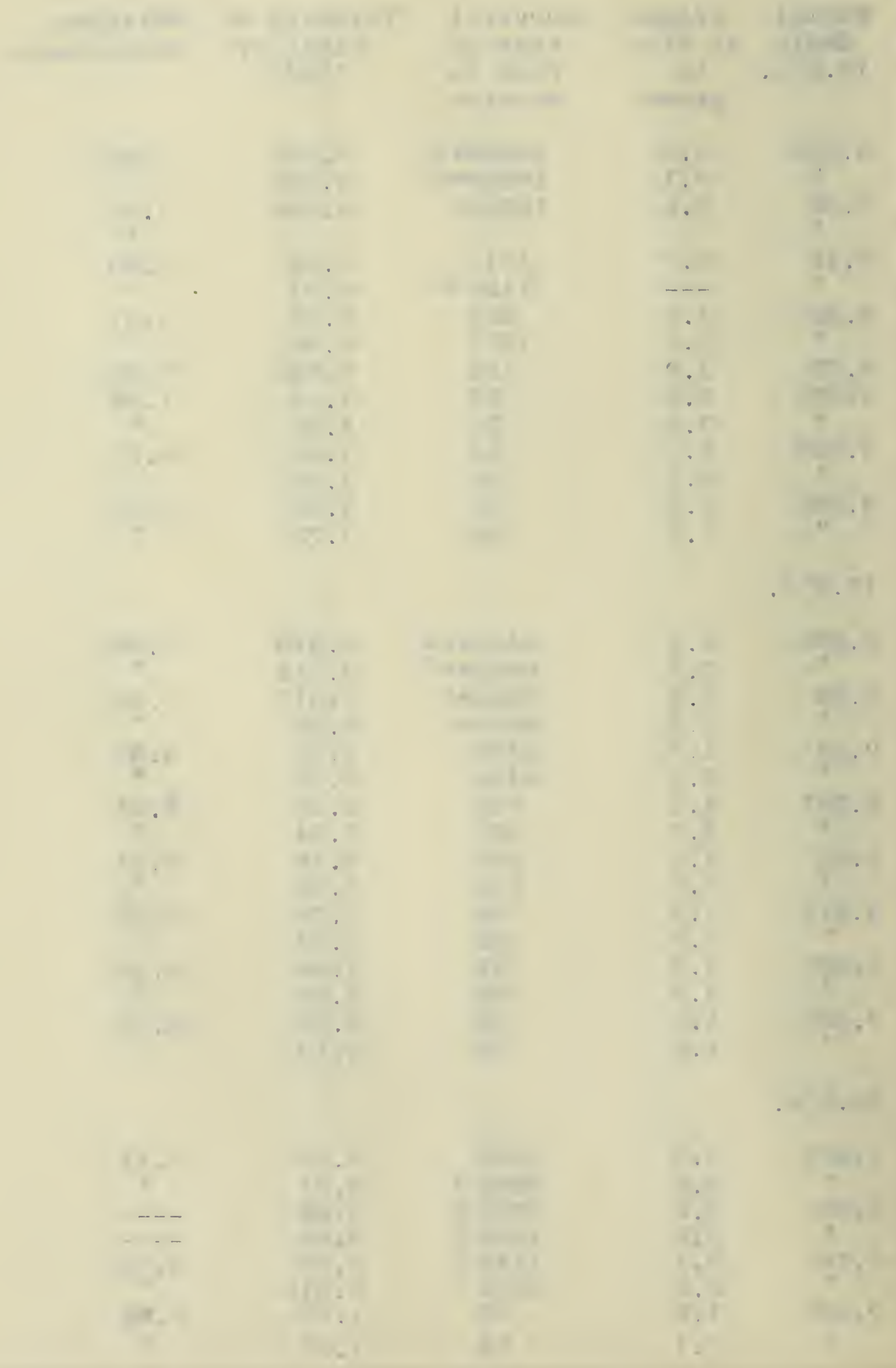
TABLE V Continued.

Normal Weight Survival Velocity of Relative $\begin{array}{cccc}\mathrm{CaCl} & \text { of } \mathrm{fish} & \mathrm{time} \text { of } & \text { fatality } \\ 22.8^{\circ} \mathrm{C} \text {. In } & \text { flsh in } & 100 / \mathrm{t} & \end{array}$ grams minutes

\begin{tabular}{|c|c|c|c|c|}
\hline 9,25 & $1: 3$ & 72 & $1: 39$ & 8.92 \\
\hline & $1: 5$ & 81 & $1: 23$ & \# \\
\hline 0.275 & $\begin{array}{l}1.5 \\
1.8\end{array}$ & $\begin{array}{l}55 \\
52\end{array}$ & $\begin{array}{l}1: 82 \\
1: 89\end{array}$ & 9.52 \\
\hline 0.302 & $2: 0$ & 30 & 3.33 & 10.60 \\
\hline$n$ & $2: 3$ & 47 & 2.13 & n \\
\hline 0.333 & 1.3 & 32 & 3.13 & \\
\hline & 1.9 & 26 & 3.85 & \\
\hline
\end{tabular}

$22.8^{\circ} \mathrm{C}$

\begin{tabular}{|c|c|c|c|c|}
\hline 0.025 & $\begin{array}{l}1.9 \\
2.2\end{array}$ & $\begin{array}{r}2800 \\
580\end{array}$ & $\begin{array}{l}0.035 \\
0.17\end{array}$ & 1. 19 \\
\hline 0.05 & 2.0 & $480 \pm$ & 0.21 & 2.29 \\
\hline & 1.8 & $1200 \pm$ & 0.08 & \\
\hline & 2.3 & $1200 t$ & $0: 08$ & \\
\hline$\omega$ & 3.4 & $480=$ & 0.21 & $n$ \\
\hline 0.10 & 2.0 & 248 & 0.40 & 4.29 \\
\hline & $2: 3$ & 1100 & 0.09 & \\
\hline 0.227 & 1.8 & 60 & $1: 66$ & 8.3 \\
\hline & $2: 2$ & 49 & $2: 04$ & \\
\hline 0.25 & $1: 2$ & 40 & 2.50 & 9.83 \\
\hline & 2.6 & 34 & $2: 94$ & 11.60 \\
\hline 0.275 & $\begin{array}{l}1.7 \\
2.0\end{array}$ & $\begin{array}{l}34 \\
34\end{array}$ & $\begin{array}{l}2.94 \\
2: 94\end{array}$ & $11 \cdot 60$ \\
\hline 0.302 & $\begin{array}{l}1: 5 \\
1.8\end{array}$ & $\begin{array}{l}14 \\
18\end{array}$ & $\begin{array}{l}7.15 \\
5.55\end{array}$ & 12.93 \\
\hline 0.333 & $\begin{array}{l}2.0 \\
2.5\end{array}$ & $\begin{array}{l}10 \\
17\end{array}$ & $\begin{array}{r}10.00 \\
5.89\end{array}$ & 13.9 \\
\hline
\end{tabular}

$32.8^{\circ} \mathrm{C}$

\begin{tabular}{|c|c|c|c|c|}
\hline 0.025 & $1: 6$ & 84 & $1: 19$ & 1.32 \\
\hline$n$ & 1.8 & 81 & $1: 23$ & " \\
\hline ต & 2.0 & 64 & 1.58 & " \\
\hline " & 2.5 & 46 & $2: 17$ & T \\
\hline 0.05 & 1.7 & 66 & $1: 51$ & 2.51 \\
\hline " & $1: 6$ & 84 & 1.19 & n \\
\hline$\omega$ & 1.8 & 96 & 1604 & " \\
\hline$n$ & 2.0 & 87 & 1.15 & $n$ \\
\hline 0.10 & 1.7 & 49 & 2.04 & $4: 49$ \\
\hline$n$ & 2.2 & 179 & 0.56 & \\
\hline 0.227 & 1.6 & 37 & 2.70 & 9.54 \\
\hline & 1.7 & 51 & 1.96 & \\
\hline
\end{tabular}




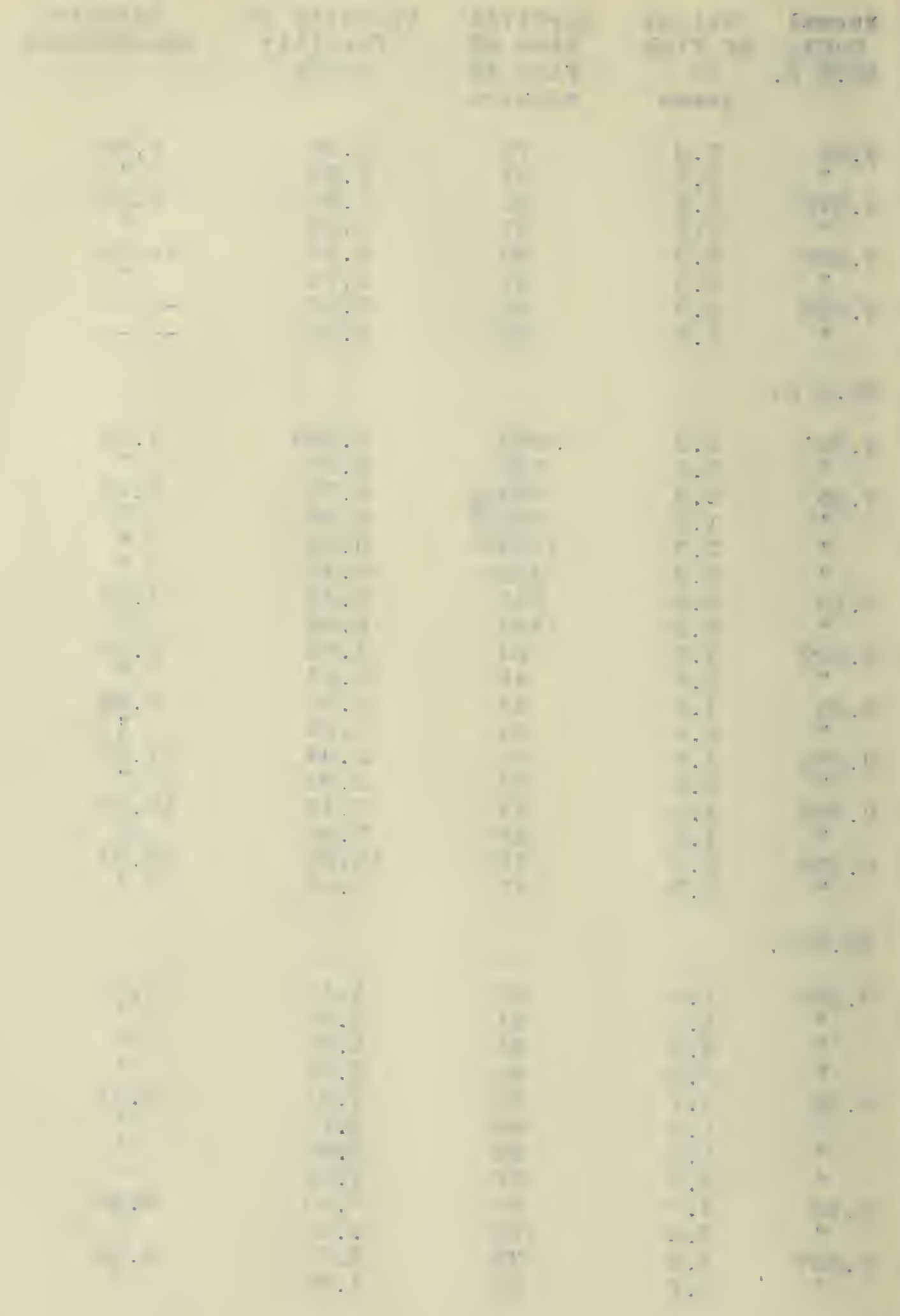


TABLE VI.

The surrival time and the velocity of fatality of the blunt-nosed minnow, pimephales notatus Raf:; in barium chloride. Column 5 gives relative conductance.

Normal Weight Survival Velocity of Relative

$\mathrm{BaCl}_{2}$ of fish tim of fatality conductance

$12.8^{\circ} \mathrm{C}$. In fish in $100 / \mathrm{t}$

grams ininutes

\begin{tabular}{|c|c|c|c|c|}
\hline 0.025 & $-\infty$ & 520然 & 0.19 & 0.82 \\
\hline & & $520 \pm$ & 0.19 & \\
\hline 0.05 & $\begin{array}{l}2.1 \\
2.2\end{array}$ & $\begin{array}{r}86 \\
120\end{array}$ & 1.16 & 1.61 \\
\hline 0.10 & 2.0 & $\begin{array}{r}120 \\
54\end{array}$ & $\begin{array}{l}0.85 \\
1.85\end{array}$ & 3.0 \\
\hline & 2.0 & 54 & 1.85 & \\
\hline 0.227 & 1.9 & 31 & 3.23 & $6 . ?$ \\
\hline 0.25 & $\begin{array}{l}2.3 \\
2.0\end{array}$ & 36 & $\begin{array}{l}2.78 \\
1.90\end{array}$ & 9 \\
\hline 0.25 & 3.5 & $\begin{array}{l}35 \\
37\end{array}$ & $\begin{array}{l}1.90 \\
1.82\end{array}$ & \\
\hline 0.275 & 1.5 & 33 & 2.20 & .6 \\
\hline$"$ & 1.7 & 33 & 2.20 & \\
\hline 0.302 & 1.8 & 26 & 2.57 & .30 \\
\hline " & 1.8 & 26 & 2.57 & \\
\hline 0.333 & 1.6 & 20 & 4.50 & .07 \\
\hline & 1.9 & 23 & 4.35 & \\
\hline
\end{tabular}

$17.8^{\circ} \mathrm{C}$.

$\begin{array}{lll}0.025 & 0.9 & 135\end{array}$

$3.4 \quad 135$

$0.05 \quad 1.1$

1.2

$0.227 \quad 0.5$

2.0

0.25

0.8

4.2

0.275

0.9

4.2

$0.302 \quad 0.6$

0.6

0.333

0.5

2.7

$22.8^{\circ} \mathrm{C}$

$\begin{array}{rcccc}0.025 & 2.2 & 420 \pm & 0.24 & 1.09 \\ 0.05 & 1.5 & 69 & 1.45 & 2.18 \\ \text { " } & 2.2 & 69 & 1.45 & \text { " } \\ \text { " } & 2.3 & 71 & 1.41 & \text { " } \\ 0.10 & 3.0 & 40 & 2.50 & 3.82 \\ \text { " } & 1.4 & 32 & 3.13 & 3.3\end{array}$

0.74

0.74

0.93

1.04

7.14

$3: 13$

$5: 26$

4.55

4.77

5.88

5.88

5.88

17

6
14

16.66

7.14

\section{4}

0.95

1. 81

7.23

7.88

8.51

9.34

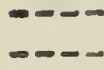



TABLE VI Continued.

Normal Welght Survival Velocity of Relative

$\mathrm{BaCl}_{2}$ of fish time of

$22.8^{\circ} \mathrm{C}$. in fish in

Patality conductance

grams

minutes

$\begin{array}{lrrrr}0.227 & 1.6 & 13 & 7.69 & 7.99 \\ 0.25 & 1.7 & 13 & 7.69 & n \\ n & 1.5 & 11 & 9.09 & 8.65 \\ 0.275 & 2.0 & 11 & 9.09 & n \\ n & 2.2 & 9 & 11.10 & 9.38 \\ 0.302 & 2.3 & 8 & 12.50 & n \\ n & 2.0 & 10 & 10.00 & 10.36 \\ 0.333 & 2.3 & 10 & 10.00 & n \\ n & 1.8 & 10 & 10.00 & 11.27 \\ & 2.3 & 7 & 7.43 & \end{array}$

$27.8^{\circ} \mathrm{C}$

\begin{tabular}{|c|c|c|c|c|}
\hline 0.025 & 2.6 & 73 & 1.37 & .18 \\
\hline & 3.3 & 42 & 2.38 & \\
\hline 0.05 & 2.2 & $39 \pm$ & 2.56 & 21 \\
\hline & 3.4 & $39 I$ & 2.56 & \\
\hline 0.10 & 2.0 & 7.5 & 13.35 & 22 \\
\hline & 3.5 & 6.5 & $15: 39$ & " \\
\hline 0.227 & 2.2 & 6.5 & 15.38 & .81 \\
\hline & 2.2 & 6.5 & $15: 38$ & \\
\hline 0.25 & 2.2 & 5.6 & 18.19 & 62 \\
\hline & 3.5 & 5.5 & 18.91 & \\
\hline 0.275 & 2.0 & 4.5 & 22.22 & \\
\hline & 2.0 & 7.5 & 13.35 & \\
\hline 0.302 & 2.1 & 4.5 & $22: 22$ & 11.48 \\
\hline & 2.3 & 4.5 & 22.22 & \\
\hline 0.333 & 1.5 & 3.5 & 28.59 & 12.37 \\
\hline & 1.6 & 3.5 & 28.59 & \\
\hline
\end{tabular}

$32.8^{\circ} \mathrm{C}$.

$\begin{array}{lllll}0.025 & 1.5 & 20 & 5.00 & 1.30 \\ 0.05 & 2.0 & 13 & 7.69 & \\ 0.05 & 1.6 & 50 & 2.00 & 5.30 \\ n & 1.7 & 11 & 9.09 & \end{array}$


+1 19

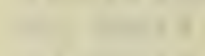
$+1+2+1$ the at:
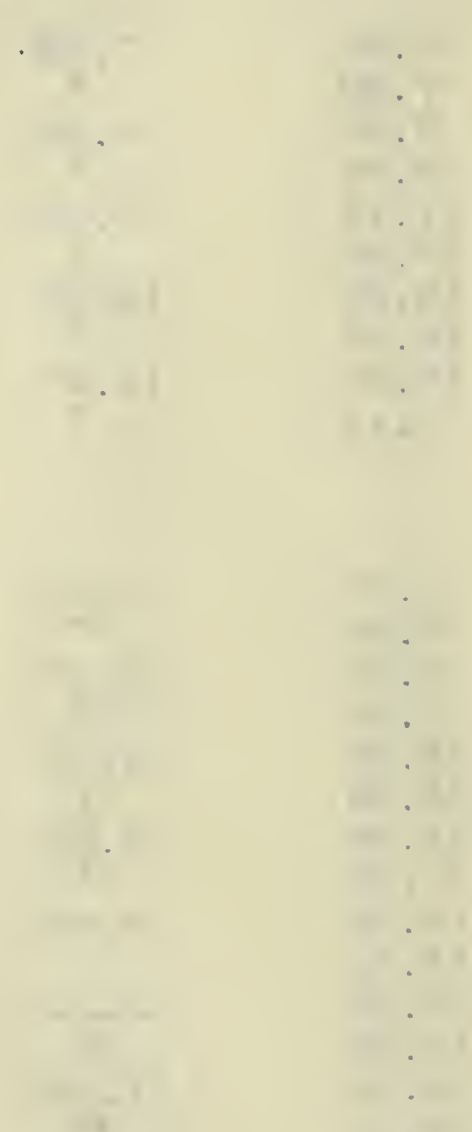

$\sqrt{2}$

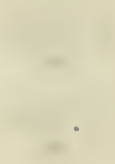$$
\sqrt{2}+x^{2}
$$
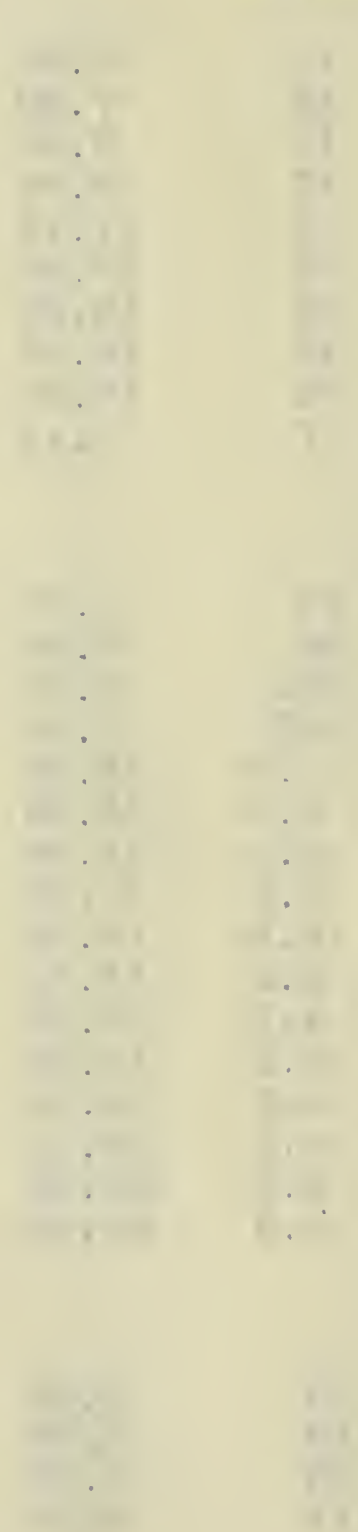
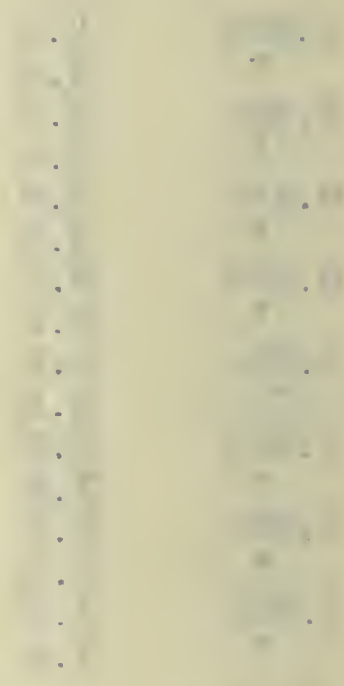

- . 
The ratio of increase in toxicity of electrolytes to the blunt-nosed minnor, Plmephales notatus , Raf, ,, with an increase of 10 degrees centigrade.

Substance Noraml $12.8^{\circ}$ to $17.8^{\circ}$ to $22.8^{\circ}$ to $22.8^{\circ} \mathrm{C} . \quad 27.8^{\circ} \mathrm{C} . \quad 32.8^{\circ} \mathrm{C}$.

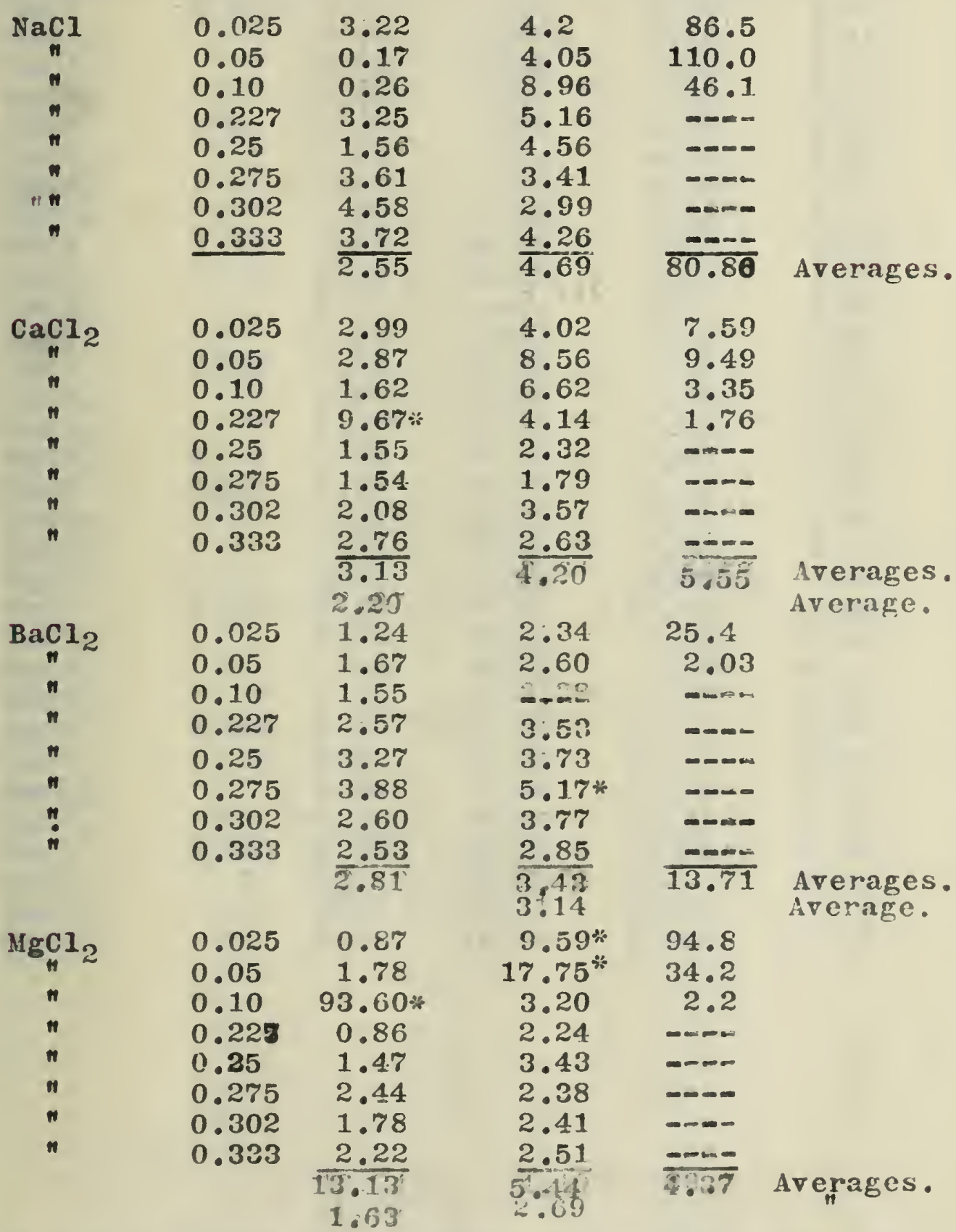

The ratios marked with an asterisk (*) have been omitted in the second set of averages. 


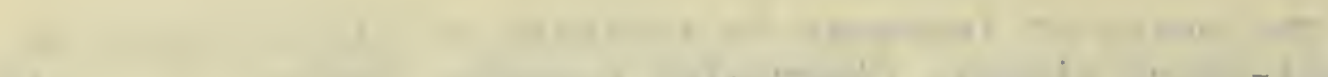

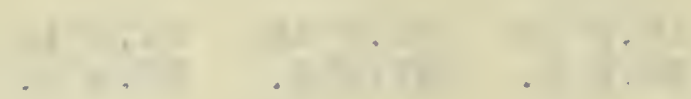

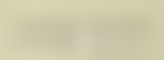

45
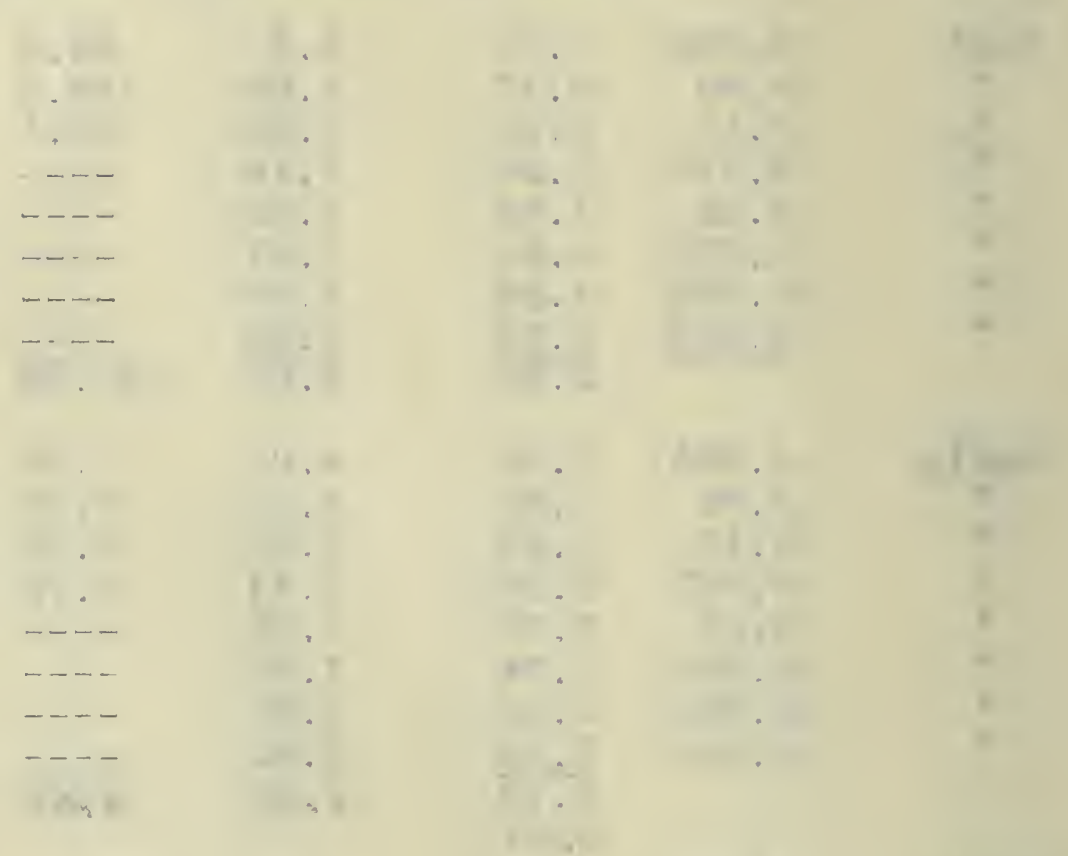

$-\cdots$

as
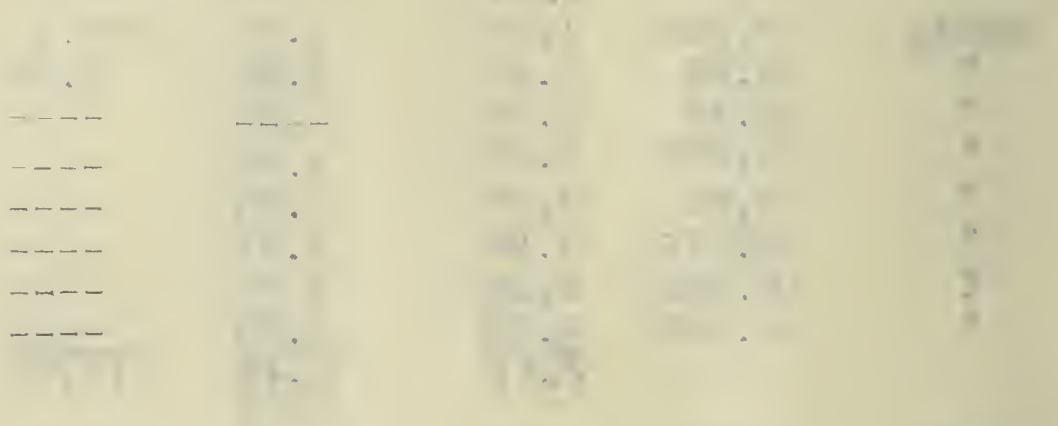

$+$
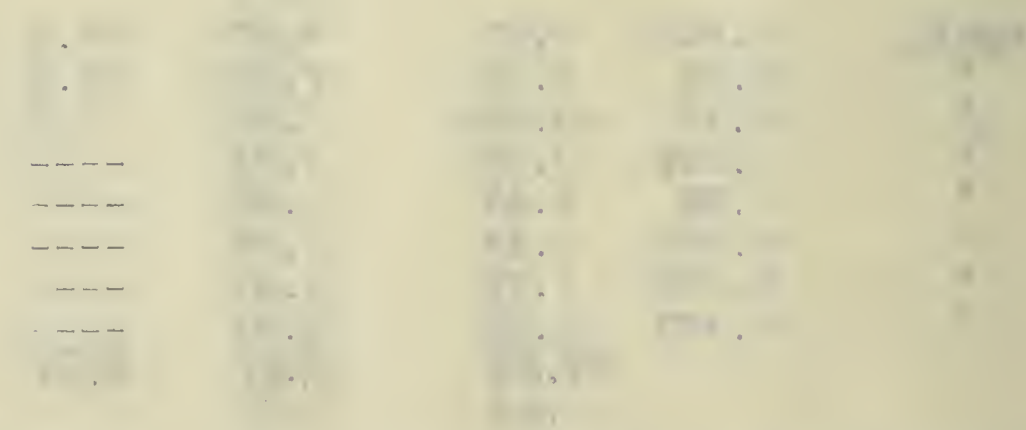

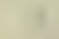
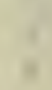
TABLE VIII.

The relative conductance of $\mathrm{NaCl}, \mathrm{CaCl}_{2}, \mathrm{BaCl}_{2}$, and $\mathrm{IgCl}_{2}$.

Substance Normal $12.8^{\circ} \mathrm{C}, 17.8^{\circ} \mathrm{C} .22 .8^{\circ} \mathrm{C} .27 .8^{\circ} \mathrm{C} .32 .8^{\circ} \mathrm{C}$.

\begin{tabular}{|c|c|c|c|c|c|c|}
\hline $\mathrm{NaCl}$ & 0.025 & 0.91 & 1.00 & 1.15 & 122 & 19 \\
\hline $\mathrm{CaCl}_{2}$ & $n$ & 0.90 & 0.985 & 1.14 & 1.19 & $\begin{array}{l}1.37 \\
1.37\end{array}$ \\
\hline $\mathrm{BaCl}_{2}$ & n & 0.82 & 0.95 & $1: 09$ & 1.18 & 1.30 \\
\hline $\mathrm{MgCl}_{2}$ & $n$ & 0.85 & 0.98 & 1.05 & 1.17 & 1.29 \\
\hline $\mathrm{NaCl}^{2}$ & 0.05 & 1.66 & 1.95 & 2.18 & 2.42 & 2.62 \\
\hline $\mathrm{CaCl}_{2}$ & " & 1.64 & 1.84 & $-\cdots$ & 2.29 & 2.51 \\
\hline $\mathrm{BaEI}_{2}$ & $n$ & 1.61 & 1.81 & 2.18 & 2.21 & 2.47 \\
\hline $\mathrm{MgCl}_{2}$ & N & 1.60 & 1.82 & 2.04 & 2.23 & 2.47 \\
\hline $\mathrm{NaCl}$ & 0.10 & 3.33 & 3.75 & 4.22 & 4.63 & 5.03 \\
\hline $\mathrm{CaCl}_{2}$ & $"$ & 3.00 & 3.53 & 3.83 & 4.29 & 4.60 \\
\hline $\mathrm{BaCl}_{2}^{\sim}$ & $"$ & 3.01 & - & 3.82 & 4.22 & \\
\hline $\mathrm{MgCl}_{2}$ & $n$ & 3.06 & 3.44 & 3.84 & 4.22 & - \\
\hline $\mathrm{NaCl}^{\sim}$ & 0.227 & 7.12 & 7.95 & 8.95 & 9.76 & \\
\hline $\mathrm{CaCl}_{2}$ & $"$ & 6.51 & 7.34 & 7.85 & 8.80 & $-\ldots$ \\
\hline $\mathrm{BaCl}_{2}$ & $n$ & 6.37 & 7.23 & 7.99 & 8.81 & \\
\hline $\mathrm{MgCl}_{2}^{\sim}$ & 0." & 6.36 & 7.33 & 8.00 & 8.74 & -- \\
\hline $\mathrm{NaCl}$ & 0.25 & 7.72 & 8.72 & 9.71 & 10.66 & \\
\hline $\mathrm{CaCl}_{2}$ & $"$ & 7.05 & 8.01 & 8.92 & 9.83 & $m$ \\
\hline $\mathrm{BaCl}_{2}$ & $"$ & 6.98 & 7.88 & 8.65 & 9.62 & \\
\hline $\mathrm{NgCl}_{2}$ & $\pi$ & 6.90 & 7.85 & 8.00 & 9.48 & $\ldots$ \\
\hline $\mathrm{NaCl}$ & 0.275 & 8.48 & 9.51 & 10.66 & 11.60 & $-\infty$ \\
\hline $\mathrm{CaCl}_{2}$ & $"$ & 7.38 & 8.53 & 9.52 & 11.60 & \\
\hline $\mathrm{BaCl}_{2}$ & $\pi$ & 7.64 & 8.51 & 9.38 & $\cdots-\cdots$ & \\
\hline $\mathrm{NgCl}_{2}$ & רס & 7.49 & 8.44 & 9.36 & 10.27 & $\cdots$ \\
\hline $\mathrm{NaCl}$ & 0.302 & 9.22 & & 11.51 & 12.93 & $\cdots$ \\
\hline $\mathrm{CaCl}_{2}$ & $"$ & 8.51 & 9.48 & 10.60 & 12.93 & $\cdots$ \\
\hline $\mathrm{BaCl}_{2}$ & " & 8.30 & 9.34 & 10.36 & $1: .37$ & $\cdots$ \\
\hline $\mathrm{MgCl}_{2}$ & $"$ & 8.12 & 9.29 & 10.30 & 11.30 &.-- \\
\hline $\mathrm{NaCl}^{\sim}$ & 0.333 & 10.37 & 11.37 & 12.63 & 13.94 & $\cdots$ \\
\hline $\mathrm{CaCl}_{2}$ & $m$ & 9.22 & 10.50 & $-\infty-\infty$ & 13.94 & $\cdots$ \\
\hline $\mathrm{BaCl}_{2}$ & $n$ & 9.07 & $10-70$ & 11.27 & $=-10$ & $\cdots$ \\
\hline $\mathrm{MgCl}_{2}$ & & 8.94 & 10.12 & 11.20 & 12.12 & \\
\hline
\end{tabular}



TABLE $\mathbf{1} \mathrm{X}$.

The survival time and the relocity of fatality of the blunt-nosed minnor, Pimephales notatus Raf,, "in ammonIum chloride.

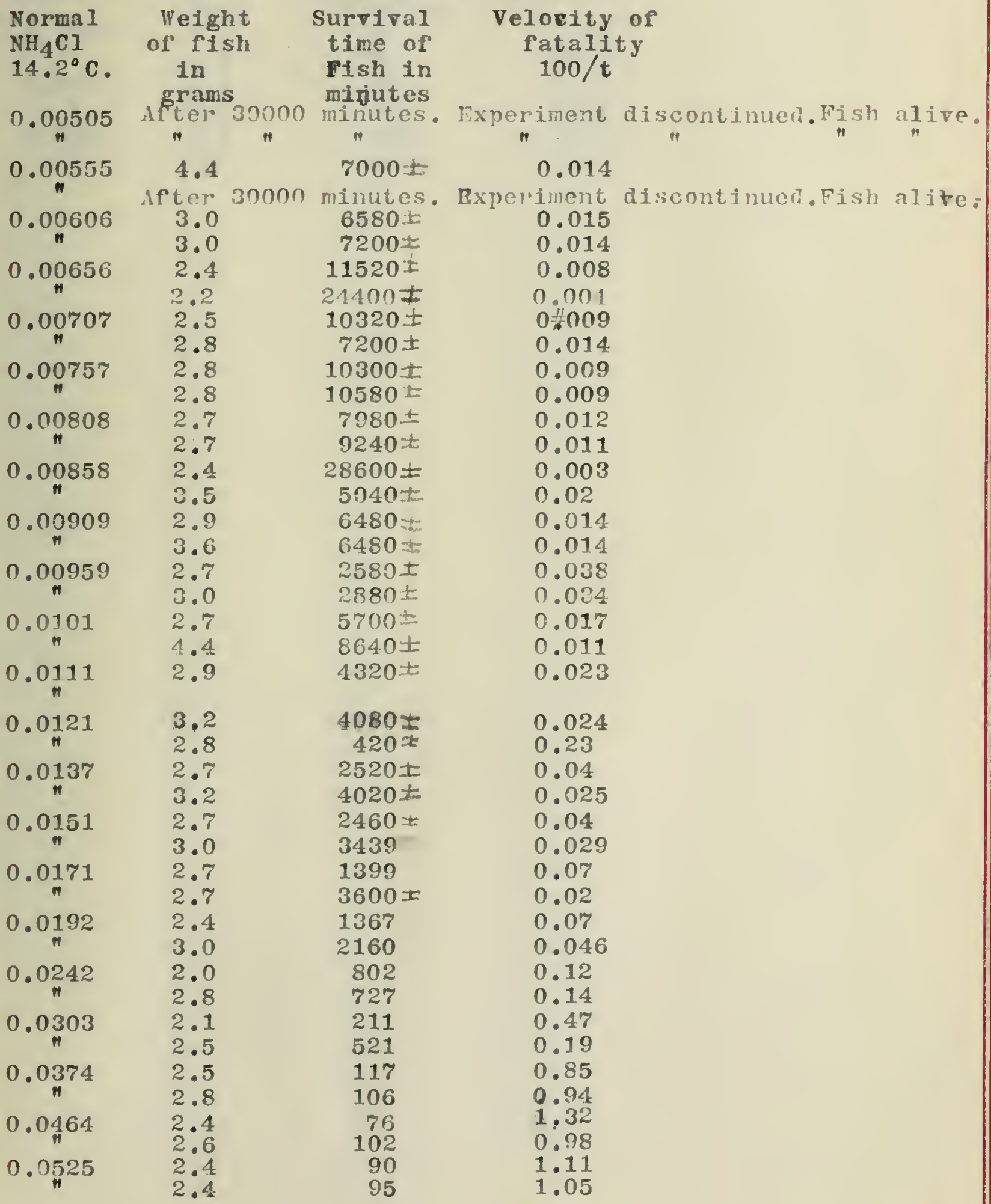



TABLE IX contined.

\begin{tabular}{|c|c|c|c|}
\hline Normal & Weight & Survival & Velocity of \\
\hline $\mathrm{NH}_{4} \mathrm{Cl}$ & or fish & time of & fatality \\
\hline $14.2^{\circ} \mathrm{C}$ & $\ln$ & Pish in & $100 / t$ \\
\hline & grams & minutes & \\
\hline 0.0616 & 2.0 & $60^{?}$ & 1.66 \\
\hline${ }^{\prime \prime}$ & 2.6 & 101 & 0.99 \\
\hline 0.0787 & 2.0 & 58 & 1.72 \\
\hline$n$ & 2.0 & 58 & 1.72 \\
\hline 0.092 & 2.7 & 68 & 1.47 \\
\hline$\eta$ & 3.0 & 65 & 1.54 \\
\hline
\end{tabular}



TABLE $\mathrm{X}$ 。

The survival time and the relocity of fatality of the blunt-noscd minnow, Pimephale notatus Raf:, in ammon-Iuri chloride.

\begin{tabular}{|c|c|c|c|}
\hline Norma 1 & - Weight & Survival & Velocity of \\
\hline $\mathrm{NH}_{4} \mathrm{Cl}$ & of fish & time of & fatality \\
\hline \multirow[t]{2}{*}{$19.8^{\circ} \mathrm{C}$} & in & fish in & $100 / t$ \\
\hline & grams & minutes & \\
\hline \multirow{2}{*}{0.006} & 1.9 & $7000 \pm$ & 0.014 \\
\hline & 1.6 & $5100 \pm$ & 0.019 \\
\hline \multirow{2}{*}{0.0065} & - 2.0 & 249 & 0.40 \\
\hline & 2.0 & 281 & 0.36 \\
\hline \multirow{2}{*}{0.0071} & 2.0 & 247 & 0.40 \\
\hline & 2.0 & 340 & 0.29 \\
\hline \multirow{2}{*}{0.0076} & 1.4 & $4140 \pm$ & 0.024 \\
\hline & 1.6 & 6085 & 0.016 \\
\hline \multirow{2}{*}{0.0081} & - 1.9 & 397 & $0: 25$ \\
\hline & $2: 0$ & 498 & $0: 20$ \\
\hline \multirow{2}{*}{0.0086} & $1: 3$ & $3563 \pm$ & $0: 028$ \\
\hline & 2.2 & $3563 \pm$ & 0.028 \\
\hline \multirow{2}{*}{0.0091} & 2.0 & 189 & 0.39 \\
\hline & 2.1 & 278 & 0.52 \\
\hline \multirow{2}{*}{$0.00 \%$} & - 1.9 & 258 & 0.39 \\
\hline & 2.0 & 294 & 0.34 \\
\hline \multirow{2}{*}{$\begin{array}{l}0.0101 \\
0.0111\end{array}$} & 1.7 & 4782 & 0.02 \\
\hline & $1: 9$ & 447 & $0: 22$ \\
\hline \multirow{2}{*}{$n$} & 1.7 & 245 & 0.41 \\
\hline & 2.0 & 432 & 0.23 \\
\hline \multirow{2}{*}{0.0121} & 1.7 & 269 & 0.37 \\
\hline & 2.1 & $1140 \pm$ & 0.08 \\
\hline \multirow{2}{*}{0.0136} & 2.1 & $1140 \pm$ & 0.08 \\
\hline & 2.2 & $2730 \pm$ & 0.04 \\
\hline \multirow{2}{*}{0.0151} & 1.4 & 430 & 0.23 \\
\hline & 1.9 & 430 & 0.23 \\
\hline \multirow{2}{*}{0.0192} & - 1.9 & 270 & 0.37 \\
\hline & 2.0 & 137 & 0.73 \\
\hline \multirow{2}{*}{0.0242} & 1.6 & 203 & 0.49 \\
\hline & 1.7 & 336 & 0.30 \\
\hline \multirow{2}{*}{0.0303} & 1. 6 & 136 & $0: 74$ \\
\hline & 1.9 & 237 & 0.42 \\
\hline \multirow{2}{*}{0.0374} & 1.9 & 171 & 0.58 \\
\hline & 2.0 & 171 & $0: 58$ \\
\hline \multirow{2}{*}{0.0464} & 2.0 & 69 & 1.45 \\
\hline & $2: 0$ & 70 & 1.42 \\
\hline \multirow{2}{*}{0.0525} & 1.7 & 49 & 2.02 \\
\hline & 1.9 & 60 & 1.86 \\
\hline \multirow{2}{*}{0.0616} & 1.8 & 48 & 2.08 \\
\hline & 1.8 & 49 & 2.02 \\
\hline \multirow{2}{*}{0.0787} & 1.4 & 15 & 2.22 \\
\hline & 2.2 & 45 & 2.22 \\
\hline
\end{tabular}




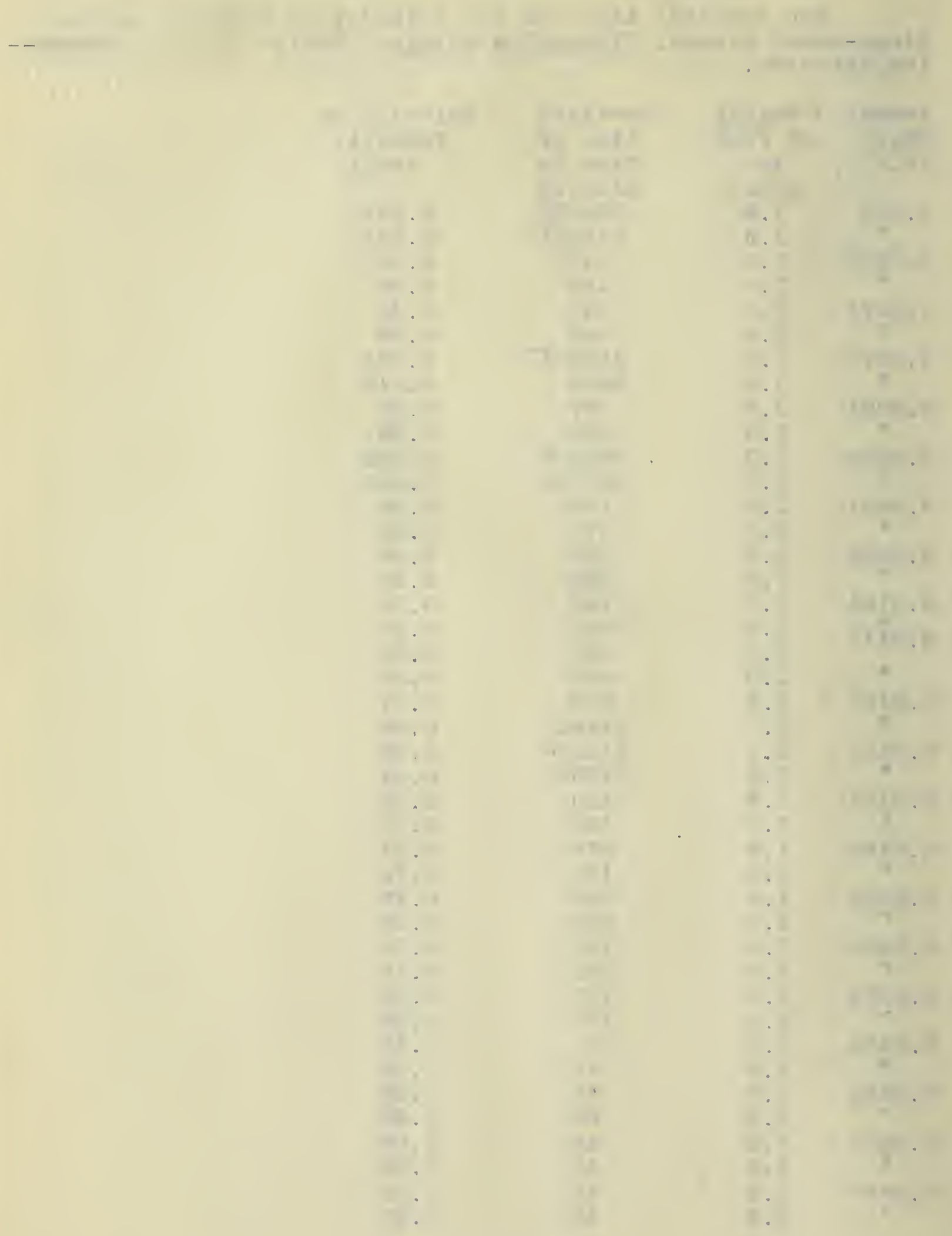


TABLE XI.

The survival time and the velocity of fatality of the blunt-nosed minnow, Pimephales notatus 'Raf;,.. ' in ammonfum chloride.

\begin{tabular}{|c|c|c|c|}
\hline Norma 1 & Weight & Survival & velocity of \\
\hline $\mathrm{NH}_{4} \mathrm{Cl}$ & of fish & time of & ratality \\
\hline $24.9^{\circ} \mathrm{C}$ & $\ln$ & fish in & $100 / t$ \\
\hline \multirow{2}{*}{0.006} & $\begin{array}{c}\text { grams } \\
2.0\end{array}$ & $\begin{array}{c}\text { minutes } \\
519\end{array}$ & 0.19 \\
\hline & 2.0 & $2709 \pm$ & 0.04 \\
\hline \multirow{2}{*}{0.0065} & 1.6 & $519 \neq$ & 0.19 \\
\hline & 2.8 & $2709 \pm$ & 0.04 \\
\hline \multirow{2}{*}{0.0071} & 2.4 & 1020 & 0.02 \\
\hline & 3.1 & 279 & 0.36 \\
\hline \multirow{2}{*}{0.0076} & 1.6 & 279 & 0.36 \\
\hline & 3.6 & 286 & 0.25 \\
\hline \multirow{2}{*}{0.0081} & 2.0 & 322 & 0.31 \\
\hline & 2.0 & 2768 & 0.04 \\
\hline \multirow{2}{*}{0.0086} & 1.8 & 1016 & 0.09 \\
\hline & & 1196 & 0.06 \\
\hline \multirow{2}{*}{0.0091} & 1.8 & 1607 & 0.06 \\
\hline & 2.2 & 2662 & 0.04 \\
\hline \multirow{2}{*}{0.0096} & 2.2 & 167 & 0.59 \\
\hline & 2.2 & 258 & 0.39 \\
\hline \multirow{2}{*}{0.0101} & 1.9 & 253 & 0.39 \\
\hline & 2.0 & 530 & 0.19 \\
\hline \multirow{2}{*}{0.0111} & 1.3 & 227 & 0.44 \\
\hline & 2.1 & 2660 & 0.04 \\
\hline \multirow{2}{*}{0.0121} & 1.5 & 269 & 0.37 \\
\hline & 2.1 & 59 & 1.69 \\
\hline \multirow{2}{*}{0.0137} & 2.3 & 185 & 0.58 \\
\hline & 2.3 & 239 & 0.42 \\
\hline \multirow{2}{*}{0.0151} & 1.7 & 143 & 0.70 \\
\hline & 3.2 & 139 & 0.72 \\
\hline \multirow{2}{*}{0.01771} & 2.0 & 174 & 0.57 \\
\hline & 2.2 & 400 & 0.25 \\
\hline \multirow{2}{*}{0.0192} & 1.8 & 169 & 0.58 \\
\hline & 2.9 & 110 & 0.91 \\
\hline \multirow{2}{*}{0.0242} & 1.5 & 131 & 0.76 \\
\hline & $2: 8$ & 116 & 0.85 \\
\hline \multirow{2}{*}{0.0303} & 1.9 & 62 & 1.61 \\
\hline & 2.0 & 86 & 1.16 \\
\hline \multirow{2}{*}{0.0374} & 1.7 & 47 & 2.12 \\
\hline & 1.8 & 47 & 2.12 \\
\hline \multirow{2}{*}{0.04 .64} & 1.8 & 46 & 2.17 \\
\hline & 1.8 & 59 & 1.69 \\
\hline \multirow{2}{*}{0.0525} & 1.8 & 30 & 3.33 \\
\hline & 1.8 & 47 & 2.12 \\
\hline \multirow{2}{*}{0.0616} & 1.6 & 26 & 3.85 \\
\hline & 1.9 & 28 & 3.57 \\
\hline \multirow{2}{*}{0.0787} & 1.7 & 26 & 3.86 \\
\hline & 1.7 & 29 & 3.45 \\
\hline
\end{tabular}




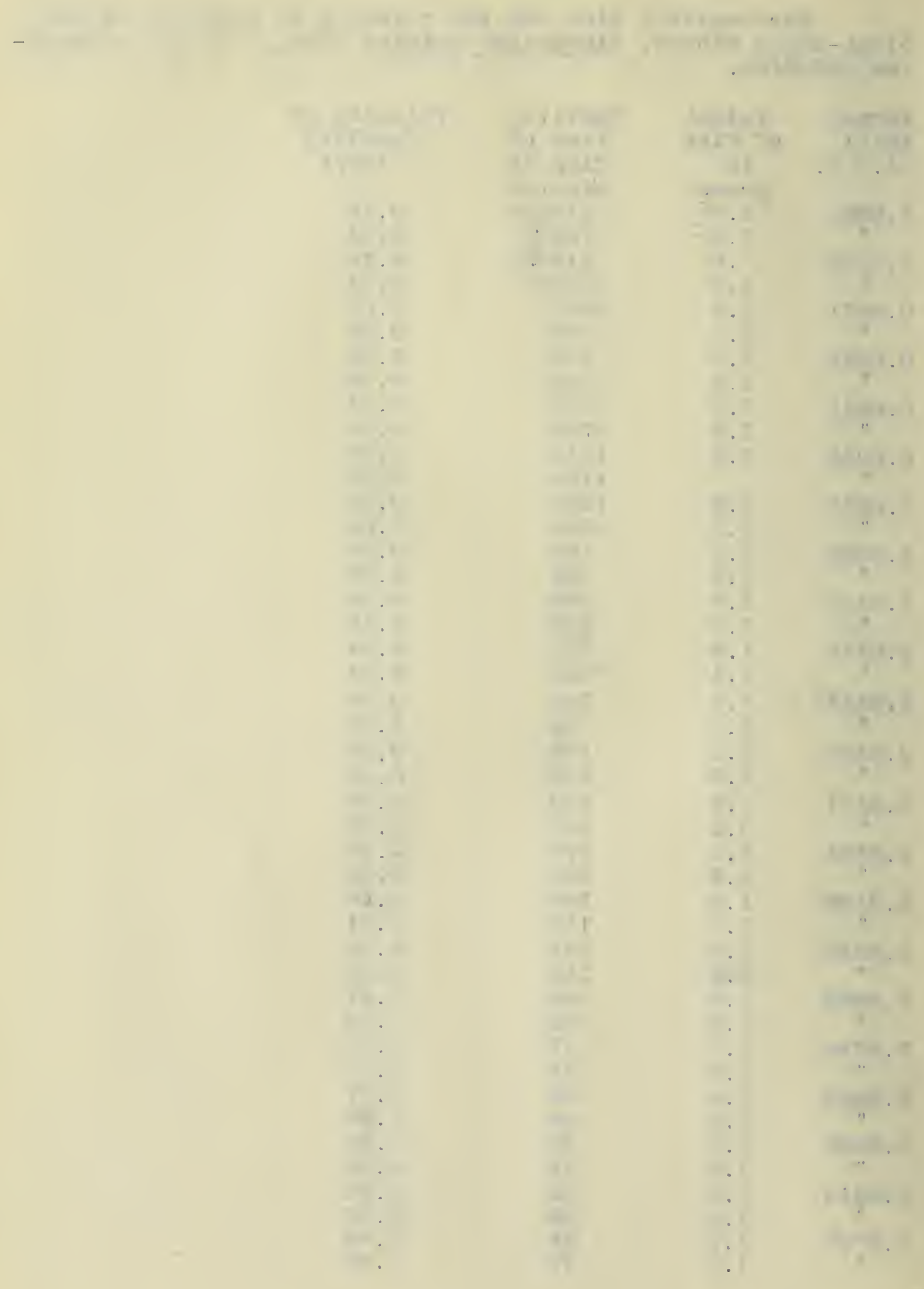


The survival time and the velocity of fatality of the stran-colored minnow, Notropis blennius Gir, in ammonium chloride. Column 5 gives relative conductance.

$\begin{array}{ccccc}\text { Normal } & \text { Welght } & \text { Survival } & \text { Velocity of } & \text { Relative } \\ \mathrm{NH}_{4} \mathrm{Cl} & \text { of fish } & \text { time of } & \text { fatily } & \text { conductance } \\ 15.5^{\circ} \mathrm{C} . & \text { In } & \text { fishin } & 100 / t & \\ \text { grams } & \text { minutes } & & \end{array}$

\begin{tabular}{|c|c|c|c|c|}
\hline 0.0084 & -- & 7200 & 0.01 & 0.03 \\
\hline 0.017 & 1.3 & $860 \pm$ & 0.12 & 0.07 \\
\hline$n$ & 1.3 & $860 \pm$ & 0.12 & \\
\hline$"$ & -- & 602 & 0.17 & m \\
\hline 0.034 & 1.2 & 190 & 0.53 & 0.15 \\
\hline & 1.4 & 241 & 0.41 & \\
\hline$"$ & $\ldots$ & 241 & 0.41 & * \\
\hline " &.- & 321 & 0.31 & $n$ \\
\hline 0.050 & 1.2 & 190 & 0.53 & 0.21 \\
\hline$"$ & 1.4 & 160 & 0.63 & \\
\hline 0.067 & 1.4 & 122 & 0.82 & 0.27 \\
\hline$"$ & 1.5 & $300 \pm$ & 0.33 & \\
\hline 0.073 & 0.8 & 75 & 1.33 & 0.30 \\
\hline n & 1.1 & 91 & $1: 10$ & \\
\hline 0.100 & 0.9 & 64 & 1.55 & 0.40 \\
\hline$"$ & 1.0 & 56 & 1.78 & \\
\hline$\pi$ & 1.2 & 57 & 1.75 & $"$ \\
\hline$n$ & 1.6 & 65 & 1.54 & $n$ \\
\hline 0.135 & 1.0 & 37 & 2.70 & 0.55 \\
\hline$n$ & 1.0 & 41 & 2.44 & \\
\hline$n$ & 1.1 & 37 & 2.70 & $n$ \\
\hline$n$ & 1.3 & 41 & 2.44 & $n$ \\
\hline 0.168 & 1.0 & 25 & 4.00 & 0.70 \\
\hline$n$ & 1.1 & 25 & 4.00 & . \\
\hline$n$ & 1.2 & 40 & 2.50 & $"$ \\
\hline$n$ & 1.3 & 40 & 2.50 & $n$ \\
\hline 0.202 & 1.5 & 40 & 2.50 & 0.77 \\
\hline n & 1.5 & 39 & 2.56 & \\
\hline 0.235 & 1.0 & 19 & 3.26 & 0.85 \\
\hline$n$ & 1.1 & 18 & 5.56 & \\
\hline 0.252 & 1.6 & 16 & 6.25 & 0.96 \\
\hline " & 2.2 & 18 & 5.56 & \\
\hline 0.269 & 1.0 & 18 & 5.56 & 1.07 \\
\hline oge & 1.2 & 18 & 5.56 & \\
\hline$n$ & 1.2 & 17 & 5.89 & $n$ \\
\hline " & 1.5 & 17 & 5.89 & $n$ \\
\hline 0.336 & 0.7 & 9 & 11.11 & 1.35 \\
\hline$n$ & 1.0 & 9 & 11.11 & \\
\hline " & 1.4 & 17 & 5.89 & 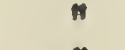 \\
\hline$"$ & 1.5 & 17 & 5.89 & \\
\hline 0.404 & 0.9 & 8 & 12.50 & $1 . \frac{45}{m}$ \\
\hline 0.470 & $1: 0$ & 8 & $72: 56$ & 1.82 \\
\hline " & 1.2 & 8 & 12.50 & \\
\hline
\end{tabular}




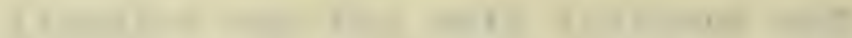

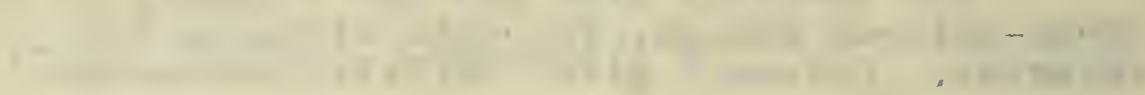

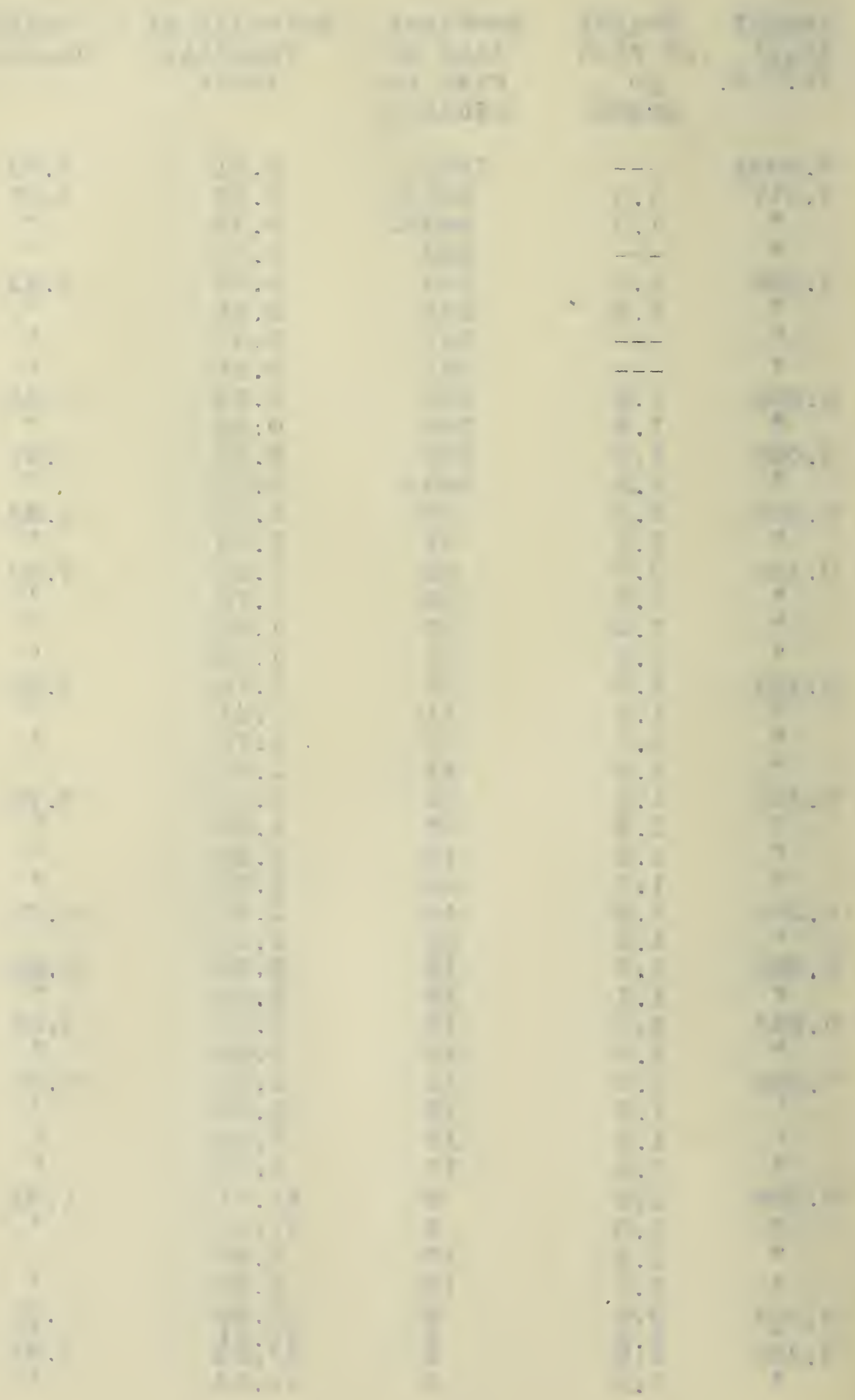


TABLE XIIT.

The surviral time and the relocity of fatality of the straw-colored minnow, Notropis blennius Gir, in ammonium chloride.

\begin{tabular}{|c|c|c|c|c|c|c|}
\hline $\begin{array}{l}\text { Nomal } \\
\mathrm{NH}_{4} \mathrm{Cl} \\
19.8^{\circ} \mathrm{C} \text {. }\end{array}$ & $\begin{array}{l}\text { Weight } \\
\text { of fish } \\
\text { in } \\
\text { grams }\end{array}$ & $\begin{array}{l}\text { Survival } \\
\text { time of } \\
\text { fish in } \\
\text { minutes }\end{array}$ & & $\begin{array}{l}\text { locity of } \\
\text { fatality } \\
100 / t\end{array}$ & & \\
\hline 0.001 & $\begin{array}{l}? \\
?\end{array}$ & Aldre arter & $\underset{H}{50500}$ & minutes. & $\underset{M}{\operatorname{Expt}}$ & discontinued. \\
\hline 0.0015 & $?$ & $\stackrel{+}{M}$ & " & " & $"$ & " \\
\hline 0.002 & 2.1 & 6120 & & 0.016 & & \\
\hline 0.003 & $2^{?} .8$ & $\begin{array}{c}\text { Alive after } \\
6420\end{array}$ & 50500 & minutes. & Expt. & discontinued. \\
\hline 0.003 & $\begin{array}{l}2.8 \\
2.8\end{array}$ & $\begin{array}{l}6420 \\
6420\end{array}$ & & $\begin{array}{l}0.015 \\
0.015\end{array}$ & & \\
\hline 0.004 & 3.4 & 6420 & & 0.015 & & \\
\hline 0 & ? & $30240 \pm$ & & 0.008 & & \\
\hline 0.005 & $?$ & 18720屯 & & 0.006 & & \\
\hline 0.0076 & ? & $18720 \pm$ & & 0.006 & & \\
\hline 0.0076 & 4.2 & $\begin{array}{r}6240 \\
28800\end{array}$ & & $\begin{array}{l}0.016 \\
0.003\end{array}$ & & \\
\hline 0.012 & 1.0 & 907 & & 0.113 & & \\
\hline " & 3.2 & 387 & & 0.26 & & \\
\hline 0.015 & 1.6 & 131 & & 0.76 & & \\
\hline & 1.6 & 216 & & $\begin{array}{l}0.46 \\
0.71\end{array}$ & & \\
\hline 0.019 & $\begin{array}{l}2.7 \\
3.1\end{array}$ & $\begin{array}{r}141 \\
96\end{array}$ & & $\begin{array}{l}0.71 \\
1.04\end{array}$ & & \\
\hline 0.024 & 0.7 & 431 & & 0.23 & & \\
\hline$n$ & 1.8 & 101 & & 0.99 & & \\
\hline 0.030 & 1.2 & 62 & & 1.61 & & \\
\hline & 1.1 & 56 & & 1.80 & & \\
\hline 0.037 & $\begin{array}{l}0.6 \\
1.2\end{array}$ & $\begin{array}{l}64 \\
52\end{array}$ & & $\begin{array}{l}1.56 \\
1.92\end{array}$ & & \\
\hline 0.046 & 0.8 & 123 & & 0.81 & & \\
\hline & 1.3 & 58 & & $\begin{array}{l}1.72 \\
1.26\end{array}$ & & \\
\hline $0.0 h^{3}$ & $\begin{array}{l}1.3 \\
1.8\end{array}$ & 48 & & 2.04 & & \\
\hline 0.062 & $1: 8$ & 42 & & $2: 38$ & & \\
\hline 0.079 & $\begin{array}{l}2.2 \\
1.8\end{array}$ & $\begin{array}{l}53 \\
47\end{array}$ & & 1.85 & & \\
\hline 0.0 & $\begin{array}{l}1.8 \\
3.3\end{array}$ & $\begin{array}{l}47 \\
33\end{array}$ & & $\begin{array}{l}2.38 \\
3.03\end{array}$ & & \\
\hline 0.101 & 1.3 & 25 & & 4.00 & & \\
\hline & 2.2 & 39 & & 2.57 & & \\
\hline 0.126 & 0.6 & 32 & & 3.13 & & \\
\hline$N$ & 1.3 & 32 & & 3.13 & & \\
\hline 0.161 & 1.2 & 20 & & 5.00 & & \\
\hline & 1.5 & 29 & & $\begin{array}{l}3.45 \\
5.56\end{array}$ & & \\
\hline 0.202 & $\begin{array}{l}1.3 \\
2.3\end{array}$ & $\begin{array}{l}18 \\
17\end{array}$ & & $\begin{array}{l}5.56 \\
5.88\end{array}$ & & \\
\hline 0.252 & $3: 9$ & $\begin{array}{l}76 \\
20\end{array}$ & & $\begin{array}{l}6: 25 \\
5.00\end{array}$ & & \\
\hline 0.303 & 0.9 & 11 & & 9.09 & & \\
\hline & 2.6 & 12 & & 8.66 & & \\
\hline 0.353 & 1.1 & $\begin{array}{l}8 \\
8\end{array}$ & & 12.50 & & \\
\hline & 1.1 & 8 & & 12.50 & & \\
\hline
\end{tabular}




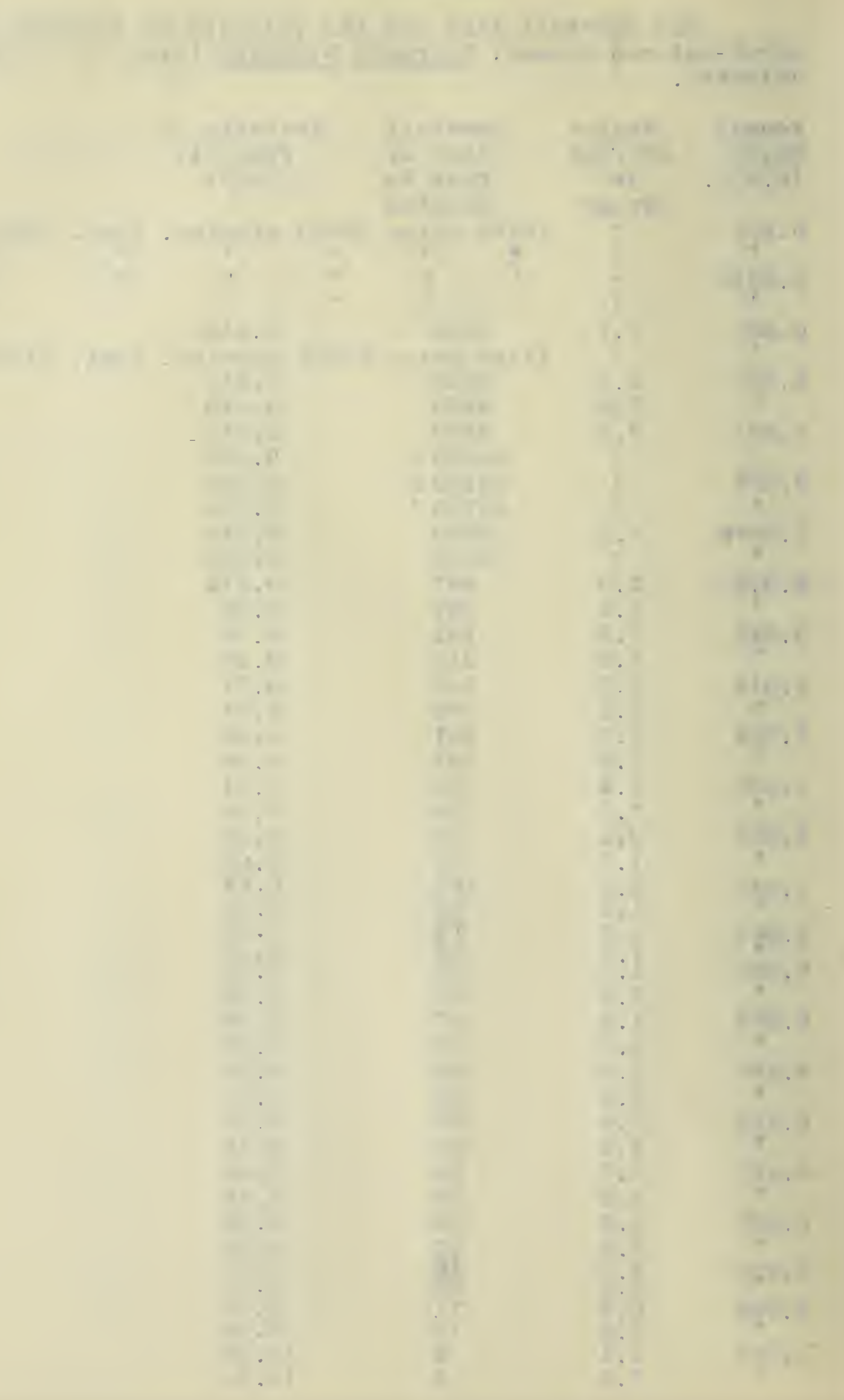


TABLE XIII Continued.

\begin{tabular}{|c|c|c|c|}
\hline Normal & Welght & Survival & Velocity of \\
\hline $\mathrm{NH}_{4} \mathrm{Cl}$ & of fish & time of & fatality \\
\hline $19^{4} \cdot 8^{\circ} \mathrm{C}$ & $\underset{\text { grams }}{\operatorname{In}}$ & $\begin{array}{l}\text { f1sh in } \\
\text { minutes }\end{array}$ & $100 / t$ \\
\hline 0,404 & 0.9 & 7 & $14: 28$ \\
\hline & 2.3 & 7 & 14.28 \\
\hline 0.505 & 0.9 & 3 & 33.33 \\
\hline & 1.5 & 5 & 20.00 \\
\hline 0.555 & 0.7 & 2 & 50.00 \\
\hline & 2.2 & 3 & 33.33 \\
\hline 0.606 & 1.1 & 2 & 50.00 \\
\hline & 1.1 & 2 & 00 \\
\hline
\end{tabular}



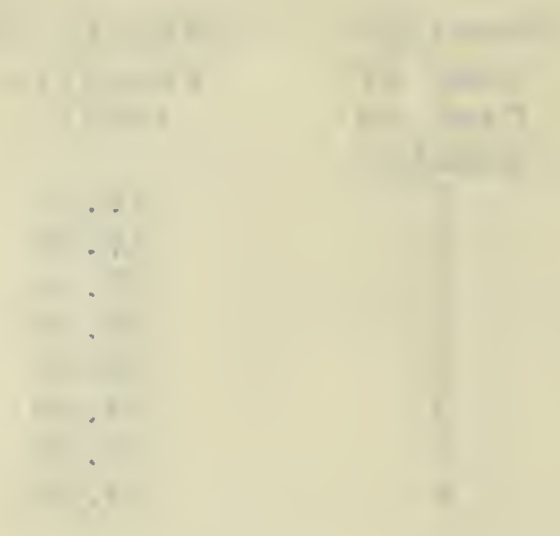

+1

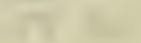

$+2$
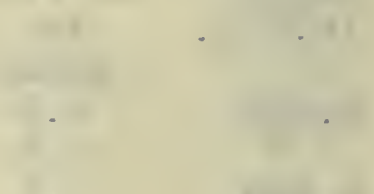

?

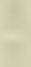

(x

71

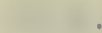




\section{TABLE XIV.}

The $Q_{10}$ of toxicity, of lithium chloride to goldfish. The calculations are based upon the temperature toxicity curve of lithlum chloride to goldfish. Figure 12.

$\begin{array}{cc}\text { Temperatures } & \text { The } Q_{1} \\ \text { Centigrade. } & \\ 4^{\circ} \text { to } 14^{\circ} & 1.39 \\ 6^{\circ} \text { to } 16^{\circ} & 1.47 \\ 8^{\circ} \text { to } 18^{\circ} & 1.53 \\ 10^{\circ} \text { to } 20^{\circ} & 1.59 \\ 12^{\circ} \text { to } 22^{\circ} & 1.64 \\ 14^{\circ} \text { to } 24^{\circ} & 1.66 \\ 16^{\circ} \text { to } 26^{\circ} & 1.67 \\ 18^{\circ} \text { to } 28^{\circ} & 1.70 \\ 20^{\circ} \text { to } 30^{\circ} & 1.75 \\ 22^{\circ} \text { to } 32^{\circ} & 1.90 \\ 24^{\circ} \text { to } 34^{\circ} & 2.23\end{array}$





\section{TABLE XV .}

Table showing the ratio of the square rout of the temperature standard metabolism curve of vertebrates as given by Krogh (1914c) to the temperature toxicity curve of lithilim chlorlde of the goldfish.

Temperature Ratio

centigrade

$\begin{array}{rr}4^{\circ} & 1.89 \\ 6^{\circ} & 1.89 \\ 8^{\circ} & 1.72 \\ 10^{\circ} & 1.66 \\ 12^{\circ} & 1.56 \\ 14^{\circ} & 1.55 \\ 16^{\circ} & 1.55 \\ 18^{\circ} & 1.55 \\ 20^{\circ} & 1.58 \\ 22^{\circ} & 1.63 \\ 24^{\circ} & 1.64 \\ 26^{\circ} & 1.71 \\ 28^{\circ} & 1.71\end{array}$



Temperature coefficient of the duration of life of Imagoes Males and females fed on "glucose-agar".

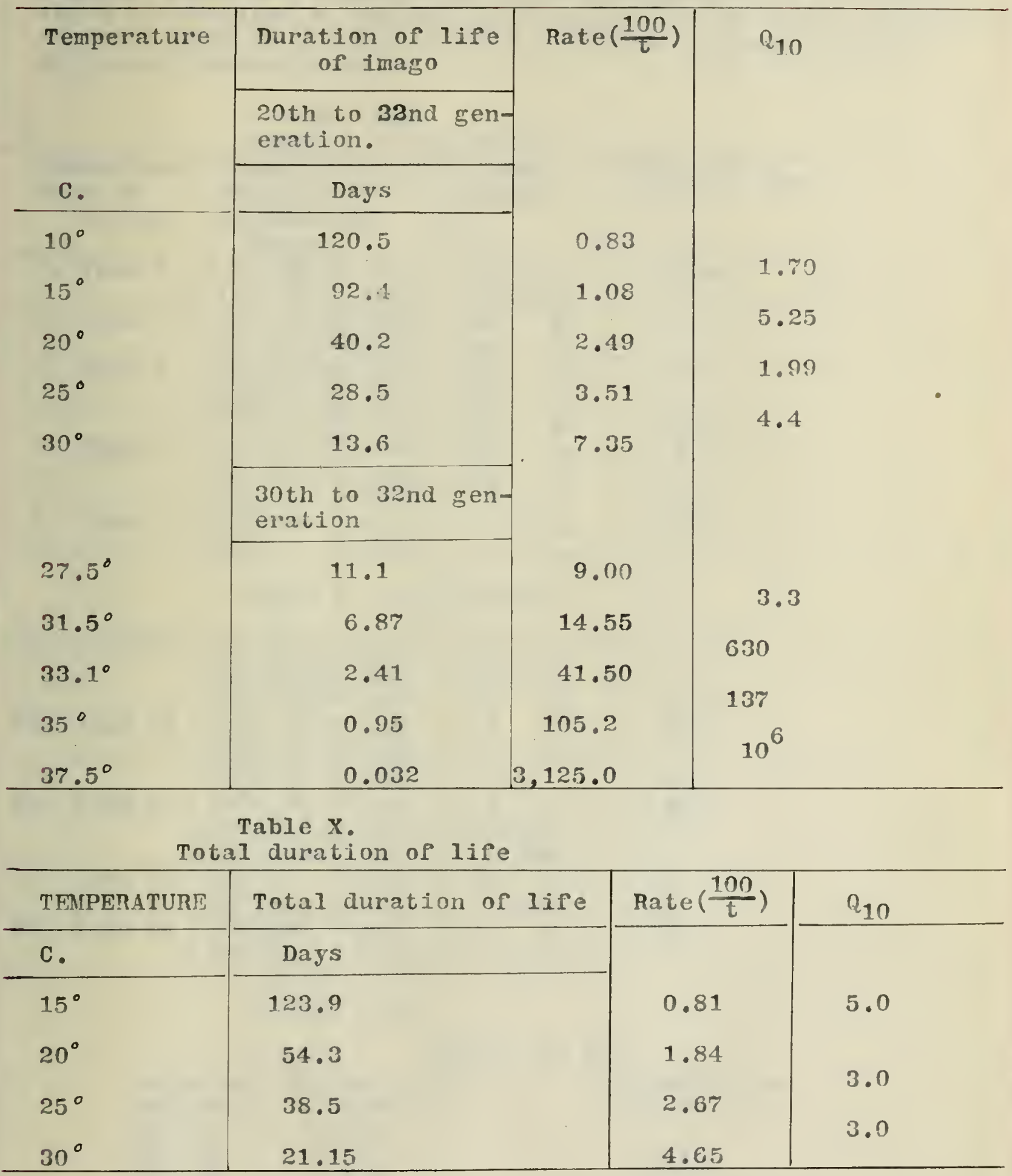



This table is made up of tro tables taken from Jillie $(1917)$. The two tables rere formulated by Lillie from data which he obtained by determining the time of exposure required by starrish eggs to $0.006 \mathrm{~N}$. hutyric acid to activale them at different temperatures.

Table II.

Group A. (June 9-12).

\begin{tabular}{|c|c|c|c|}
\hline $\begin{array}{l}\text { Number and } \\
\text { date of } \\
\text { series }\end{array}$ & $\begin{array}{l}\text { Temperature of } \\
\text { solution and } \\
\text { optimum ex- } \\
\text { nosure }\end{array}$ & $\begin{array}{c}\text { Mean } \\
\text { optimum }\end{array}$ & Value of $Q_{10}$ \\
\hline 2. June 9 & $\begin{array}{r}8^{\circ}: 35-40 \text { min. } \\
18^{\circ}: 9-12 \text { min. }\end{array}$ & $\begin{array}{l}37.5 \mathrm{~m} . \\
10.5 \mathrm{~m} .\end{array}$ & 3.55 \\
\hline 6. June 1.2 & $\begin{array}{r}8^{\circ}: 36-40 \text { min. } \\
10^{\circ}: 32-36 \text { min. }\end{array}$ & $\begin{array}{ll}38 & \text { in. } \\
31 & \mathrm{~m} .\end{array}$ & 1.75 \\
\hline 3. June 9 & $\begin{array}{l}10^{\circ}: 26-30 \text { min. } \\
12^{\circ}: 22-20 \text { min. }\end{array}$ & $\begin{array}{ll}28 & \text { m. } \\
24 & \text { m. }\end{array}$ & 2.2 \\
\hline 4. June 10 & $\begin{array}{l}14^{\circ}: 22-2, \min \\
16^{\circ}: 18-20 \text { min. } \\
18^{\circ}: \text { ca. } 14 \text { min. }\end{array}$ & $\begin{array}{ll}23 & \text { m. } \\
19 & \mathrm{~m} . \\
14 & \text { m. }\end{array}$ & $\begin{array}{l}2.6 \\
4.65\end{array}$ \\
\hline 7. June 12 & $\begin{array}{l}20^{\circ}: \quad 9 \min . \\
22^{\circ}: 6-7 \min . \\
24^{\circ}: \quad 4 \min .\end{array}$ & $\begin{array}{ll}9 & \mathrm{~m} . \\
6.5 \mathrm{~m} . \\
4 & \mathrm{~m} .\end{array}$ & $\begin{array}{r}5.0 \\
11.6\end{array}$ \\
\hline
\end{tabular}

Group B. (June 22-26).

\begin{tabular}{|c|c|c|c|}
\hline 23. June 26 & $\begin{aligned} 8^{\circ}: 21-21 & \min \\
10^{\circ}: 18-21 & \min \end{aligned}$ & $\begin{array}{l}22.5 \mathrm{~m} . \\
19.5 \mathrm{~m} .\end{array}$ & 2.0 \\
\hline 22. June 26 & $\begin{array}{l}12^{\circ}: 8-14 \text { min. } \\
14^{\circ}: 8-10 \text { min. } \\
16^{\circ}: 6-8 \text { min. }\end{array}$ & $\begin{array}{rl}11 & \mathrm{~m} \\
9 & \mathrm{~m} . \\
7 & \mathrm{~m} .\end{array}$ & $\begin{array}{l}2.7 \\
3.55\end{array}$ \\
\hline 21. June 24 & $\begin{array}{l}18^{\circ}: 5-6 \mathrm{~min} . \\
20^{\circ}: 3-5 \mathrm{~min} . \\
22^{\circ}: 2.5-3 \mathrm{~min} . \\
24^{\circ}: 1.5-2 \mathrm{~min} .\end{array}$ & $\begin{array}{l}5.5 \\
4.75 \mathrm{~m} . \\
2.75 \mathrm{~m} . \\
1.75 \mathrm{~m} .\end{array}$ & $\begin{array}{l}5.0 \\
6.4 \\
9.5\end{array}$ \\
\hline 17. June 22 & $\begin{array}{l}24^{\circ}: \quad 2 \text { min. } \\
26^{\circ}: 1-1.5 \text { min. }\end{array}$ & $\begin{array}{l}2 \quad \mathrm{~m} . \\
1.25 \mathrm{~m} .\end{array}$ & 10.5 \\
\hline 20. June 24 & $\begin{array}{l}26^{\circ}: \mathrm{cs} .1 \mathrm{~min} . \\
28^{\circ}: \mathrm{ca} . .5 \mathrm{~min} .\end{array}$ & $\begin{array}{r}1 \mathrm{~m} \\
.5 \mathrm{~m}\end{array}$ & 32.0 \\
\hline
\end{tabular}

Table III.

\begin{tabular}{ccc} 
& \multicolumn{2}{c}{ Values of $Q_{10}$} \\
Interval & A. June $9-12$. & B. June $22-26$. \\
$8^{\circ}-10^{\circ}$ & 1.75 & 2.0 \\
$10^{\circ}-12^{\circ}$ & 2.2 & 2.7 \\
$12^{\circ}-14^{\circ}$ & & 3.55 \\
$14^{\circ}-16^{\circ}$ & 2.6 & \\
$16^{\circ}-18^{\circ}$ & 4.65 & 5.0 \\
$18^{\circ}-20^{\circ}$ & & 6.4 \\
$20^{\circ}=22^{\circ}$ & 5.0 & 9.5 \\
$22^{\circ}-24^{\circ}$ & 11.6 & 10.5 \\
$24^{\circ}-20^{\circ}$ & & 32.0 \\
$26^{\circ}-28^{\circ}$ & &
\end{tabular}



TABLE XVIII.

The survival time and the velocity of fatality of the blunt-nosed minnow, Pimephales notatus Raf., rhen killed in $0.297 \mathrm{~N}$. calcium chloride to which different anounts of sodium chloride havebeen adred. Column one shows the normalty of the sodlum chloride in the $0.29 \%$, calcium chloride solution.

\begin{tabular}{|c|c|c|c|}
\hline Nomalitj & Weight & Survital & Velocity of \\
\hline of $\mathrm{NaCl}$ & of risil & time of & fatality \\
\hline $20^{\circ} \mathrm{C}$ & In & fish in & $100 / t$ \\
\hline & grams & minutes & \\
\hline 0.00 & 1.2 & 35 & 2.86 \\
\hline$n$ & 1.6 & 61 & 1.64 \\
\hline$n$ & 1.8 & 61 & 1.64 \\
\hline$"$ & 2.3 & 61 & 1.64 \\
\hline 0.00036 & $2 \cdot 0$ & 53 & 1.88 \\
\hline " & 2.1 & 53 & 1.88 \\
\hline 0.00074 & 1.7 & 62 & 1.61 \\
\hline & 1.7 & 68 & 1.47 \\
\hline 0.00148 & 1.8 & 34 & 2.94 \\
\hline & 3.1 & 31 & 3.22 \\
\hline 0.00297 & 1.4 & 70 & 1.42 \\
\hline " & 1.5 & 50 & 2.00 \\
\hline 0.00594 & 1.6 & 65 & 1.54 \\
\hline " & 2.0 & 52 & 1.92 \\
\hline 0.0119 & 1.8 & 73 & 1.37 \\
\hline$n$ & 1.9 & 38 & 2.63 \\
\hline 0.02376 & 1.5 & 99 & 1.01 \\
\hline$n$ & 2.0 & 54 & $1: 85$ \\
\hline 0.0445 & 1.7 & 34 & 2.95 \\
\hline$n$ & 2.5 & 29 & 3.45 \\
\hline 0.0817 & 1.4 & 47 & 2.13 \\
\hline$n$ & 1.6 & 39 & 2.56 \\
\hline 0.119 & 1.5 & 51 & 1.96 \\
\hline$"$ & $1 ; 6$ & 28 & 3.57 \\
\hline 0.156 & 1.3 & 26 & 3.85 \\
\hline " & 1.6 & 46 & 2.17 \\
\hline 0.230 & 1.6 & 31 & 3.22 \\
\hline & 2.2 & 38 & 2.63 \\
\hline
\end{tabular}



TABLE XIX.

The surrival time and the velocity of fatality of the blunt-nosed minnor, Pimephales notatus Raf., when killed in $0.297 \mathrm{~N}$. sodium chloride to which different anounts of calcium chloride have been added. Column one shows the norm wality of the calcium chloride in the $0.297 \mathrm{~N}$. sodium chloride solution.

\begin{tabular}{|c|c|c|c|}
\hline $\begin{array}{l}\text { Normality } \\
\text { of } \mathrm{CaCl}_{2} \\
20^{\circ} \mathrm{C} .\end{array}$ & $\begin{array}{l}\text { Weight } \\
\text { of fish } \\
\text { in }\end{array}$ & $\begin{array}{l}\text { Survival } \\
\text { tiune of } \\
\text { fish in }\end{array}$ & $\begin{array}{c}\text { Velocity of } \\
\text { fatality } \\
100 / t\end{array}$ \\
\hline & grams & minutes & \\
\hline 0.000 & 1.5 & 50 & 2.00 \\
\hline$" n$ & 1.5 & 67 & 1.49 \\
\hline$n$ & 1.7 & 41 & 2.44 \\
\hline$n$ & 1.8 & 59 & 1.69 \\
\hline$"$ & 2.2 & 65 & 1.54 \\
\hline$"$ & 2.9 & 48 & 2.08 \\
\hline 0.00036 & 2.0 & 64 & 1.56 \\
\hline & 2.2 & 64 & 1.56 \\
\hline 0.00074 & 1.7 & 84 & 1.19 \\
\hline$n$ & 1.8 & 55 & 1.82 \\
\hline 0.00148 & 1.3 & 44 & 2.22 \\
\hline$n$ & 1.7 & 66 & 1.51 \\
\hline 0.00297 & 1.6 & 57 & 1.75 \\
\hline$n$ & 1.6 & 60 & 1.66 \\
\hline 0.00594 & 1.7 & 66 & 1.51 \\
\hline$n$ & 1.8 & 78 & 1.28 \\
\hline 0.0119 & 1.5 & 85 & 1.17 \\
\hline$n$ & 1.8 & 78 & 1.28 \\
\hline 0.0237 & 1.6 & 82 & 1.22 \\
\hline " & 2.3 & 111 & 0.90 \\
\hline 0.0445 & 1.6 & 75 & 1.33 \\
\hline$n$ & 1.7 & 73 & 1.37 \\
\hline 0.0817 & 1.6 & 54 & 1.85 \\
\hline " & 1.7 & 68 & 1.46 \\
\hline 0.119 & 1.6 & 59 & 1.69 \\
\hline$"$ & 1.7 & 75 & 1.45 \\
\hline 0.156 & 2.0 & 46 & 2.17 \\
\hline & 2.0 & 55 & 1.82 \\
\hline 0.193 & 1.6 & 33 & 3.03 \\
\hline & 2.2 & 33 & 3.03 \\
\hline 0.230 & 1.7 & 29 & 3.45 \\
\hline$n$ & 2.2 & 22 & 4.55 \\
\hline 0.267 & 1.4 & 20 & 5.00 \\
\hline$n$ & 1.4 & 21 & 4.76 \\
\hline 0.297 & 1.7 & 23 & 4.35 \\
\hline$n$ & 1.7 & 20 & 5.00 \\
\hline$"$ & 1.7 & 21 & 4.76 \\
\hline " & 1.8 & 20 & 5.00 \\
\hline
\end{tabular}





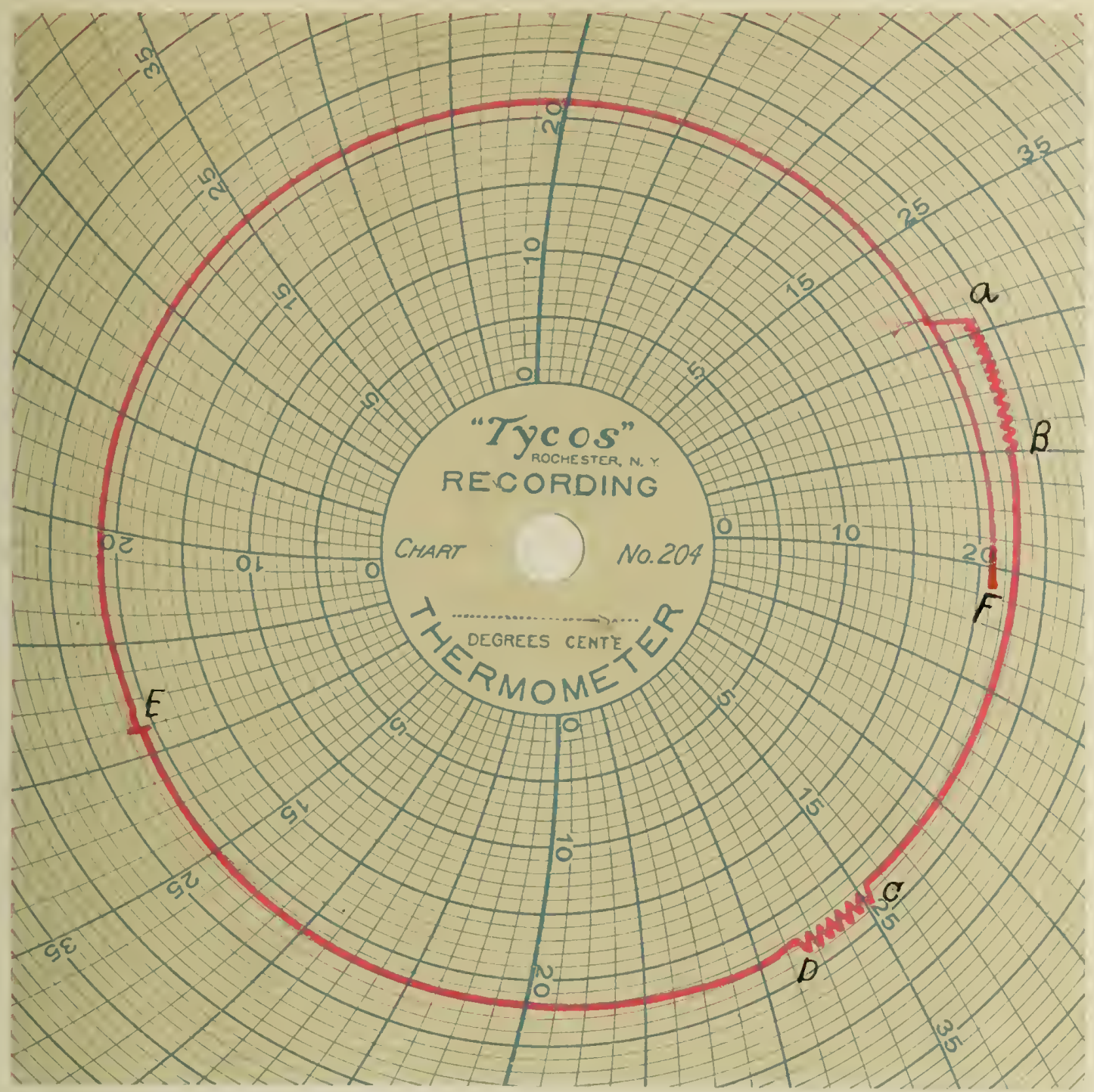

Figure 1. A Tycos recording thermometer record of the constant temperature bath showing the rariation in tcmperature, 1 to $B$ and $C$ to $D$, when the inflow or hot and cold water is large and the sight pariation in temperature when the hot and cold water is very small, E to F. The disk malics one complete revolution every trenty four hours. 

Figure 2. Graph showing the velocity of fatality curve, CABG, and the theoretical velocity of fatality curve, PABF, of the bluntnosed minnow (Pimephales notatus Raf.) when killed in anmonium chloride. LIJM is the surviral time curve and HIJK is the theoretical surviral time curve. Ordinate represents surviral time in minutes at left of figure and velocity of fatality at riglt of figure. Abscissa represcnts concentration of ammonium chilnidu. One blcck $=0.008 \%$. The plus signs $(t)$ represent survival time of individual fish and the circles $(\cdot)$ represent the velocity of fatality. 



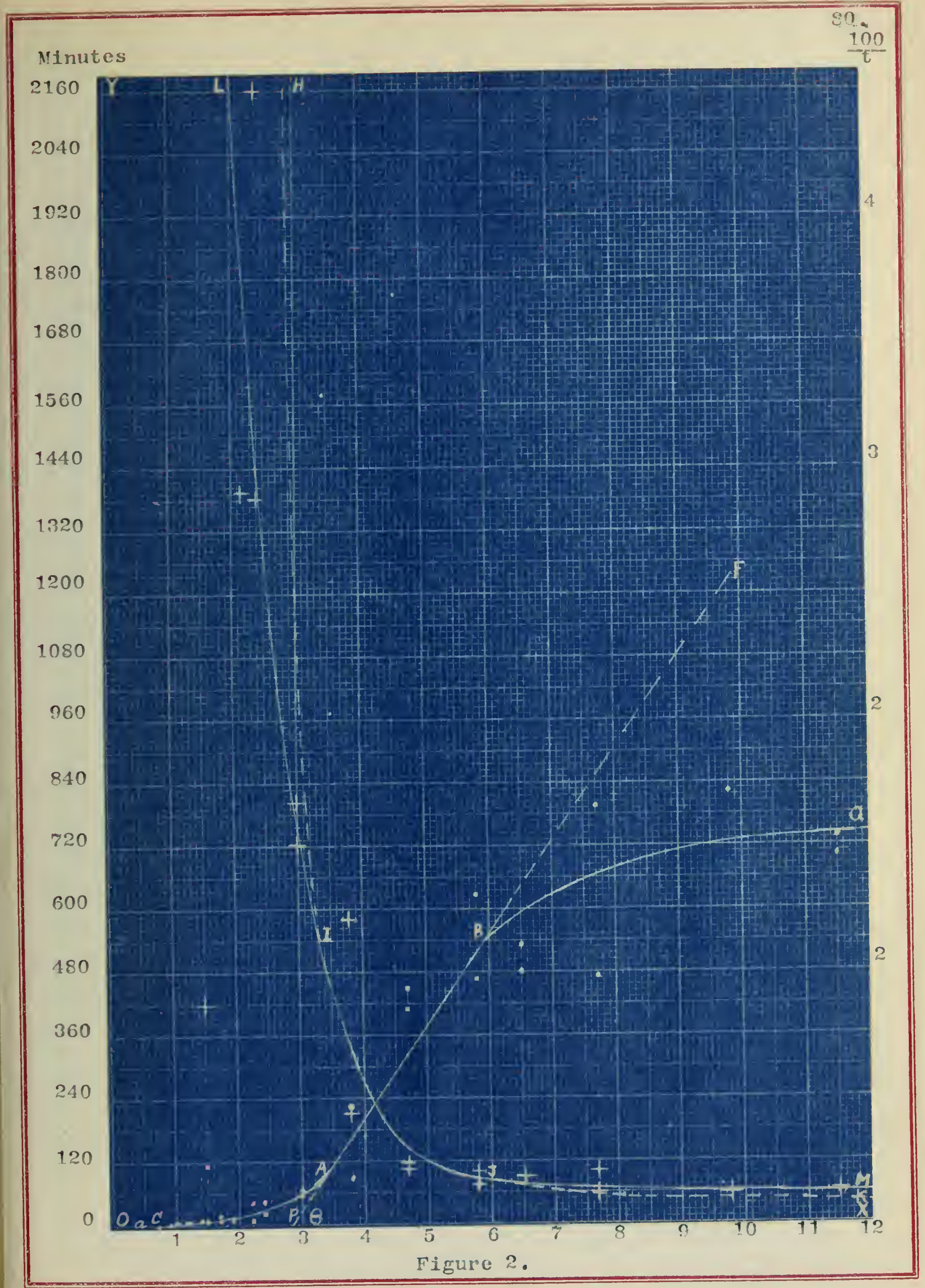



Flgure 3. Graph showing the velocity of falality curve of the straw-colored minnow, Notronis hlemnius Gir., when killed. in a very large range of concentrations of asmoniun chloride. One block ordinate represents four units of velocity of fatality and one block abscissa represenis $0.03 \mathrm{~N}$ a ammium chloride. 



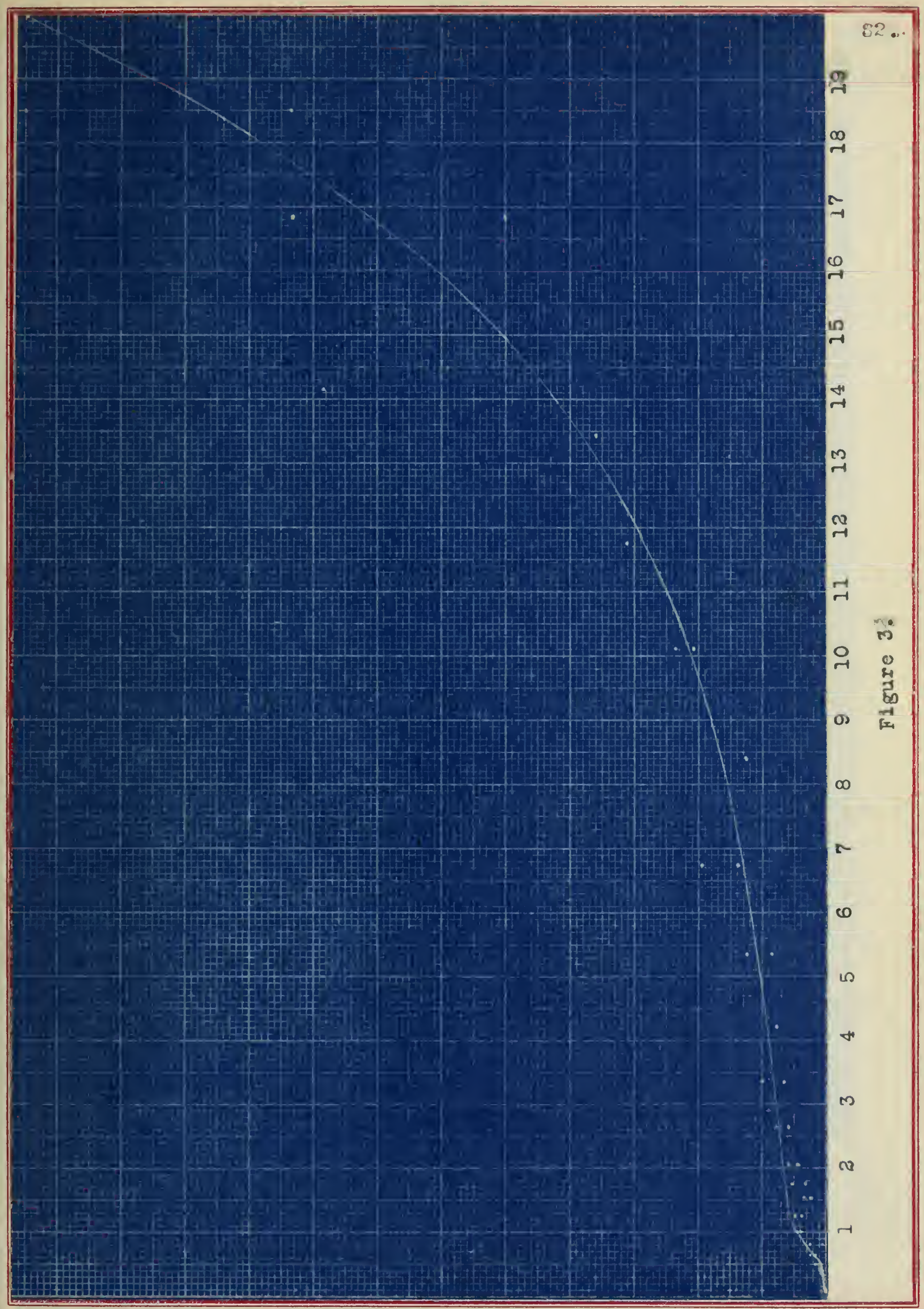





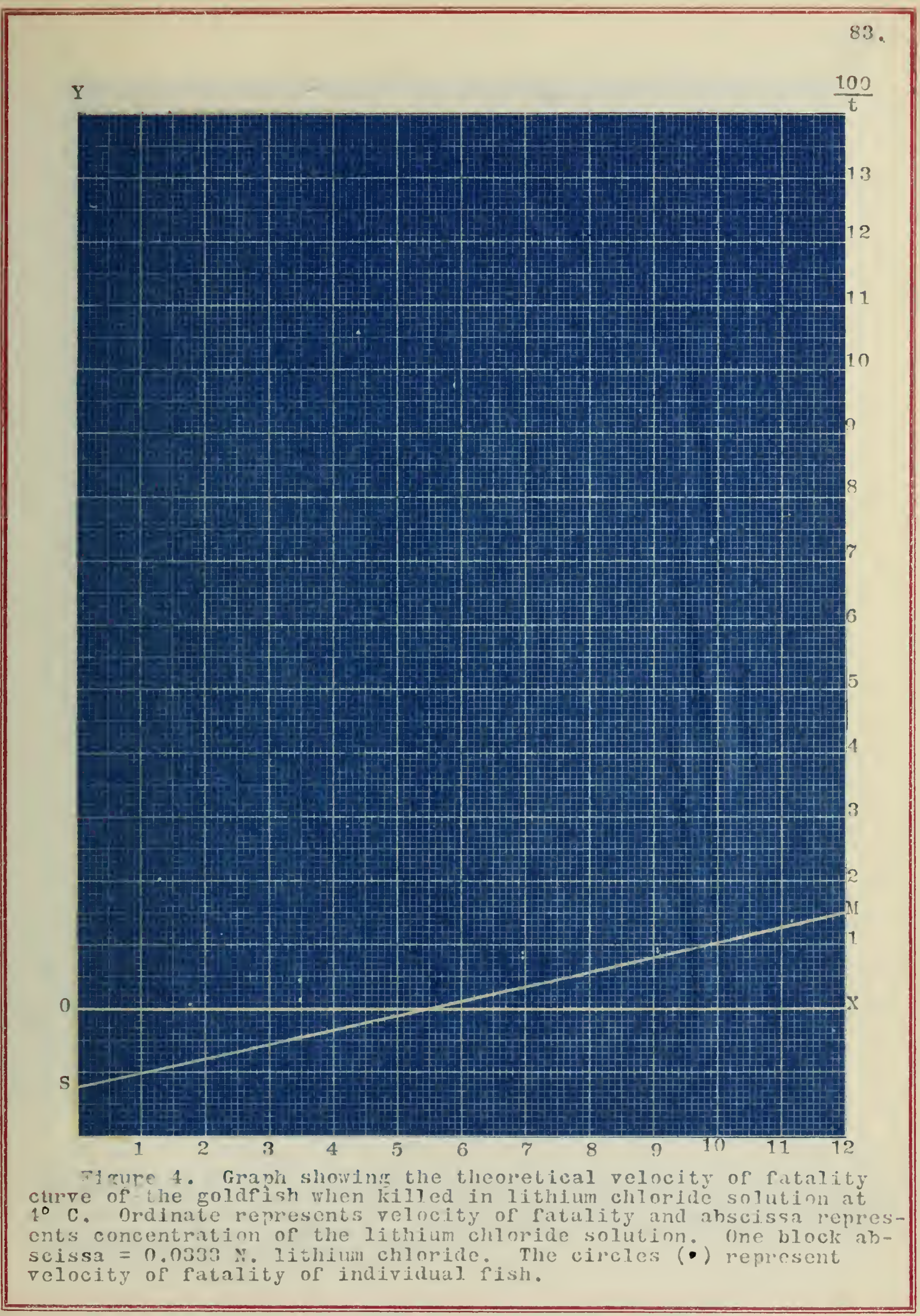




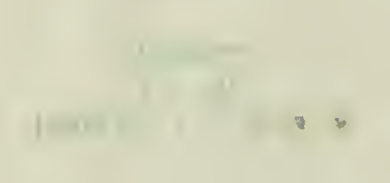




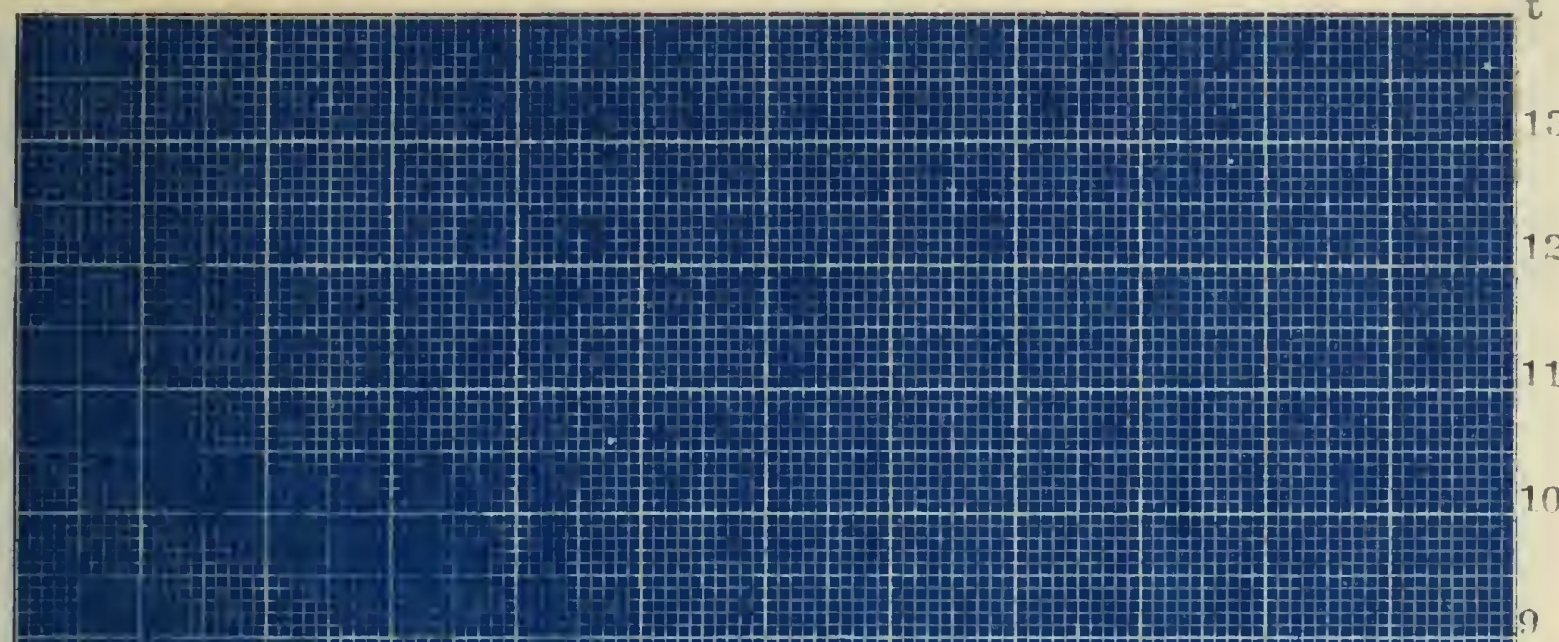

0

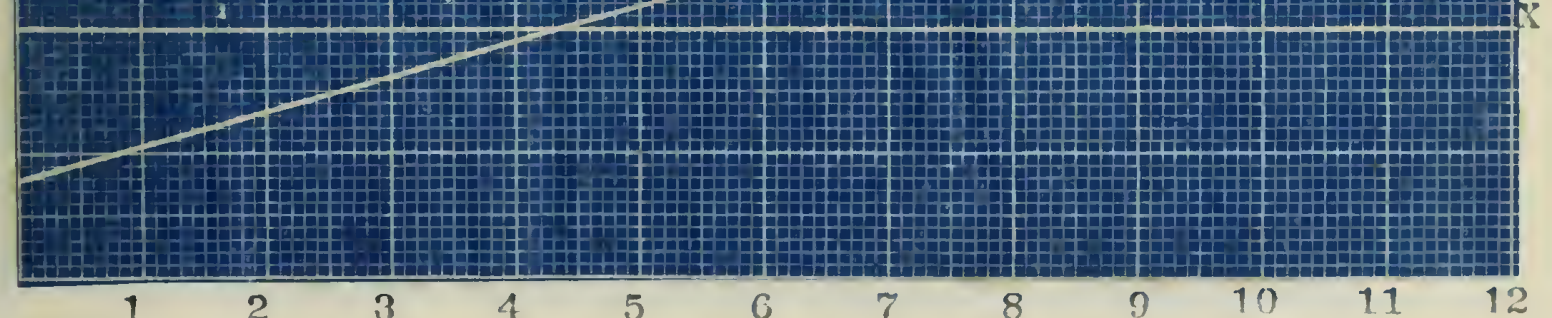

Figure 5. Graph showing the thenretical velncity or ratality curve of the goldfisls when killed in lithium chloride solution at $11.8^{\circ} \mathrm{C}$. Ordintle representis $\nabla$ socity of fatality and ahscissa represcnts concentration of the lithium chloridc. One block abscissa $=0.0333 \mathrm{~N}$. Ifthium chlnrike. The circles $(\bullet$ ) reprosent velocity of ratality of individual fish. 



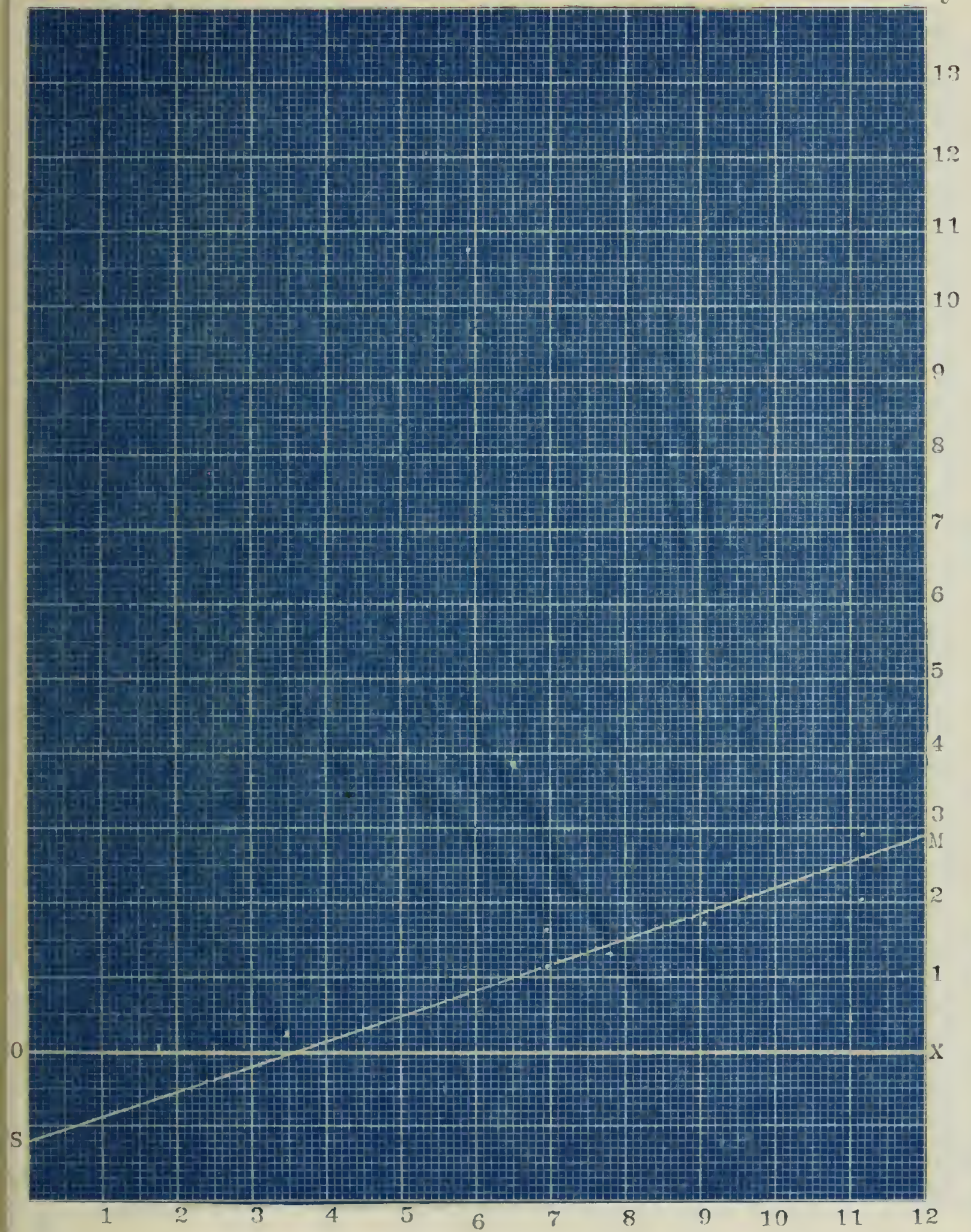

Figure 6 . Graph showing the theorctical velocity or ratality curve of the gnldfish when killed in lithium shlolide solution at represents concentration of lithium chloride solution. ent velocity of ratality or individual fish. 


$$
-7 .
$$


0

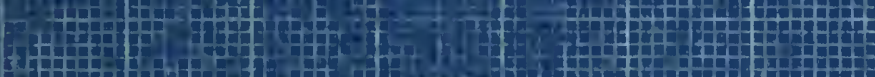

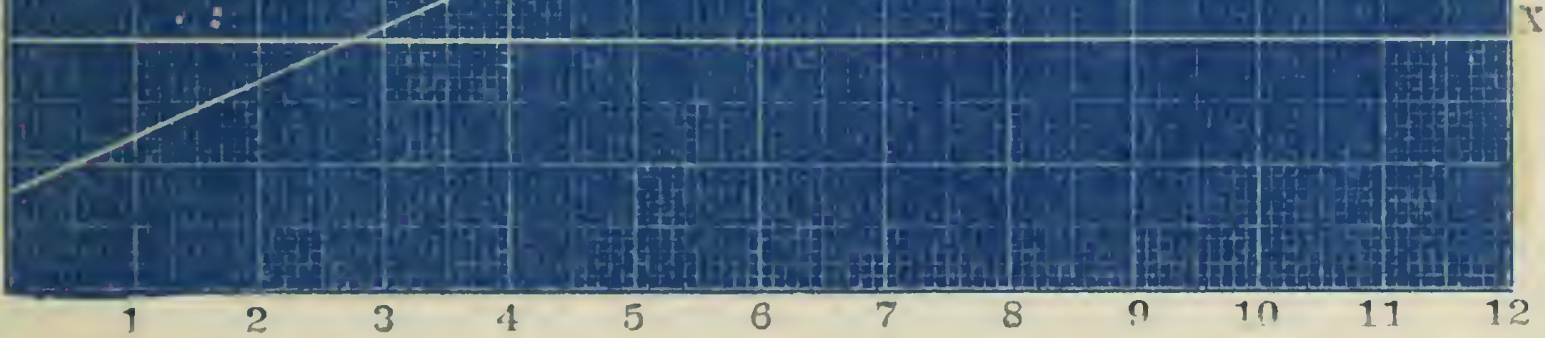

Figure 7. Graph showing the theorelical velocity of falality curre of the goldfish when killed in lithium chloride solution at $20^{\circ} \mathrm{C}$. 0rdinate ruresents vclocit" of fatality and abscissa represents concentrition of the litbium chloride snlution. One block abscissa $=0.0333 \mathrm{~N}$. Iithium chloride. The Circles resent velocity of fatality of individual fish. 

0

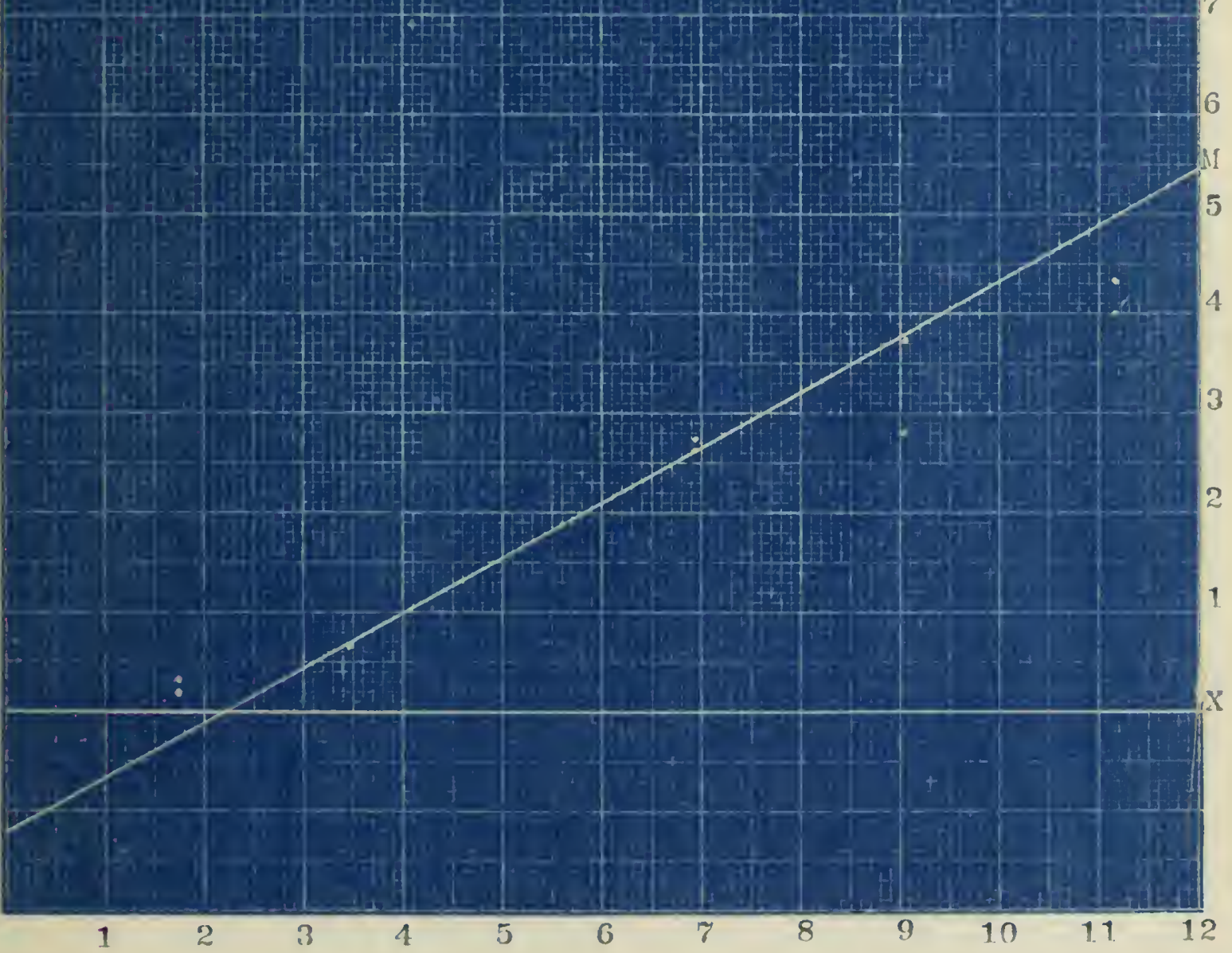

Figure 8. Graph slowing the tbeoretical velocity nf fatality curve of the goldfish when killed in a lithium chloride solution at $24.9^{\circ} \mathrm{C}$. Ordinate represents velncity of fatality and absissa represents concentration of the lithium chlorile solutinn. One block ahsciss $=0.7333 \mathrm{~N}$. Iithiun cliloride. The eircles (•) represent velocit of fatality of individual fish. 

0

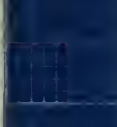

S

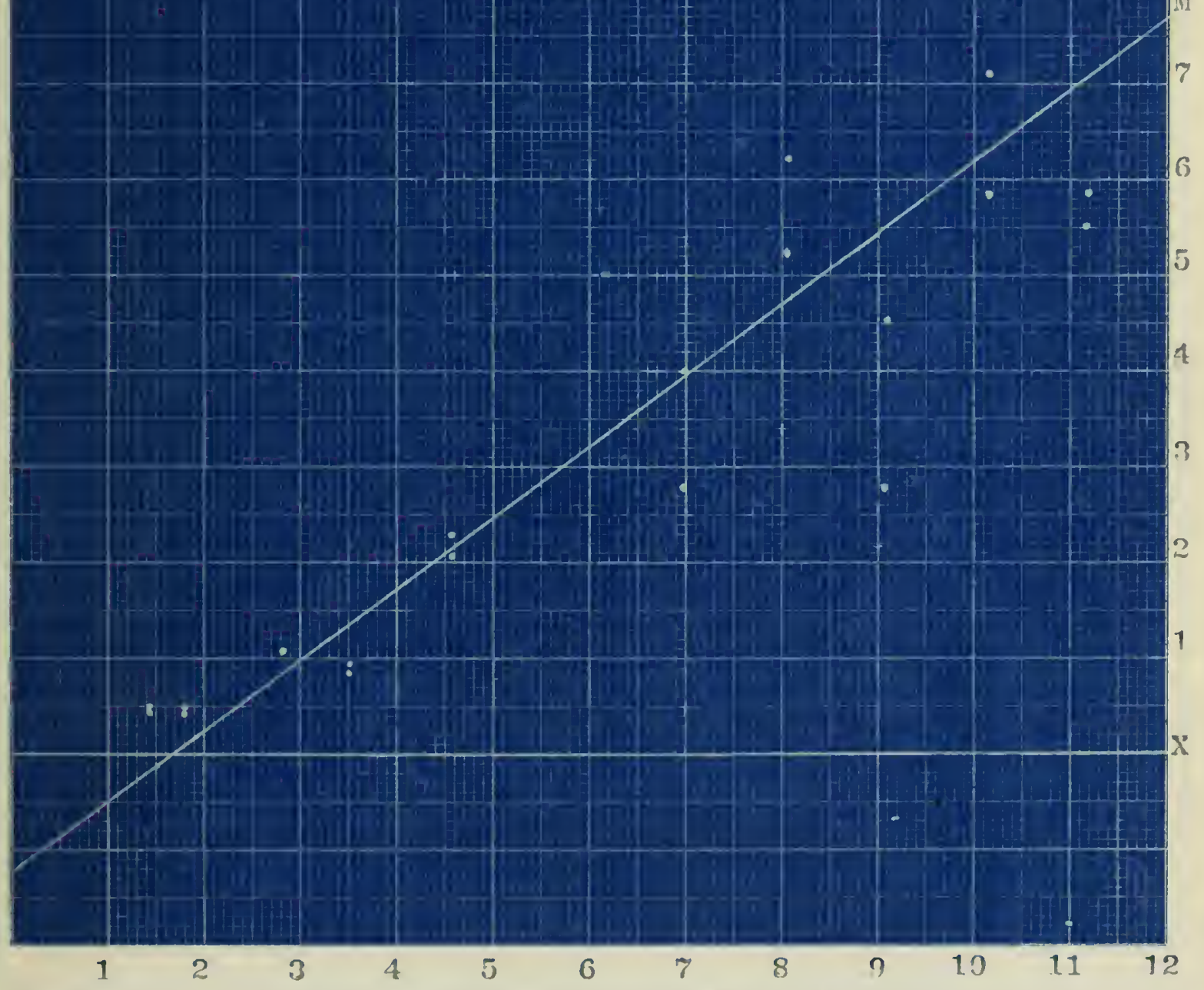

Figure 9. Graph slsowing the theorctical velocity of ratality curve of the goldfish when killed in lithium chloride solution at $29.8^{\circ} \mathrm{C}$. Ordinate represcnts velocity of fatality and abscisisa represents concentration of lithium chloride solution. One bloch abscissa $=0.0333 \mathrm{~N}$. 1ithiun chloride. The circles $(\bullet)$ represent velocity of fatality of individual fish. 


$$
x=
$$




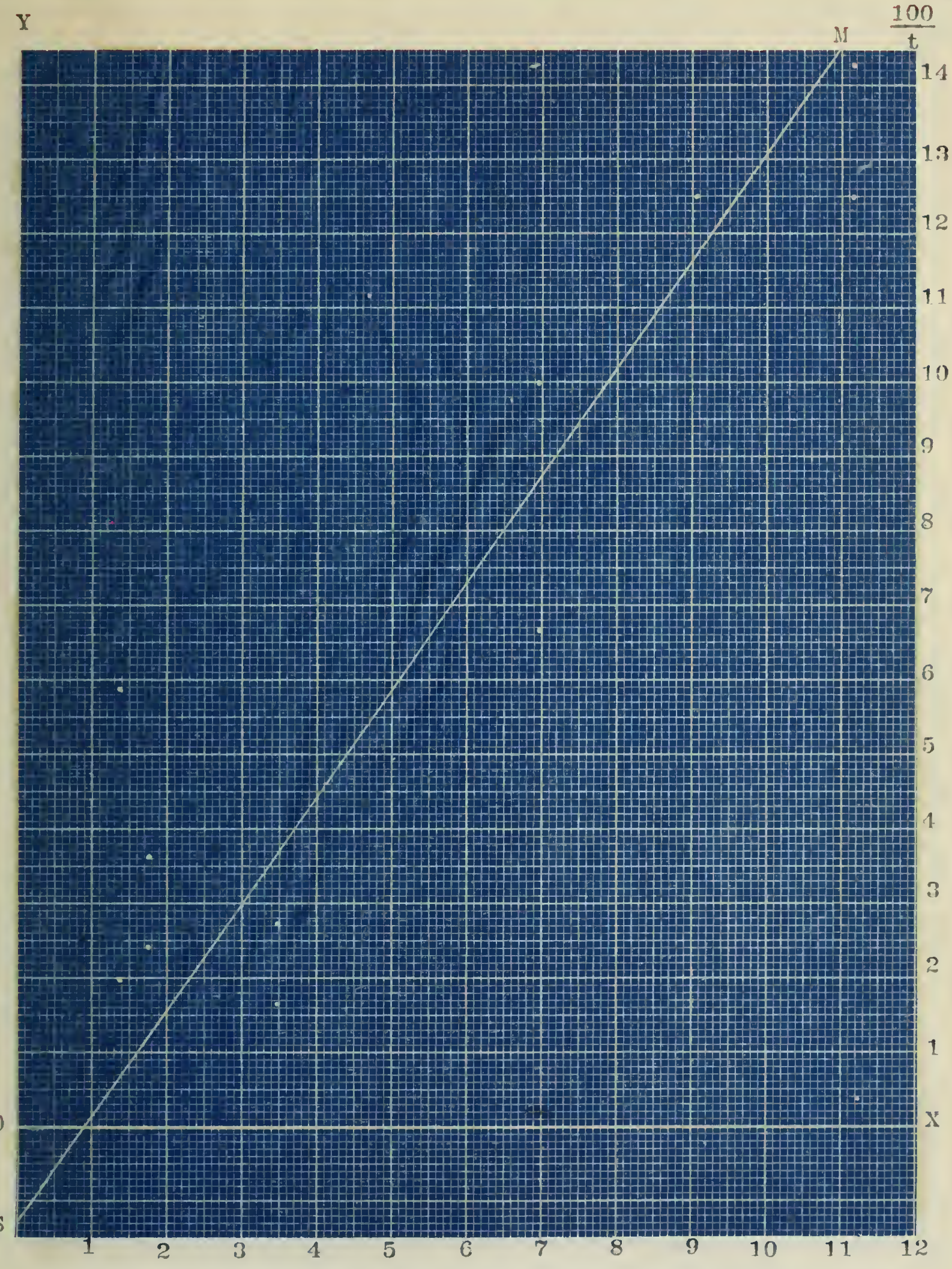

Figure 10. Graph showing the theoretical velocity of fatality curre of the goldfish when killed in lithlum chloride solution at $31.8^{\circ}$ C. Ordinate represcnts velocity of fatality and abscissa represents concentration of the lithium chloride solution. (One block abscissa $=0.0333$ iv. I1thium chlnolde. The circles (*) represent velocity of fatality of individual fish. 



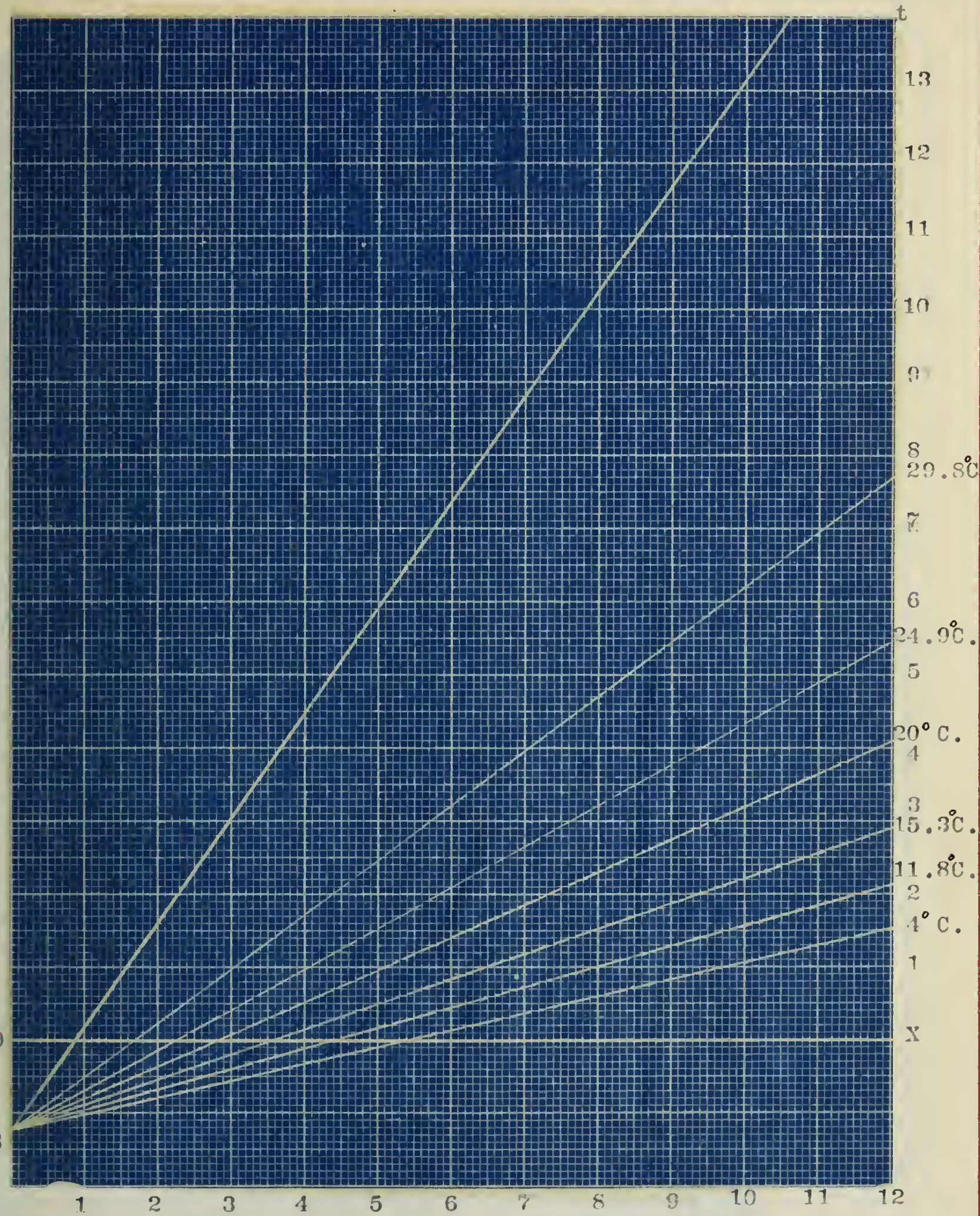

Figure 11. The theoretical relocity of fatility curves of the goldfish when killed at different temperatures in lithium chloride solution drawn for comparison. Ordinate represents velocity of ratality and abscissa represcnts concentration of the lithium chlnride solution. One block abscissa $=0.0333 \mathrm{~N}$. Iithium cliloride. 

욱

() $\infty$

$\infty$

$\infty$

10

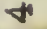

$m$

$\infty$

$r$

$\longrightarrow$ int

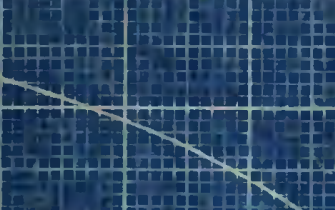





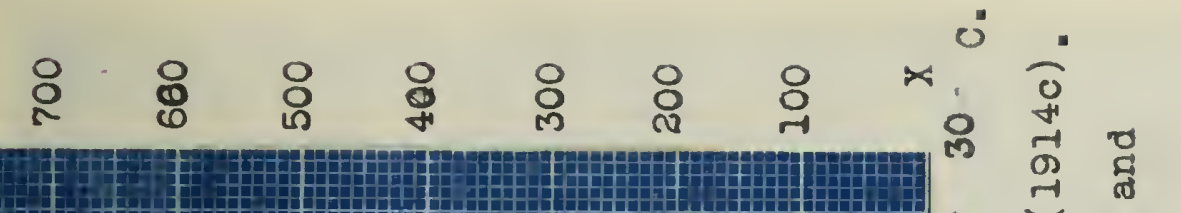

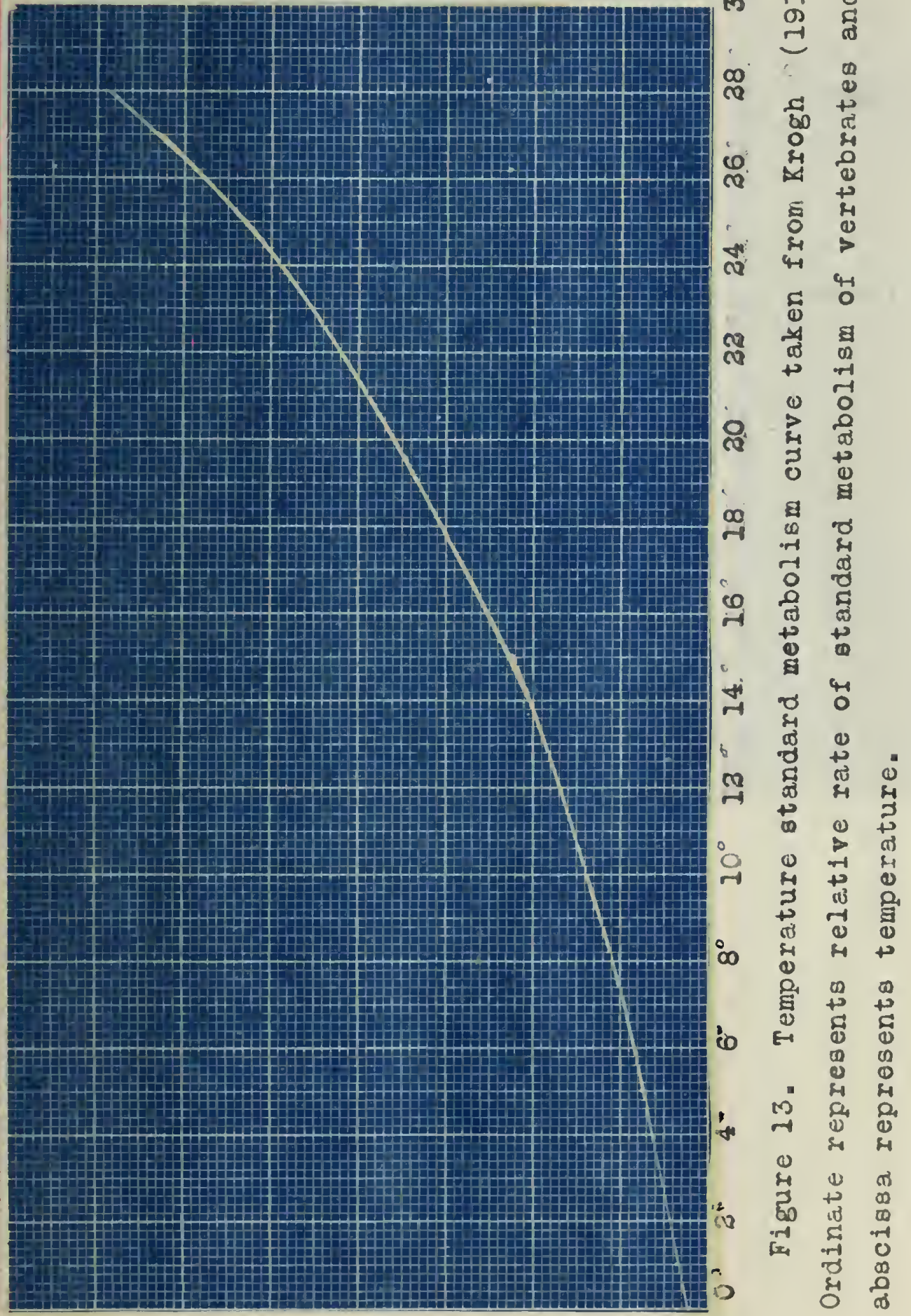



Y

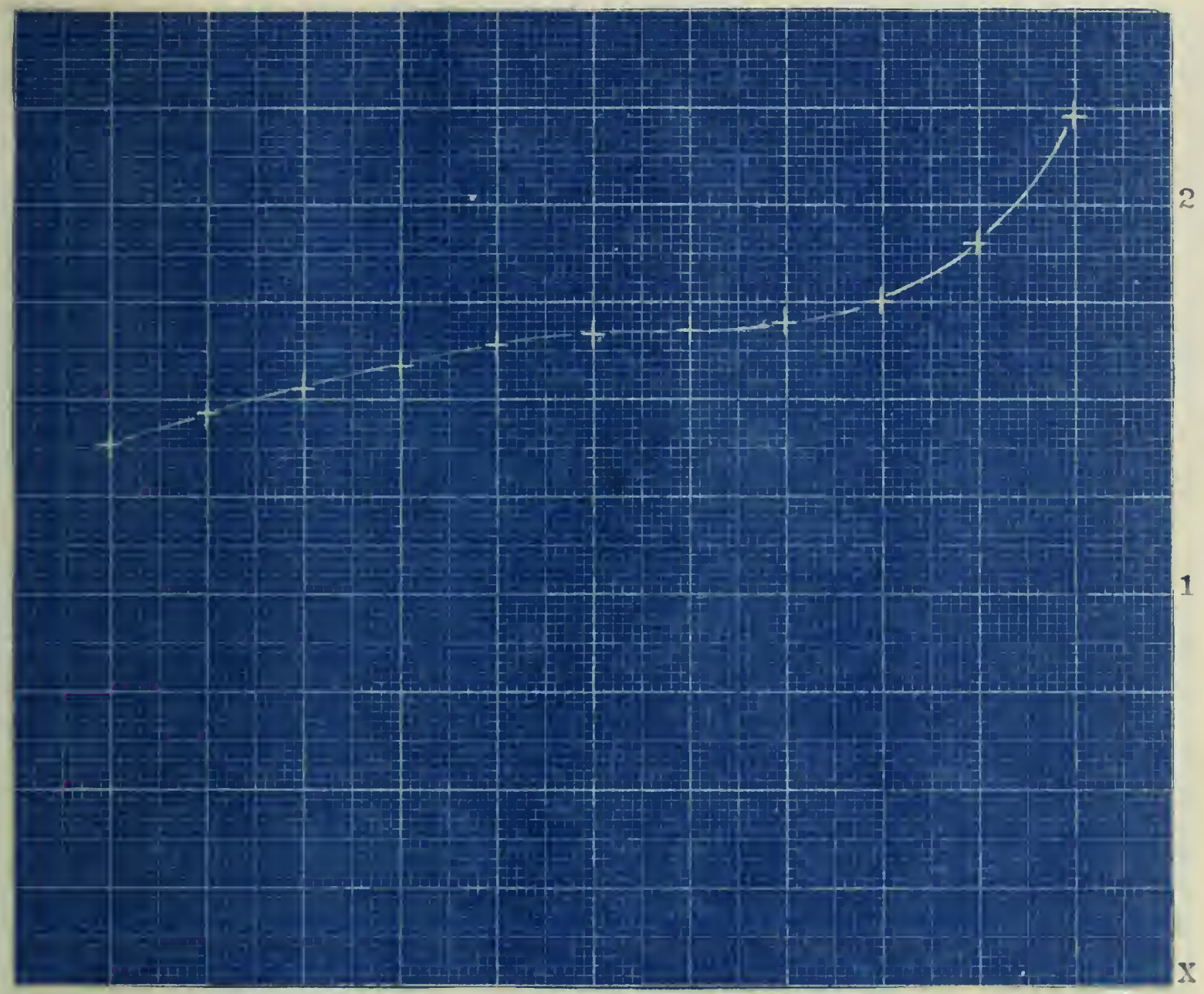

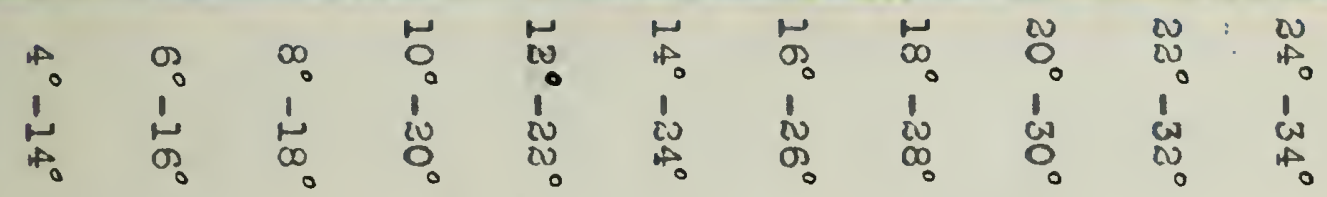

Figure 14. A graphic representation of the $Q_{10}$ for the toxicity of lithiun chloride to goldrish. Ordinate represents the ?10 and the abscissa represents the temperatures at which the $Q_{10}$ is calculated. 



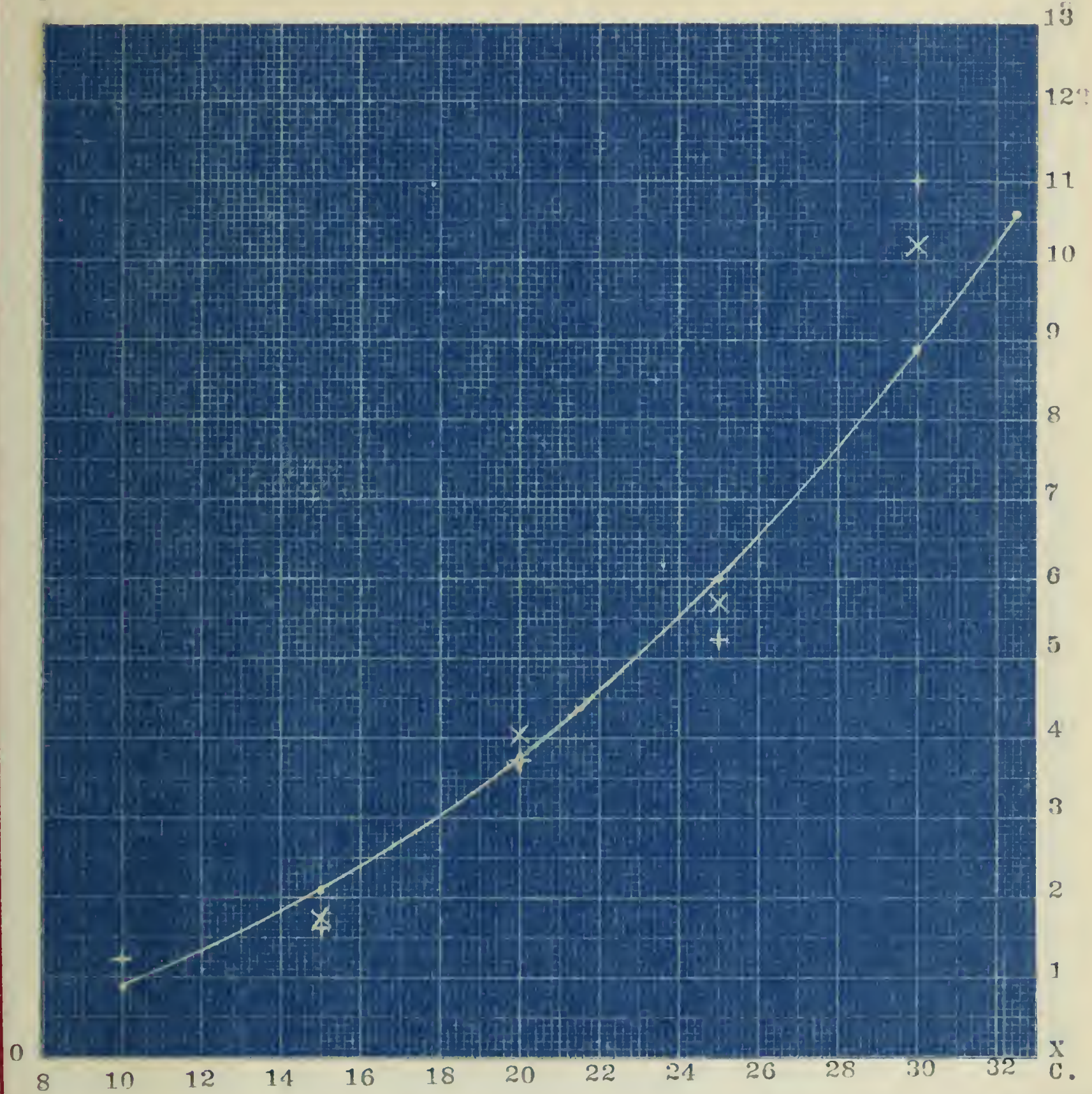

Figure 15. Graph showing temperature netabolism curve of Tenebrio molitor chrysalids. (data given by Krogh 1911c) with relative duration of life of the imago and, the relatsve total duration of life of Drosophila (data given by Loeb and Northrop 191\%). Ordinate represents relative rate of metabolisin of the renchrio chrysalidfs and the relative reciprocals of the duration of life of the imago and the total ruration of fife of Drosoplila. Ahscissa represcnts tamperature. The circles represent data of the Tenehrio chrysalias. The plus sign (t) rêpresents the rociprocal of the duration of life of the imago and the crosses ( $\boldsymbol{x}$ ) that of the total life of Drosoplila. 

Rate

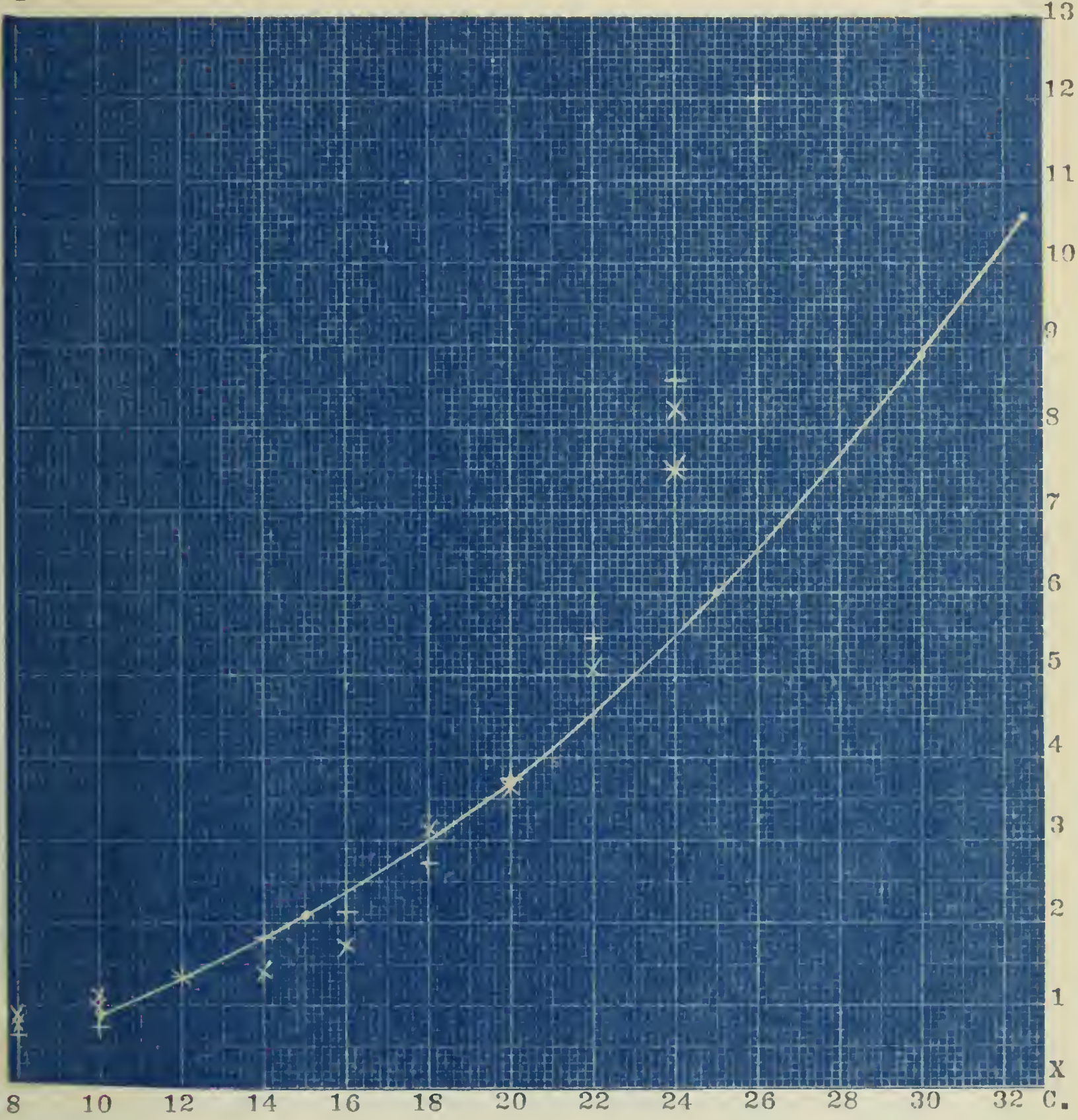

Figure 16. Graph showing temperature metablism curve of Tenebrin molitor chrysalids (data given by Krogh 1914c) with relative rate of ictivation of stirfish eggs (data given by Lillie 1917) superimposed. Ordinate represents relative rate and abscissa reprosents temperature. The circles (1) represent rolative rate of metabolism of the Tenebrio chrysalins. The plus sign (t) represcnts relative rate of activation of Group B starisli cres Table XVII and the crosses ( $X$ ) represent the relative rate of Group 1. 



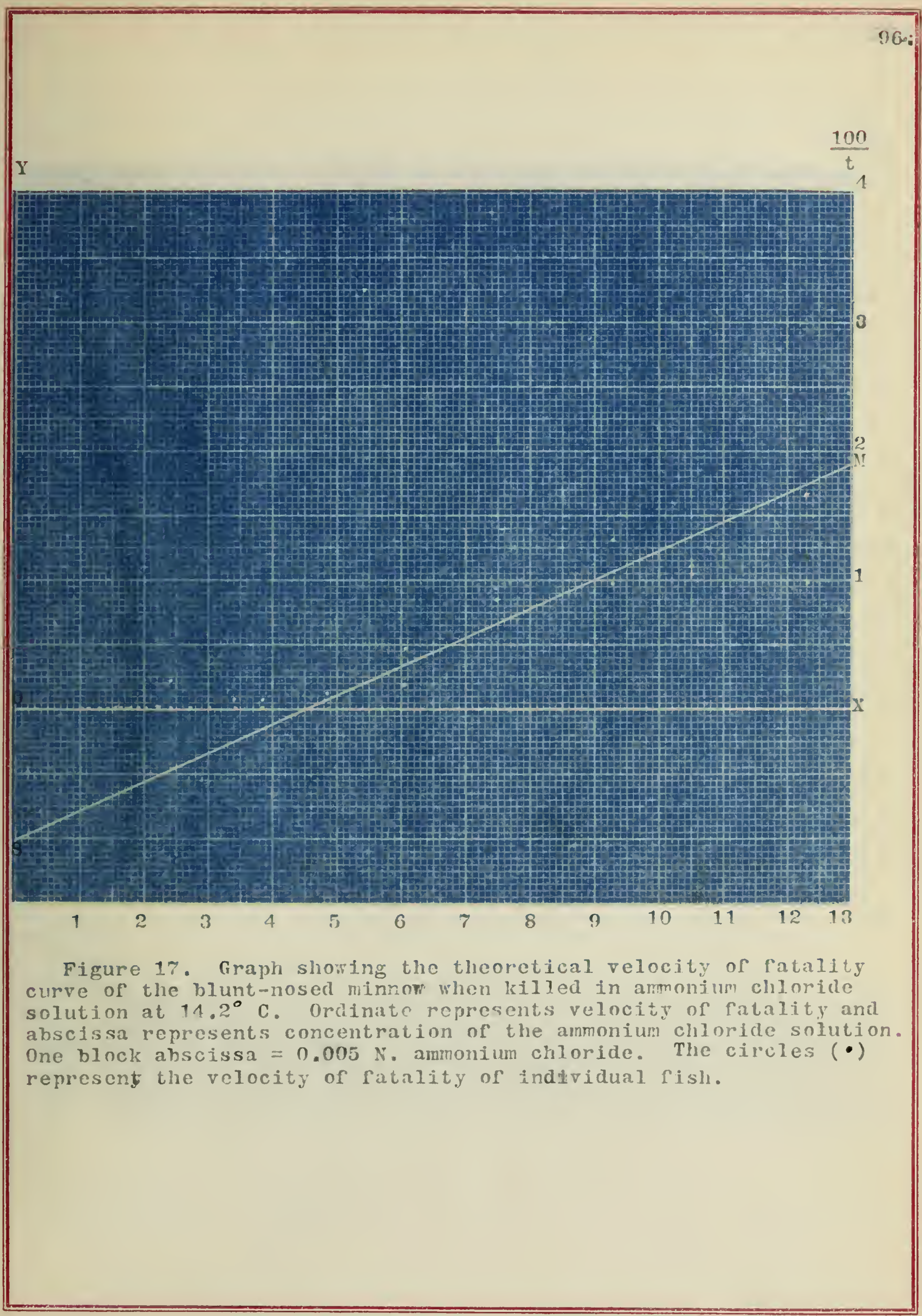





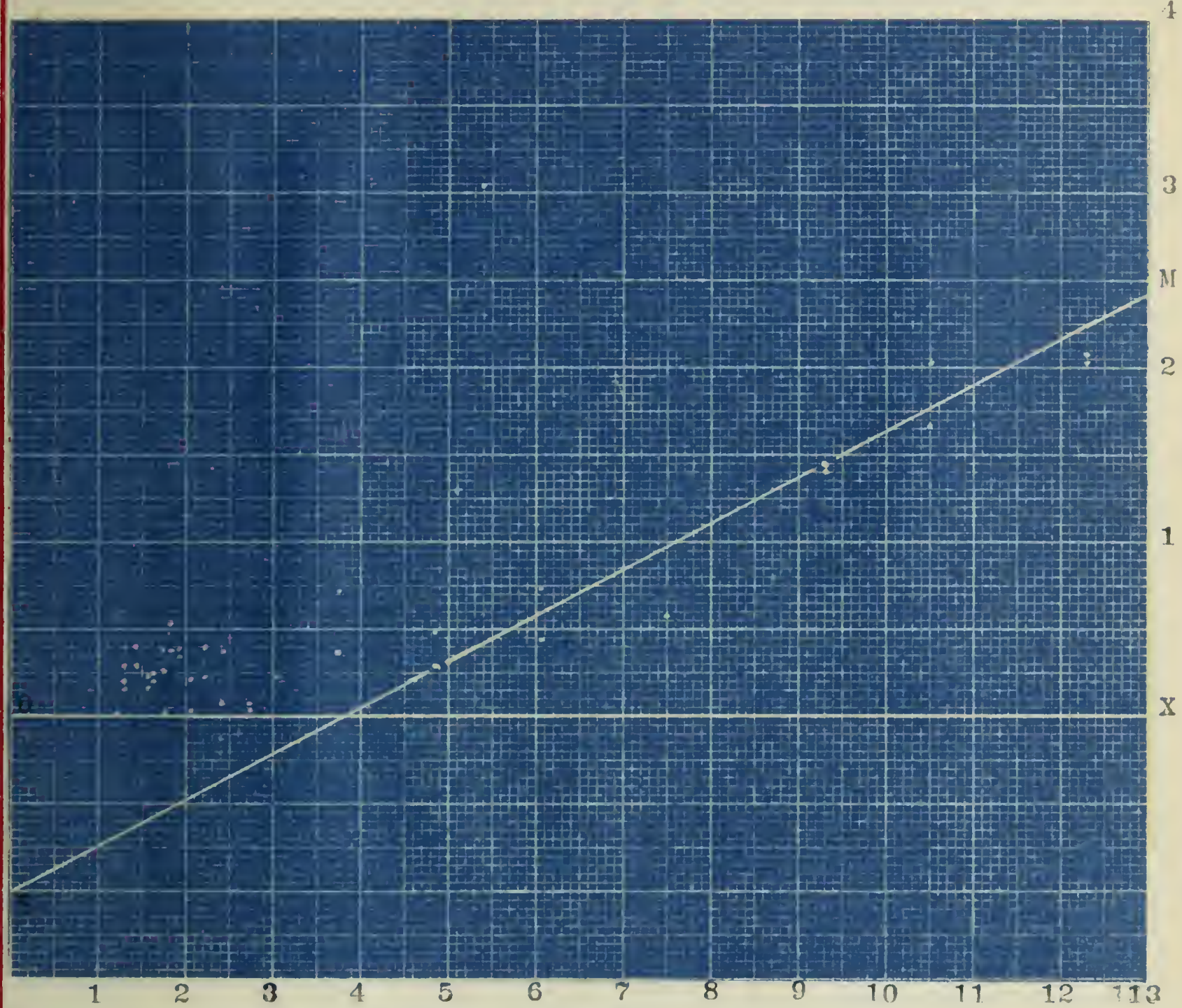

Figure 18. Graph showing the theorctical velncity of fatality curve of the blunt-nosed minnow when killed in ammonium chloride solution at $19.8^{\circ} \mathrm{C}$. Ordinate represents velocity of fatality and abscissa represents the concentration of the anmonium chlor ide solution. One block abscissa $=0.005 \mathrm{~N}$. ammonium chinrine. The circles $(\bullet)$ represent velocity of fatality of individual fish. 



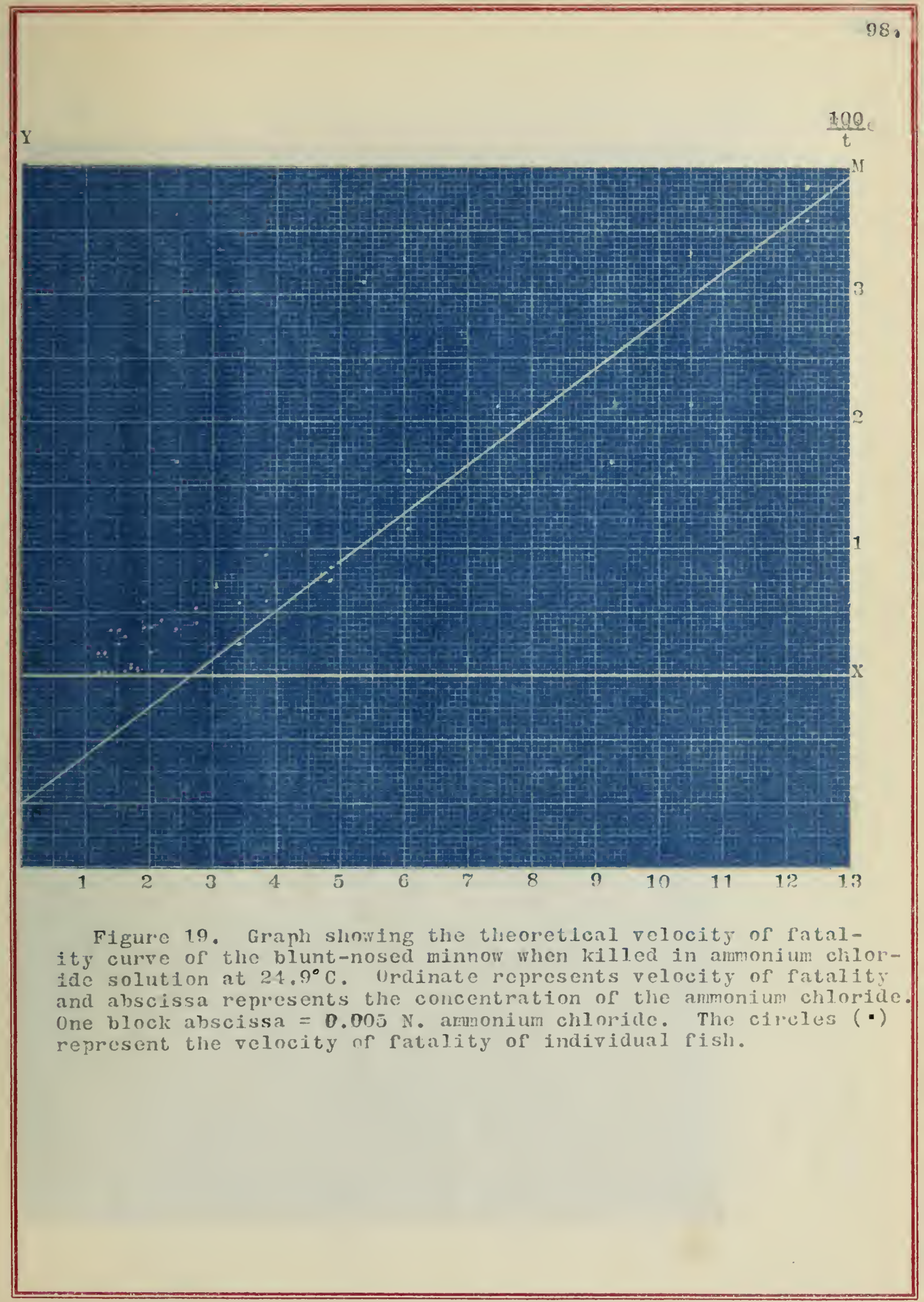



요

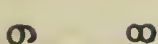

$\sim \omega$

น

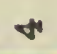

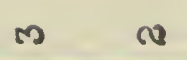

$\pi x^{0}$$$
\text { ตै }
$$
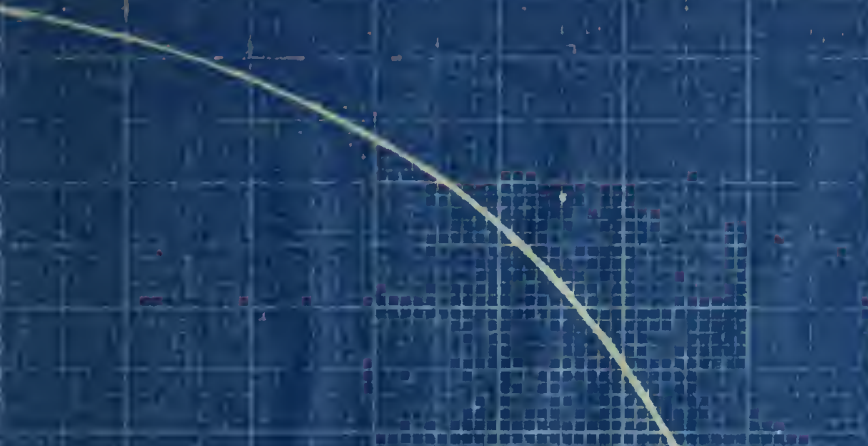



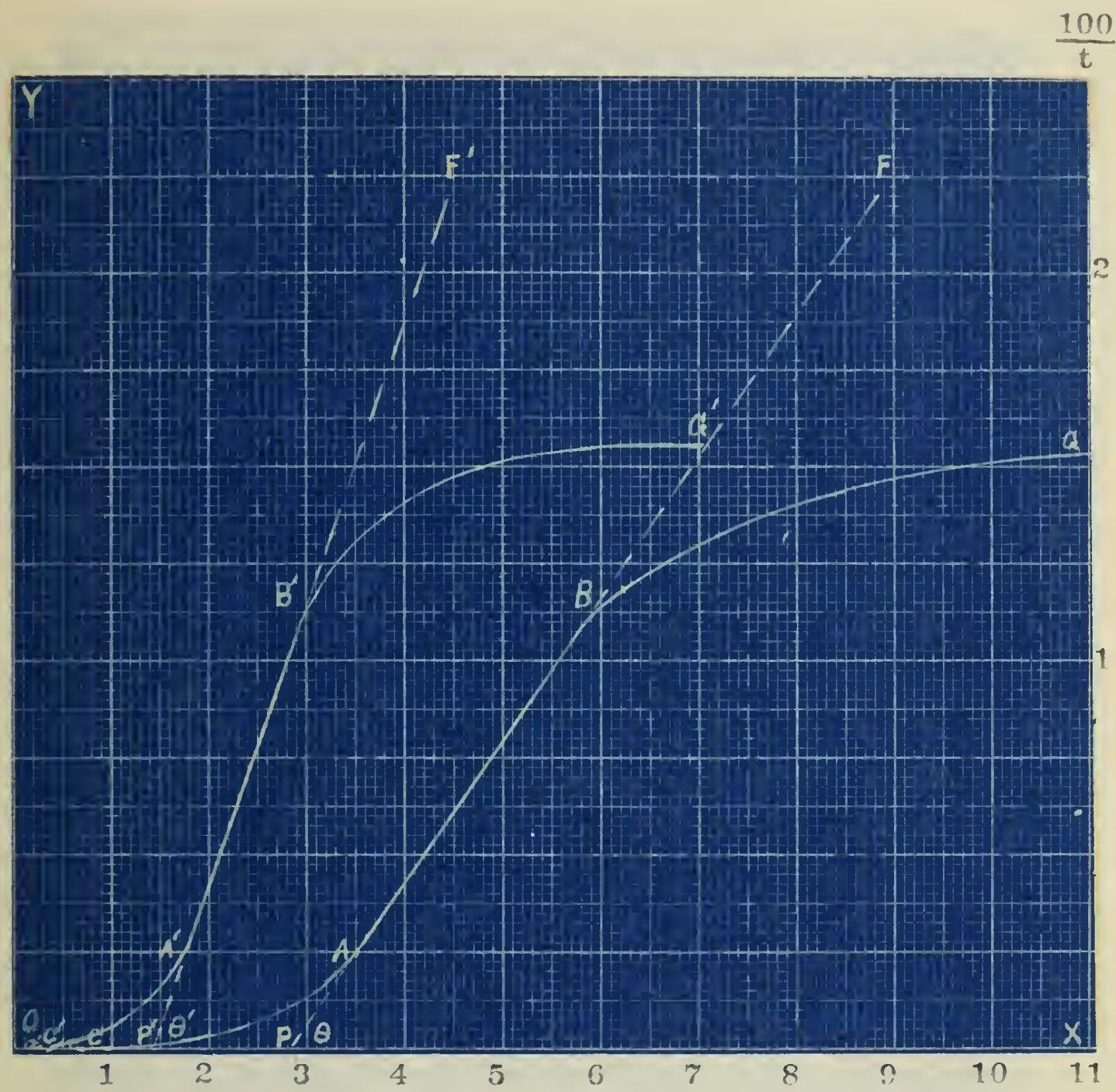

Figurc 21: Graph shows the velocity of ratality curros CiBG and $C^{\top} A^{\prime} B^{\prime} G^{\prime}$ and the theoretical velocity of fatality curves PABF and $P^{\prime} A^{\prime} B^{\prime} F^{\prime}$ of two hypothetical solutions onc harng just one half the toxic activity of the other. The two curves arc graplic represcntations of the data of experiments in which lhe blunt-nosed minnows were killed in different concentrations of ammonium chloride at $19.8^{\circ} \mathrm{C}$. Ordinate reprosents velocity of fatality. In curve $\mathrm{C} \perp \mathrm{BG}$ one block abscissa $=0.008 \mathrm{~N}$. ammonium chloride while in curve $C^{\prime} A^{\prime} B^{\prime} G^{\prime}$ one block $=0.016 \mathrm{~N}$. ammonilum chloride. 



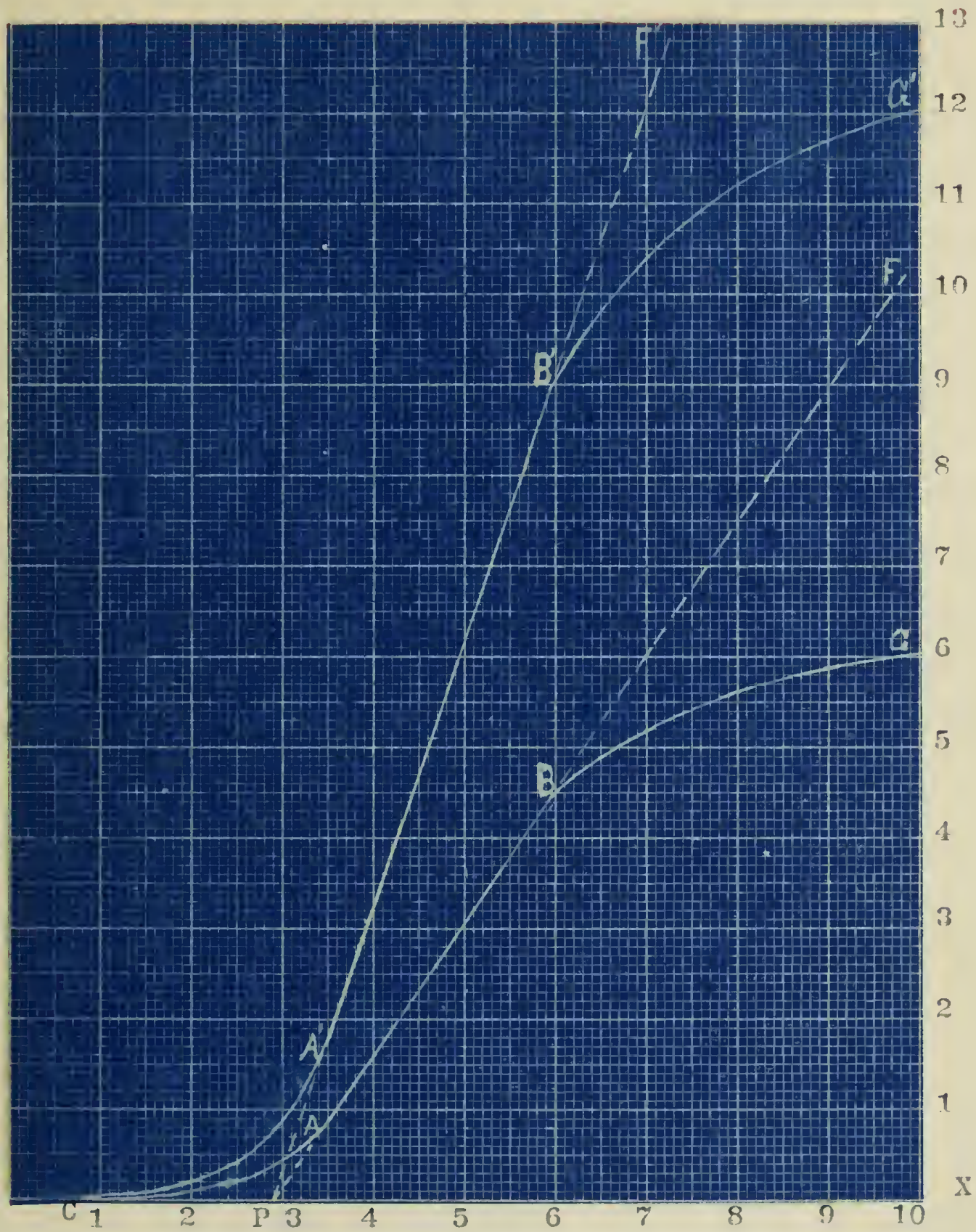

Figure 22. Graph shows the velncity of ratalits curves CABG and $C A^{\prime} B^{\prime} G^{\prime}$ of two hypothctical solutions haring the same thrcshold of toxicity concontration for fish but the velocity of ratality of the fish in one being just twice as rapid as in the other. The two curves are graphic representalions of the data of cxperiments in which the blunt-nosed minnows were killed in different concentrations of ammonium chloride at $\mathbf{1 9 . 8 ^ { \circ }} \mathrm{C}$. In botli curves one block abscissa $=0.008 \mathrm{~N}$. ammonium chloride. Four blocks ordinate $=$ one init of valocity of fatality in curre c.lBG. In curre $C N^{\prime} B^{\prime} G^{\prime}$ cighl blocks ordinate = one unit of velncity or fatality of the fish. 

Edwin Booth Powers was born at Ovilla, rexas, 1880. His preparatory work was done in the Ovilla School. In 1902 he entered Mrinity University, Waxhachie, Texas, completing his college course and taking the A.B. degree in 1906. He spent the summer of 1905 at the University of Chicggo as an undergraduate. The second and third year of his undergraduate course he vas Assistant in Chemistry and the fourth yeer Assistant in Biology. During the year 1906-1907 he was teacher of science in the Terrell High School, l'errell, Texas. In the year 1907-1908 he was Principal of the Ovilla School at Ovilla, Texas. He was Instructor of Biology at Irinity University 1908-1910 and Professor of Biology 1910-1915 with leave for 1912-1913. The summers of 1908, 1910, 1913, and 1915, the last term of the sumer of 1914, and the vear 1912-1913 were spent at the University of Chicago as graduate student and he took his A. W. degree at that institution in June of 1913. During the most of his stay at the University of Chiçgo he held a scolarship and was Assistant in Zoology during the summer of 1913 and 1915. During the sumner of 1915 he was Research Assistant in "joology at the Puget Sound Biological station. He spent the years 1915-1918 as graduate student in the University of Illinois. The irirst year he waw Assistant in Zoology and the second year he vas a Fellov in Pharmaceutical Research. During the summer of 1917 he was Fntomological Assistant in the IIlinois State Viatural History Survey. During the academic jear 1915-1916 he was elected to Sigman Xi. During the period of his graduate study he published the following papers:- 

The Reactions of Crayfishes to Gradients of Dissolved Carbon Dioxide and Acetic and Hydrochloric Acids. Biol. Bull., 27: $177-200,1914$.

An Experimental Study of the Movements of Herring and Other flarine Fishos. Biol. Bull., 28:315-334, 1915. (By Victor L. Shelford and Edwin B. Powers.)

A Collecting Bottle especially adapted for the Quantitative and Qualitative Determination of Dissolved Gases, particularly very small quantities of Oxygen. Bull. IIl. State Iab. Nat. Hist., Vol. II, Article 10, 1918.

The Goldfish (Carassius carassius L.) as a test Animal in the Study of Toxicity. Ill. Biol. Mon., Vol. 4, No. 2, 1918. 



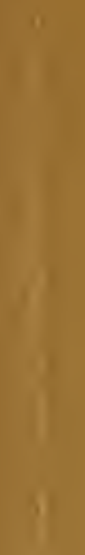

1
1
1

I

I

$=$

I

f

$=$

3 
